University of Nebraska - Lincoln

DigitalCommons@University of Nebraska - Lincoln

US Army Research

U.S. Department of Defense

2015

Evaluating the validity and applicable domain of the toxic load model: Impact of concentration vs. time profile on inhalation lethality of hydrogen cyanide

Lisa M. Sweeney

Naval Medical Research Unit Dayton, lisa.sweeney.3.ctr@us.af.mil

Douglas R. Summerville

U.S. Army Edgewood Chemical Biological Center

Stephen R. Channel

Leidos

Brian C. Sharits

CAMRIS

Nathan M. Gargas

CAMRIS

See next page for additional authors

Follow this and additional works at: http://digitalcommons.unl.edu/usarmyresearch

Sweeney, Lisa M.; Summerville, Douglas R.; Channel, Stephen R.; Sharits, Brian C.; Gargas, Nathan M.; and Gut Jr., Chester P., "Evaluating the validity and applicable domain of the toxic load model: Impact of concentration vs. time profile on inhalation lethality of hydrogen cyanide" (2015). US Army Research. 317.

http://digitalcommons.unl.edu/usarmyresearch/317

This Article is brought to you for free and open access by the U.S. Department of Defense at DigitalCommons@University of Nebraska - Lincoln. It has been accepted for inclusion in US Army Research by an authorized administrator of DigitalCommons@University of Nebraska - Lincoln. 
Authors

Lisa M. Sweeney, Douglas R. Summerville, Stephen R. Channel, Brian C. Sharits, Nathan M. Gargas, and Chester P. Gut Jr. 


\title{
Evaluating the validity and applicable domain of the toxic load model: Impact of concentration vs. time profile on inhalation lethality of hydrogen cyanide
}

\author{
Lisa M. Sweeney ${ }^{\mathrm{a}, *}$, Douglas R. Sommerville ${ }^{\mathrm{b}}$, Stephen R. Channel ${ }^{\mathrm{c}}$, Brian C. Sharits ${ }^{\mathrm{d}}$, Nathan M. Gargas ${ }^{\mathrm{d}}$, \\ Chester P. Gut Jr. ${ }^{\mathrm{d}}$ \\ ${ }^{a}$ Henry M. Jackson Foundation for the Advancement of Military Medicine, Naval Medical Research Unit Dayton, Wright Patterson Air Force Base, OH 45433, United States \\ ${ }^{\mathrm{b}}$ U.S. Army Edgewood Chemical Biological Center, Aberdeen Proving Ground, MD 21010, United States \\ ${ }^{c}$ Leidos, Linton, IN 47441, United States \\ ${ }^{\mathrm{d}}$ CAMRIS, Naval Medical Research Unit Dayton, Wright Patterson Air Force Base, $\mathrm{OH} 45433$, United States
}

\section{A R T I C L E I N F O}

\section{Article history:}

Received 14 July 2014

Available online 23 February 2015

\section{Keywords:}

Hydrogen cyanide

Nose-only inhalation

Acute lethality

Non-constant concentrations

Pulsed exposures

Toxic load model

\begin{abstract}
A B S T R A C T
The ten Berge model (or "toxic load" model) is often used to estimate the acute toxicity for varying combinations of inhaled concentration and duration. Expressed as $C^{n} \times t=$ toxic load (TL), TLs are assumed constant for various combinations of concentration $(C)$ and time $(t)$. Experimental data in a recent acute inhalation study of rats exposed to time-varying concentrations of hydrogen cyanide (HCN) supported the validity of the toxic load model except under very brief, discontinuous, high concentration exposures. In the present investigation, experiments were conducted to extend the evaluation of the applicable domain of the model for acute lethality of HCN in the rat (cumulative exposure range of 2900$11,000 \mathrm{ppm} \mathrm{min}$ ). The lethality of HCN over very short ( $<5 \mathrm{~min}$ ) durations of high concentrations did not conform to the toxic load model. A value of $n=1.57$ was determined for uninterrupted exposures $\geqslant 5 \mathrm{~min}$. For 30 -min exposures, the presence or absence of a gap between two exposure pulses of different concentrations, the relative duration, relative height, and the ordering of the pulses (low then high, vs. high then low) did not appear to have a meaningful impact on the toxic load required for median lethality.
\end{abstract}

(c) 2015 Elsevier Inc. All rights reserved.

\section{Introduction}

To address the need to estimate the acute toxicity of vapors and gases of potentially exposed individuals for varying combinations of concentration and duration, the ten Berge model (ten Berge and van Heemst, 1983; ten Berge et al., 1986), also known as the toxic load model (Ride, 1995; Sommerville et al., 2006), is often used. The ten Berge/toxic load model is expressed as $C^{n} \times t=k$, where " $n$ ", the toxic load exponent, and " $k$ ", the toxic load, are constant for various combinations of concentration $(C)$ and time $(t)$. These parameters, $n$ and $k$, are typically derived from toxicity studies where animals were exposed to different concentrations of test chemicals for specified exposure durations. When $n=1$, this equation simplifies to $C \times t=k$ and is known as Haber's Rule (Haber, 1924; Witschi, 1999). The toxic load model is used in the U.S. for

\footnotetext{
* Corresponding author. Fax: +19379049412.

E-mail addresses: lisa.sweeney.3.ctr@us.af.mil, Imsweeney@aol.com (L.M. Sweeney).
}

military operational risk assessments (Department of Defense, 2005; Sommerville et al., 2010) that inform strategic planning for response actions and in civilian applications such as the development of Acute Exposure Guidelines (National Research Council, 2001). Tabulated values for $n$ and $k$ are available for a wide range of chemicals and endpoints from multiple sources (Health and Safety Executive, 2015; Mannan, 2005).

A theoretical basis for the toxic load model and its extension from the constant-concentration exposures typically found in the laboratory to the time-varying exposures encountered in a typical release scenario has had limited development until relatively recently (Rhomberg, 2009; Kaplan, 2009; Pauluhn, 2015), perhaps in part due to the paucity of relevant experimental data that could be used to test such theories. Because no experimental studies had systematically investigated acute toxicity under nonconstant concentration vs. time profiles, a case study was conducted using hydrogen cyanide $(\mathrm{HCN})$ as the test chemical and acute lethality in rats as the endpoint (Sweeney et al., 2014). In that study, rats were exposed to either constant concentrations of $\mathrm{HCN}$ or 
experienced "pulsed" exposures consisting of two different concentrations of HCN (2:1 or $5: 1$ ratio), with or without a "gap" between pulses (30\% of the total exposure duration), with a total duration (exposure plus gap, if applicable) of 5 or $30 \mathrm{~min}$. Most of the tested scenarios (6/8) were found to conform to the toxicity expected based on the toxic load model; the two exceptions were very brief, high concentration, discontinuous exposures (exposures with "gaps") where higher-than expected HCN concentrations were required to produce equivalent lethality. If the recovery time afforded by the gap was protective in a short (5-min) exposure, it would be expected to be protective in a longer exposure as well (30 min) but was not. We speculated that during very brief pulses (1.75 min), some rats were able to reduce their systemic exposure via breath-holding, an adaptation that could not be sustained during longer exposure durations. Despite the extensive application of the toxic load/ten Berge model, the findings of Sweeney et al. (2014) provide the first known experimental support for the model under non-constant concentration exposure conditions. The applicability of these findings to other chemicals is unknown, but is most likely to hold for other compounds that act by similar modes of action or on similar time scales.

In the present investigation, additional experiments were designed and conducted to extend the evaluation of the applicable domain of the toxic load model for the case of acute lethality of $\mathrm{HCN}$ in the rat. Additional concentration vs. time profiles were evaluated to clarify the toxicity of brief exposures and to determine if the order (high-then-low, vs. low-then-high) or the relative durations of the pulses has an impact on lethality.

\section{Materials and methods}

\subsection{Selection of test chemical}

The current experiments and analyses build on previous efforts described in Sweeney et al. (2014). The aim of both the current and previous work was to test the validity of the toxic load model by means of a case study or series of case studies rather than being driven by a desire to understand the test chemical itself. HCN was selected as the test chemical largely due to the necessity to select a chemical, species (rat), and endpoint (lethality) for which the toxic load exponent was known to differ from 1 (Department of Defense, 2005; National Research Council, 2002). The ability to readily and consistently generate the targeted vapor concentrations was considered advantageous from the standpoint of experimental logistics. HCN also demonstrates consistent toxicity among species, binding to cytochrome oxidase and thereby reversibly preventing oxygen utilization in sensitive tissues such as the brain (National Research Council, 2002, 2008).

\subsection{Overview of experimental design}

Laboratory rats were exposed to an atmosphere containing $\mathrm{HCN}$ using a nose-only exposure system. A variety of $C \times t$ profiles were generated in order to discern the impact (or lack thereof) of the following factors on HCN lethality: constant concentration exposure vs. variable concentration exposure (i.e., two pulses with different concentrations), the ordering of the height of the two pulses, the relative widths of the pulses, the presence or absence of a gap between the two pulses, and the total duration of the test (exposure durations plus gap). The height ordering was reversed from what was tested in a prior series of exposures (high concentration followed by low concentration in Sweeney et al., 2014). Conflicting findings on the importance of a "gap" were previously identified in 5-min vs. 30-min exposures, so an intermediate exposure duration (10-min) was tested in this series. Relative pulse duration was also varied to test the toxic load model under an additional parameter and to create more realistic $C \times t$ profiles.

Three baseline (conventional) profiles as well as 8 non-constant (nonconventional) exposure profiles were chosen to further investigate the applicable domain of the toxic load model, with respect to acute HCN lethality in rats. A total of 60 trials were conducted (10 rats per trial). The baseline profiles consisted of exposures of $2.33,10$, or $30 \mathrm{~min}$ in duration to a constant concentration of $\mathrm{HCN}$. The non-constant test profiles were 10 or $30 \mathrm{~min}$ in duration, with either two pulses of equal duration or two pulses at a duration ratio of $1: 2$. Pulse 2 concentrations were set at a fixed multiple of the initial concentration (5-fold higher). Gaps between pulses were either $0 \mathrm{~min}$ (no gap) or 30\% of the total duration (i.e., $3 \mathrm{~min}$ or $9 \mathrm{~min})$. The $C \times t$ profiles for this series are depicted in Fig. 1.

As in Sweeney et al. (2014), the study design (Fig. 1) consisted of baseline exposures (no change in concentration over time) (Profiles 1, 6, and 11) and the investigation of three tested factors affecting the shape of the $C \times t$ profile using a factorial design (Profiles $2-5$ and 7-10). The current Profiles 8 and 10 provide mirror images to exposures conducted in Phase 1 (Phase 1 Profiles 8 and 10 , respectively), facilitating a direct comparison of low-high vs. high-low ordering on pulse height. For each profile, with the exception of Profile 6, at least 4 exposure concentrations were tested (see Appendix A), which included trials approximating the median lethal concentration $\left(\mathrm{LC}_{50}\right)$ plus additional concentrations selected to provide coverage of a dose-response range, ideally with response rates neither $0 \%$ nor $100 \%$.

\subsection{Animal exposures and monitoring}

The animal protocol was approved by the Wright-Patterson Air Force Base (WPAFB) Institutional Animal Care and Use Committee and the Air Force Surgeon General's office. A total of 600 male Sprague-Dawley (Rattus norvegicus) rats [Crl:CD(SD) BR rats], 56 weeks old, were purchased from Charles River Laboratories (Wilmington, MA). Rats were maintained in an animal facility approved by the Association for Assessment and Accreditation of Laboratory Animal Care International, pair housed prior to exposure, and provided husbandry in accordance with the National Research Council's Guide for the Care and Use of Laboratory Animals. Food and water were made available for all animals ad libitum during periods of non-exposure. Rats were quarantined and acclimated to the facility for 10 days. During quarantine and acclimation periods the rats were pair housed. Following release from quarantine, all animals were weighed. This weight was used to sort the rats to their prospective exposure group (10 rats per exposure). For a given shipment (lot number) of animals, the heaviest were assigned to the first exposure group, followed by the next heaviest animals to the second exposure group, and so on so that differences in weight among groups tested over a time span of up to 4 days would be minimized. The lightest animals from a given shipment were assigned to the final exposure groups. When more than one exposure was planned for a single study day, the animals were redistributed evenly by weight among the two or three exposures for that day. Due to the span of time over which the exposures were to be carried out, animals were ordered in batches (each batch corresponded to 1 week of testing) so that the animals were similar in age and weight at exposure. The sorting process and multiple batches yielded consistent body weights throughout the study.

Animals were exposed 1 time via nose-only inhalation (described below). Acclimation to the nose-only tubes was not done prior to the exposure day, due to the short duration of the exposures (a single 2.33-30 min exposure). Tube acclimation on the exposure day involved placing each of the animals in an open 
Profile 1

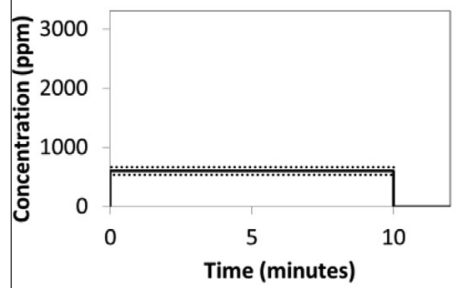

Profile 3

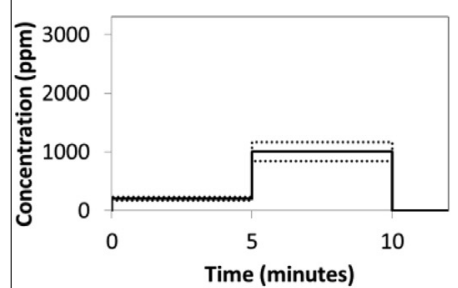

Profile 5

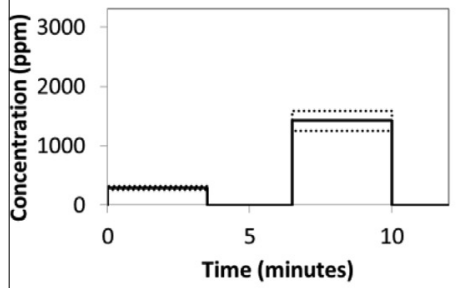

Profile 7

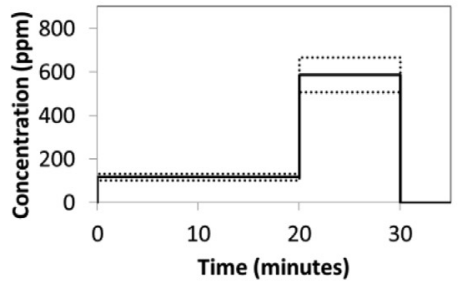

Profile 9

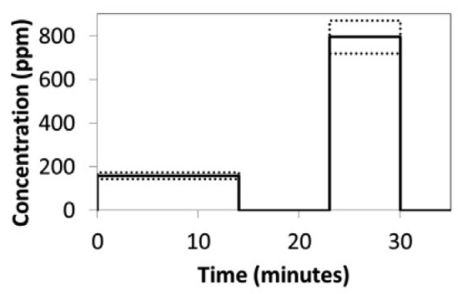

Profile 11

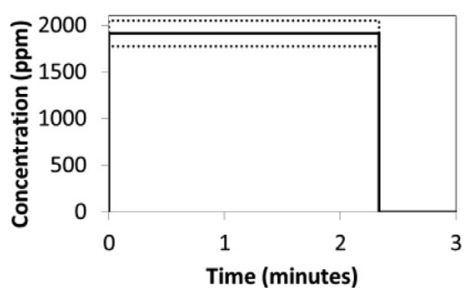

Profile 2

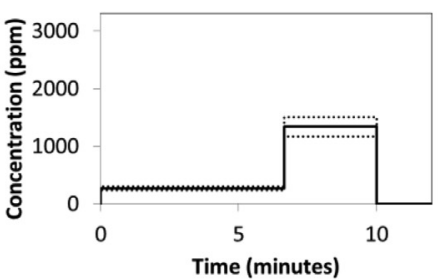

Profile 4

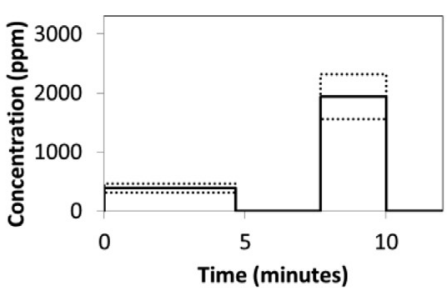

Profile 6

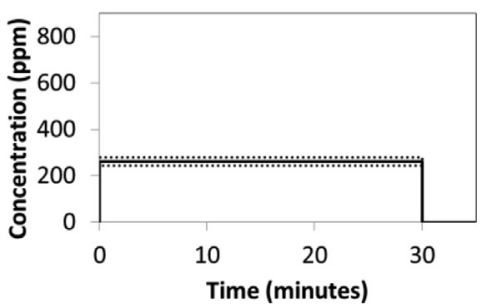

Profile 8

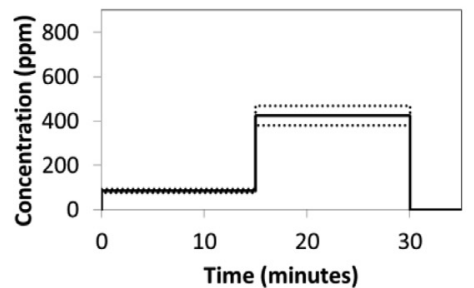

Profile 10

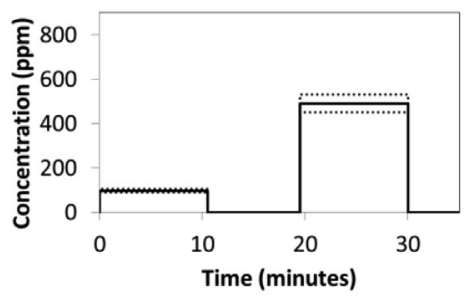

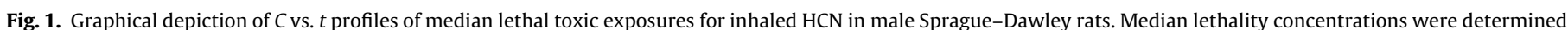
by benchmark dose analysis of 4-9 different exposures of 10 rats per profile (Table 3 ).

nose-only tube on a laboratory counter top for $30 \mathrm{~min}$ prior to the initiation of $\mathrm{HCN}$ exposures. Time of death and appearance of severe effects were monitored and recorded when possible during exposure, for $1 \mathrm{~h}$ following exposure, and during a 24-h postexposure observation period. Following exposure, rats were singly housed to facilitate observations in the post-exposure observation 
period. Surviving animals were returned to the Vivarium after exposures and a 1 -h post-exposure observation period. Rats surviving the exposures were periodically monitored (twice daily) by vivarium staff and by study staff at approximately $24 \mathrm{~h}$ postexposure. After the $24 \mathrm{~h}$ observation period, surviving rats were euthanized by carbon dioxide inhalation followed by decapitation using a guillotine.

\subsection{Test chemical}

The rats were exposed to a mix of HCN with $21 \%$ oxygen, balance nitrogen from a cylinder diluted by clean breathing air to attain the desired concentration. The dilution and clean control air for the exposure system was supplied by an air compressor and filtered for oils, organics, and particulates by a compressed breathing air purification system (Model No.: RP050, MST ${ }^{\circledR}$ Inc., Hicksville, $\mathrm{OH}$ ). Five cylinders of HCN/oxygen/nitrogen mix exposure gas manufactured by Custom Gas Solutions (Durham, NC) were obtained from Weiler Welding (Moraine, $\mathrm{OH}$ ); one at 1000 ppm, two at 2000 ppm, and two at 5000 ppm HCN concentration. All of the gas cylinders came with an analytical report that certified the concentrations of the gases to within $\pm 2 \%$ with the gravimetric method of analysis.

\subsection{Exposure system, test atmosphere generation, and monitoring}

Animals were exposed using a single 12-position Cannon style nose-only exposure unit (constructed in house) which was previously described (Sweeney et al., 2013, 2014). Briefly, in order to produce a clean air gap in the exposure, two parallel dilution systems were used. Each dilution system was capable of being turned on or off independently from the other. Temperature, humidity, and static pressure were monitored in the vented hood containing the nose-only exposure unit. To the extent possible, the temperature was maintained between 68 and $79^{\circ} \mathrm{F}\left(20\right.$ and $\left.26^{\circ} \mathrm{C}\right)$ and the relative humidity was maintained between $30 \%$ and $70 \%$. The concentration of the HCN gas was measured with a Nicolet 380 Fourier Transform Infrared Spectrometer (FT-IR) (Thermo Fisher Scientific Inc., Waltham, MA) tuned to a peak at $3339.5 \mathrm{~cm}^{-1}(2994.5 \mathrm{~nm})$. The FT-IR sampled prior to the nose-only exposure unit at $0.5 \mathrm{~L} / \mathrm{min}$ from a total system flow of $6.5 \mathrm{~L} / \mathrm{min}$. The FT-IR sampling in this location prevented interference from moisture, exhaled gasses, and other contaminants. The FT-IR was zeroed on breathing air at the beginning of each study day. The FT-IR calibration curve of $y=20511 x^{2}+3492 x$ was constructed using seven gas concentrations ranging from 0 to $5000 \mathrm{ppm} \mathrm{HCN}$. The resulting curve had an $R^{2}$ of 0.9997 . The uniformity of distribution was determined by measuring the total port distribution (variability of 7 ports), the temporal distribution (variability within a single port) and calculating the spatial distribution (variability between ports). All coefficients of variations were less than $1 \%$. The average flow rate for the system was $6.49 \mathrm{~L} / \mathrm{min}$ with a minimum of $6.32 \mathrm{~L} / \mathrm{min}$ and a maximum of $6.50 \mathrm{~L} / \mathrm{min}$. The average flow rate through the nose-only exposure unit was $6.0 \mathrm{~L} / \mathrm{min}$ with a $t 95 \%$ of $10.5 \mathrm{~s}$.

\subsection{Study day}

A study day was defined as the exposure period from approximately 8:15 am until 12:00 pm. The animals, pair housed in their polycarbonate domiciliary cages on a rack, were delivered from the Vivarium via a closed box delivery truck to the exposure laboratory around 8:15 am to 8:30 am. After arrival, all animals were weighed and the first group was loaded into the nose-only tubes. All other animals were loaded at approximately $30 \mathrm{~min}$ prior to their intended exposure time. The period following the exposures was used to unload animals from the nose only tubes and return each animal (singly housed) to a domiciliary cage where food and water were available ad libitum. No food or water was available during the exposure. Exposure groups (1-3 per day) were numbered consecutively from 1 to 60 . The exposures were conducted from June 3 through July 2, 2013, from July 29 through 31 July, 2013, and from August 26 through August 29, 2013.

\subsection{Selection of exposure concentrations}

The first exposures were conducted as single pulses for 2.33 or 10 min (i.e., Profiles 11 and 1, respectively) at target concentrations approximating estimated $\mathrm{LC}_{50}$ values for young adult male Sprague-Dawley rats exposed to $\mathrm{HCN}$, as predicted from previous 5- , 15- and 30-min results in this laboratory (Sweeney et al., 2014). The number of deaths for the 10-min exposure was in the anticipated range, but no exposure-related deaths were observed for the $2.33 \mathrm{~min}$ exposure; concentrations in subsequent 2.33min exposures were increased so that the dose-response relationship could be adequately characterized. In general, initial test concentrations for the other exposure profiles were selected to yield $\sim 50 \%$ lethality based on findings from previous exposures of the same total duration. Additional target concentrations for a previously-tested profile were derived using expert judgment, taking into consideration the observed steepness of the dose response across profiles, previous results for the profile in question, and the desired spacing of responses across the dose-response continuum for the profile in question. Because Profile 6 had previously been tested, a limited testing regimen (two exposure trials only) was conducted to confirm the similarity of HCN toxicity between rats bred $\sim 1$ year apart; this confirmation was deemed necessary because the previous HCN lethality results in this laboratory had differed from those in the literature (Sweeney et al., 2014).

\subsection{Dose-response analysis}

In order to derive the best estimates of dose (concentration $\times$ time) producing $20 \%$ and $50 \%$ lethal responses $\left(\mathrm{LCt}_{20}\right.$ and $\mathrm{LCt}_{50}$ ), results for each profile (Appendix A) were evaluated using the U.S. Environmental Protection Agency's (U.S. EPA) Benchmark Dose Software (BMDS, version 2.2.0) with the BMDS Wizard (version 1.6.1, ICF International, Durham, NC). Dose was expressed as $C_{\mathrm{avg}} \times t($ in $\mathrm{ppm} \times \mathrm{min})$. The dose for all the animals in a single trial was computed using the total exposure time regardless of the estimated time of death, consistent with the derivation populationlevel outcomes. The following dichotomous dose-response models were tested: Logistic, LogLogistic, Probit, LogProbit, Weibull, Quantal-Linear, Multistage, Gamma, and Dichotomous-Hill. In all cases, a background response rate of zero was assumed. Outputs from the dose-response analysis included a graphical presentation of the dose-response relationship, an estimate of the goodness-offit, the best estimate of the dose (concentration $\times$ time) producing a $50 \%$ lethal response $\left(\mathrm{LCt}_{50}\right)$, the 97.5 th percent lower confidence limit on the $\mathrm{LCt}_{50}\left(\mathrm{LCt}_{50 \mathrm{LCL}}\right)$, and standardized residual errors. $\mathrm{A}$ value for the upper confidence limit is not provided by the BMDS. Thus, the upper limit was estimated by assuming that the uncertainty distribution is symmetrical; the range between the 97.5th percent lower and upper confidence limits was therefore assumed to encompass the 95th percent confidence limits on the $\mathrm{LCt}_{50}$. The best-fitting model among those with an acceptable fit was identified using Akaike's Information Criterion, unless visual inspection identified poor fit in the region of interest (the benchmark response rate) (U.S. EPA, 2012). Outputs for 20\% response rates were likewise determined. The goodness-of-fit was characterized by a $p$-value. In the event of $p<0.10$ (a poor fit, per U.S. EPA, 2012), U.S. EPA recommended that modelers should first 
consider the possibility of problems with the data, rather than problems with the model fitting process. For this analysis the datum with the highest standardized residual error was typically eliminated and the analysis repeated with the reduced data set. If necessary, a second datum with the highest remaining residual error was eliminated to see if the data could be reduced to a data set yielding an acceptable $p$-value; exceptions are described below under Section 3.4. The analysis was interpreted as identifying an outlier if the resulting $\mathrm{LCt}_{50}$ confidence limits of the reduced data set were narrower than for the full data set. Because the findings for 30-min constant concentration exposures in this study series were consistent with data collected $\sim 1$ year earlier (Sweeney et al., 2014), results from both phases were combined for analysis of Profile 6.

\subsection{Estimation of the toxic load exponent}

A revised estimate of the toxic load exponent (" $n$ " in $C^{n} \times t$ ) for HCN was derived in a manner similar to that used for the previous estimate (Sweeney et al., 2014). The toxic load equation, $C^{n} \times t=k$ (where $k$ is a constant for a specific response level), was applied to the median lethal concentration, so $\left(\mathrm{LC}_{50}\right)^{n} \times t=\mathrm{TL}_{50}$. Taking the logarithm of this equation and rearranging:

$\log (t)=\log \left(\mathrm{TL}_{50}\right)-n \times \log \left(\mathrm{LC}_{50}\right)$

The logarithms of the $\mathrm{LC}_{50}$ estimates and durations for 2.33-, 5-, $10-, 15-$ and 30-min constant concentration exposures (Phase 1 and Phase 2 Profiles 1, 6, and 11 in Sweeney et al., 2014 and current data) were used as inputs to a linear regression to derive a $\mathrm{TL}_{50}$ (the intercept) and $n$ (the slope, multiplied by -1 ). The resulting toxic load exponent was substantially different from that determined previously based only on 5, 15, and 30-min exposures; as discussed below, the 2.33-min data were excluded from the final determination of the revised toxic load exponent (see Section 3.5).

\subsection{Comparisons of lethal toxic loads based on concentration vs. time profiles}

As previously described in Sweeney et al. (2014), two general expressions for the TL received during exposure to an airborne chemical (used for risk assessment applications), as a function of time, are:

$\mathrm{TL}=\int_{0}^{t_{\mathrm{all}}}[C(t)]^{n} d t$ or $\mathrm{TL}=\sum_{j=1}^{p} C_{j}^{n} \times \tau_{j}$

where, $C(t)=$ the instantaneous agent concentration as a function of time (ppm or $\left.\mathrm{mg} / \mathrm{m}^{3}\right), t_{\mathrm{all}}=$ the total exposure duration (minutes), $n=$ the toxic load exponent (dimensionless), $C_{j}=$ the mean concentration over interval $j\left(\mathrm{ppm}\right.$ or $\left.\mathrm{mg} / \mathrm{m}^{3}\right), \tau_{j}=$ the duration of interval $j$ (minutes), $p=$ the number of integration intervals (dimensionless).

TLs were computed both for an assumed perfect pulsed exposure using piecewise (PW) concentrations ( $\mathrm{TL}_{\mathrm{PW}}=\mathrm{C}_{1}{ }^{n} \times t_{1}+C_{2}{ }^{n} \times t_{2}$ ) (same as $p=3$ integration intervals) and the duration-averaged (DA) concentration $\left(\mathrm{TL}_{\mathrm{DA}}=C_{\mathrm{avg}}{ }^{n} \quad\left(t_{1}+t_{\mathrm{gap}}+t_{2}\right)\right.$; where $C_{\text {avg }}=\left(\left[C_{1} \times t_{1}+C_{2} \times t_{2}\right] /\left[t_{1}+t_{\text {gap }}+t_{2}\right]\right)(p=1$ integration interval $)$. TL were calculated for $50 \%$ and $20 \%$ lethality and their $95 \%$ confidence limits. For $\mathrm{TL}_{50}$,

$\mathrm{TL}_{50, \mathrm{DA}}=\left(\frac{\mathrm{LCt}_{50}}{t}\right)^{n} \times t$

and

$\mathrm{TL}_{50, \mathrm{PW}}=\mathrm{TL}_{50, \mathrm{DA}} \times \frac{\left(\mathrm{DR}+\frac{1}{\mathrm{CR}^{n}}\right)}{\left(\mathrm{DR}+\frac{1}{\mathrm{CR}}\right)^{n}} \times\left(\frac{1+\mathrm{DR}}{1-f}\right)^{(n-1)}$ where $f$ =gap duration (fraction of total duration; 0 or 0.3 ), $\mathrm{CR}=$ concentration ratio for pulses $\left(C_{1} / C_{2} ; 1 / 5\right.$ for all non-constant profiles, 1 for Profiles 1, 6, and 11), and DR = duration ratio for pulses $\left(t_{1} / t_{2} ; 1\right.$ or 2$)$. The equation for $\mathrm{TL}_{50, \mathrm{DA}}$ is from the definition; derivation of the algebraic relationship between $\mathrm{TL}_{50, \mathrm{DA}}$ and $\mathrm{TL}_{50, \mathrm{PW}}$ is provided as Appendix $\mathrm{B}$. $\mathrm{TL}_{\mathrm{PW}}$ is always greater than or equal to $T L_{D A}$ for the same concentration-time profile. The use of square-wave profiles (Fig. 1) establishes an exact mathematical relationship between the definitions of $\mathrm{TL}_{\mathrm{DA}}$ and $T \mathrm{~L}_{\mathrm{PW}}$, which does not exist in real-life exposure scenarios.

Statistical analyses of $\mathrm{TL}_{50}$ estimates were conducted using SigmaPlot (version 12.5); a $p$ value of $<0.05$ was used to establish statistically-significant differences. Groups to be compared were tested for normality using the Shapiro-Wilk test. Normally distributed data were tested for equality of variance; if variances were found to be equal, the group comparison was made using the 2tailed $t$-test. If the groups failed the Shapiro-Wilk test (i.e., data were determined not to be normally distributed) or found to have unequal variance, they were compared using the Mann-Whitney rank sum test for the comparison of medians. Comparisons were made between the following groups based on the design criteria: baseline vs. pulsed; short duration vs. long duration; continuous vs. discontinuous; small vs. large pulse height difference, pulse duration ratio (equal or unequal), and pulse height order (high then low vs. low then high).

\section{Results and discussion}

\subsection{Experimental and operating conditions}

The environmental and operating conditions for each exposure are reported in Supplementary Data Table S-1. Overall, the environmental conditions were very consistent among the 60 exposures, and within the specified ranges, with the exception of humidity. Humidity slightly exceeded $70 \%$ (70.4\% and $70.5 \%$ ) for two exposures. The reported achieved concentrations represent the averages of the last 2 min of each pulse and were within $1 \%$ of the target concentrations (Table A-1).

\subsection{Test animals}

The rats used in these experiments ranged in age from 5356 days and weighed between 211.8 and $320.0 \mathrm{~g}$ at exposure. Individual animal data (age, weight, exposure, exposure outcome) and age and weight summaries by profile are provided in Supplementary Data (Tables S-2 and S-3). Rat body weights were well balanced both across and within the 11 profiles. Among the 60 total trials (10 rats per trial), the lowest average body weight was $242.6 \mathrm{~g}$ (a trial of Profile 10), and the highest average weight was $279.0 \mathrm{~g}$ (a trial of Profile 7), roughly a $15 \%$ difference, so the 60 trials span a limited range. When aggregated across trials, the profile with (on average) the heaviest rats (Profile 2), was conducted with rats averaging $269.7 \mathrm{~g}$ (standard deviation $12.8 \mathrm{~g}$ ), while the profile with lightest rats used rats averaging $257.8 \mathrm{~g}$ (standard deviation $17.7 \mathrm{~g}$ ), so across the 11 profiles, the minimum and maximum of the average body weights differ by only $5 \%$. In the profile with the largest variability among trials (Profile 7), average weights had a mean of $265.5 \mathrm{~g}$ and standard deviation of $14 \mathrm{~g}$, for a coefficient of variation of $5 \%$ (Table S-3).

\subsection{Exposure outcomes summary}

Out of 600 exposed rats, approximately 56\% died within $24 \mathrm{~h}$ post-exposure and their deaths were attributed to HCN exposure (Table 1). All but two of those deaths occurred either during 
Table 1

Rat deaths attributed to hydrogen cyanide inhalation.

\begin{tabular}{|c|c|c|c|c|c|}
\hline \multirow[t]{2}{*}{ Profile } & \multirow{2}{*}{$\begin{array}{l}\text { Number of } \\
\text { animals } \\
\text { exposed }\end{array}$} & \multirow{2}{*}{$\begin{array}{l}\text { Number surviving } \\
24 \mathrm{~h} \\
\text { postexposure } \\
\text { period }\end{array}$} & \multicolumn{3}{|c|}{ Timing of deaths } \\
\hline & & & $\begin{array}{l}\text { During } \\
\text { exposure }\end{array}$ & $\begin{array}{l}0-1 \mathrm{~h} \\
\text { post- } \\
\text { exposure }\end{array}$ & $\begin{array}{l}1-24 \mathrm{~h} \\
\text { post- } \\
\text { exposure }\end{array}$ \\
\hline 1 & 50 & 22 & 28 & 0 & 0 \\
\hline 2 & 40 & 17 & 23 & 0 & 0 \\
\hline 3 & 40 & 15 & 25 & 0 & 0 \\
\hline 4 & 80 & 26 & 54 & 0 & 0 \\
\hline 5 & 40 & 16 & 24 & 0 & 0 \\
\hline 6 & 20 & 11 & 9 & 0 & 0 \\
\hline 7 & 60 & 32 & 28 & 0 & 0 \\
\hline 8 & 40 & 21 & 19 & 0 & 0 \\
\hline $9^{a}$ & 70 & 36 & 34 & 0 & 0 \\
\hline 10 & 90 & 36 & 53 & 1 & 0 \\
\hline 11 & 70 & 34 & 35 & 1 & 0 \\
\hline
\end{tabular}

a Total deaths indicates deaths within $24 \mathrm{~h}$ of exposure. One rat from Profile 9 died after the $24 \mathrm{~h}$ post-exposure period (died at $\sim 72.5 \mathrm{~h}$ post-exposure, cause undetermined) and is not included in that total.

Table 2

Initial clinical signs observed in rats surviving hydrogen cyanide exposure.

\begin{tabular}{|c|c|c|c|c|c|c|c|c|c|c|c|}
\hline \multirow[t]{2}{*}{ Clinical sign ${ }^{a}$} & \multicolumn{11}{|c|}{ Profile } \\
\hline & 1 & 2 & 3 & 4 & 5 & 6 & 7 & 8 & 9 & 10 & 11 \\
\hline Lethargy & 1 & 5 & 0 & 3 & 0 & 1 & 7 & 8 & 2 & 7 & 0 \\
\hline Labored breathing & 20 & 16 & 11 & 20 & 11 & 8 & 27 & 18 & 30 & 28 & 16 \\
\hline Gasping & 0 & 0 & 2 & 4 & 4 & 1 & 0 & 0 & 1 & 2 & 4 \\
\hline Tremors/twitching & 17 & 14 & 15 & 22 & 13 & 7 & 24 & 11 & 33 & 19 & 16 \\
\hline $\begin{array}{l}\text { Impaired } \\
\text { Movement/ } \\
\text { uncoordinated }\end{array}$ & 19 & 15 & 13 & 20 & 9 & 8 & 24 & 16 & 25 & 20 & 12 \\
\hline $\begin{array}{l}\text { Inability to remain } \\
\text { upright }\end{array}$ & 0 & 1 & 1 & 3 & 5 & 0 & 0 & 0 & 3 & 2 & 8 \\
\hline $\begin{array}{l}\text { Bloody mouth, } \\
\text { nose, and/or } \\
\text { eyes }\end{array}$ & 0 & 1 & 1 & 2 & 3 & 0 & 6 & 1 & 3 & 8 & 5 \\
\hline Unresponsive & 0 & 0 & 1 & 3 & 5 & 0 & 0 & 0 & 2 & 1 & 7 \\
\hline $\begin{array}{c}\text { Total survivors } \\
\text { observed }\end{array}$ & 22 & 17 & 15 & 26 & 16 & 11 & 32 & 21 & 36 & 36 & 34 \\
\hline
\end{tabular}

a Reflects only the initial postexposure observations; more than one sign may have been observed per rat. exposure or during the post-exposure period $(5 \mathrm{~min}$ ) between the cessation of HCN exposure and removal of the rats from the exposure tower (removal of the animals by study personnel was delayed to allow for the clearance of HCN from the exposure tower prior to equipment and animal handling). Both of those two deaths occurred during the $1 \mathrm{~h}$ period after exposure designated for close observation of the animals. An additional post-exposure death was observed $\sim 3$ days after exposure; the cause was undetermined but for dose-response purposes was not attributed to $\mathrm{HCN}$ as the rat appeared normal at the $1 \mathrm{~h}$ and 24-h post-exposure observation points and subsequent evaluations. Many of the rats that survived the exposure initially displayed clinical signs such as labored breathing, impaired/uncoordinated movement, and tremors/ twitching (Table 2). With the exception of the two deaths noted above, most appeared fully recovered within $1 \mathrm{~h}$ and all survivors appeared fully recovered within $24 \mathrm{~h}$.

\subsection{Dose-response analysis}

The benchmark dose modeling results are summarized Table 3 . Our preference was to identify single, best LCt values and confidence limits when defensible (high quality model fit derived from consistent, logical data) or a range of likely values if a single, best LCt value could not be identified with confidence. For 6 of the 11 profiles, dose-response analyses using all of the trials yielded good to excellent fits ( $p=0.40$ to 0.89 for Profiles $1,2,3,5,6$, and 8 ). Two additional profiles (Profiles 10 and 11) each had one trial that was readily identified as an outlier, and the exclusion of the outlier caused a substantial improvement in the $p$-value associated with the best fit models (from $p<0.1$ to $p=0.64$ and 0.78 for profiles 10 and 11, respectively). Three profiles (Profiles 4, 7, and 9) were more difficult to evaluate and warrant further explanation.

The outcomes from Profile 4 were unusually inconsistent (Appendix A, Table A-1). When all of the individual trials were included, the best fit $p$-value was 0.0029 . Two trials of this profile with cumulative doses $(C \times t)$ that differed by $\sim 0.2 \%$ produced very different outcomes: 3 and 10 deaths out of 10 exposed animals per trial. When these two trials were combined (13 deaths out of 20 exposed), one model produced an acceptable $p$ value $(p=0.139)$, but the results were not usable because lower confidence limits

Table 3

Calculated lethality of inhaled HCN in male Sprague-Dawley rats (Phase 2).

\begin{tabular}{|c|c|c|c|c|c|c|c|}
\hline $\begin{array}{l}\text { Exposure } \\
\text { duration }\end{array}$ & Profile & $\begin{array}{l}\mathrm{LCt}_{50} \text { (95\% confidence interval) } \\
\text { (ppm min) }\end{array}$ & $\frac{\mathrm{LCt} 50}{\mathrm{LCt} 50 \mathrm{LCL}}$ & $\begin{array}{l}\mathrm{LCt}_{20} \text { (95\% confidence interval) } \\
(\mathrm{ppm} \text { min) }\end{array}$ & $\frac{\mathrm{LCt} 20}{\mathrm{LCt} 20 \mathrm{LCL}}$ & Model & $\begin{array}{l}\text { Model Fit } p \text { - } \\
\text { value }\end{array}$ \\
\hline \multirow[t]{6}{*}{$10 \mathrm{~min}$} & 1 & $6049(5414-6684)$ & 1.12 & 4919 (3670-6168) & 1.34 & Gamma & 0.88 \\
\hline & 2 & $6234(5462-7006)$ & 1.14 & $5070(3521-6619)$ & 1.44 & Gamma & 0.89 \\
\hline & 3 & $6016(5047-6985)$ & 1.19 & $4893(2995-6791)$ & 1.63 & Gamma & 0.41 \\
\hline & $4^{\mathrm{a}, \mathrm{b}}$ & 6329 (5099-7559) & 1.24 & $4639(2515-6763)$ & 1.84 & Weibull & 0.60 \\
\hline & $4^{\mathrm{a}, \mathrm{c}}$ & $5733(4849-6625)$ & 1.18 & 3185 (2204-4166) & 1.49 & Probit & 0.25 \\
\hline & 5 & $5972(5283-6661)$ & 1.13 & $4856(3591-6121)$ & 1.35 & Gamma & 0.75 \\
\hline \multirow[t]{7}{*}{$30 \mathrm{~min}$} & $6^{\mathrm{d}}$ & $7851(7287-8415)$ & 1.08 & 6384 (5769-6999) & 1.11 & Gamma & 0.89 \\
\hline & $7^{\mathrm{b}}$ & 8205 (7090-9320) & 1.16 & $6373(3463-9283)$ & 1.84 & Weibull & 0.46 \\
\hline & $7^{\mathrm{c}}$ & $6703(4570-8836)$ & 1.47 & $3382(1471-5293)$ & 2.30 & Weibull & 0.56 \\
\hline & $7^{e}$ & $8132(6583-9681)$ & 1.24 & $4366(3281-5452)$ & 1.33 & Logistic & 0.22 \\
\hline & 8 & $7636(6833-8439)$ & 1.12 & $6210(4998-7422)$ & 1.24 & Gamma & 0.40 \\
\hline & $9^{c}$ & 7799 (7054-8544) & 1.10 & $6123(3588-8658)$ & 1.71 & $\begin{array}{l}\text { Dichotomous- } \\
\text { Hill }\end{array}$ & 0.16 \\
\hline & $10^{c}$ & $6172(5667-6677)$ & 1.09 & $5019(4273-5765)$ & 1.17 & Gamma & 0.64 \\
\hline $2.33 \mathrm{~min}$ & $11^{\mathrm{c}}$ & $4460(4136-4784)$ & 1.08 & $3911(3438-4384)$ & 1.14 & Log-Probit & 0.78 \\
\hline
\end{tabular}

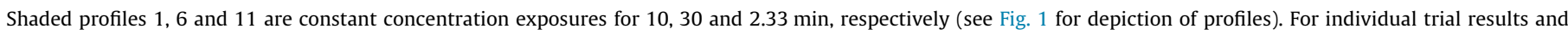
identification of trials dropped for dose-response analysis, see Appendix A, Table A-1.

a Two trials with roughly the same concentrations but very different outcomes (3/10 and 10/10) were combined.

b Two trials dropped.

c One trial dropped.

d Previous data from the same laboratory (Sweeney et al., 2014) were combined with data from two additional trials.

e All data included in estimation of LCt values, but these values were not used in toxic load model assessment. 
on the LCt values could not be computed. In reviewing the estimated times of death for these two trials and the excluded trial, no unusual patterns were noted in the timing of the deaths, relative to other trials for this profile (data not shown). When the trial with the highest standardized residual error was removed, fit improved to $p=0.25$; removal of a second trial improved fit to $p=0.60$, but slightly increased the $\mathrm{LCt}_{50} / \mathrm{LCt}_{50 \mathrm{LCL}}$ ratio.

It was difficult to discern which point or points should be excluded from Profile 7 to achieve an improved fit (as compared to including all of the data, which yielded acceptable $(p>0.1)$ but relatively poor quality fits ( $p=0.17$ to 0.22 in usable models). If a single datum was eliminated, fit improved, but the $\mathrm{LCt}_{50} / \mathrm{LCt}_{50 \mathrm{LCL}}$ ratio was unusually high and the $\mathrm{LCt}_{20}$ was not consistent with that observed for other 30-min exposures. If two points were to be eliminated, it appeared to make the most sense not to include the first point eliminated, but instead to remove two different points; the overall quality of the fit ( $p$ value) decreased (from 0.56 to 0.46 ), but the confidence in the $\mathrm{LCt}_{50}$ estimate improved. One of the excluded trials (69.9 ppm for $20 \mathrm{~min}, 355.7 \mathrm{ppm}$ for $10 \mathrm{~min}$ ) included two deaths identified early in the second pulse (21:20 and 22:36), the earliest identified deaths for this profile, so it is possible that this trial happened to have two unusually susceptible rats.

Similar to Profile 7, inclusion of all of the Profile 9 data did not produce acceptable model fits $(p<0.1)$, but it was not clear which data should be excluded. Exclusion of one data point (two different points were tested) produced improved fits to the data $(p=0.13$ and 0.16$)$, but the possibility of further improvement was explored. Various combinations of two data points were deleted; some analyses yielded no acceptable model fits; the results of alternative analyses with two data points dropped did not substantially improve the fit or alter the BMD (data not shown).

The alternative LCt estimates were carried forward into the TL computations (see below) so that the impact (if any) of the choice of which trials to exclude could be assessed.

\subsection{Determination of the toxic load exponent}

$\mathrm{LC}_{50}$ values for the 2.33-, 5-, 10-, 15, and 30-min constant concentration exposures conducted in this laboratory (data of Sweeney et al., 2014 and current data) were initially used to derive a new estimate of the toxic load exponent (Fig. 2). When all 5 exposure durations were used, the toxic load exponent decreased to

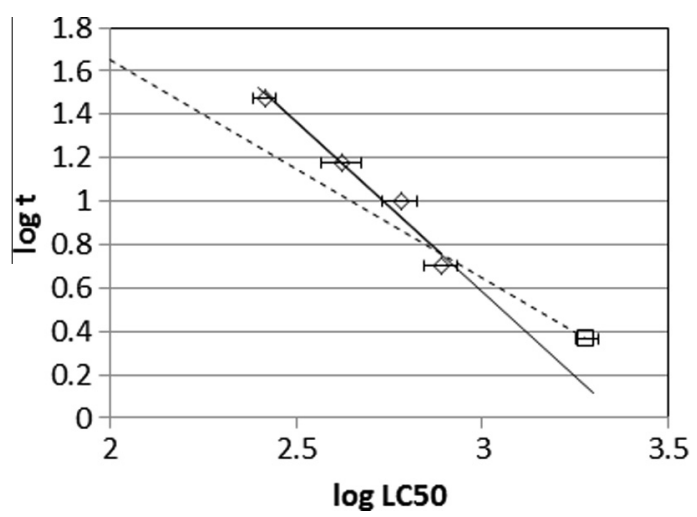

Fig. 2. Acute lethality ( $\mathrm{LC}_{50}$ in $\mathrm{ppm}, t$ in minutes) of inhaled hydrogen cyanide in male Sprague-Dawley rats (current data and Sweeney et al., 2014, mean $\pm 95 \%$ confidence limits). Diamonds indicate data used to derive the regression line (solid line; slope $=-1.57$ ); the square indicates $2.33-\mathrm{min} \mathrm{LC}_{50}$, which was excluded from this analysis. The dashed line indicates predictions of $\mathrm{LC}_{50}$ values associated extrapolated from the 2.33-min $\mathrm{LC}_{50}$ to other exposure durations if $\mathrm{HCN}$ lethality conformed to Haber's Law (slope $=-1$ ).
1.31 , and the $95 \%$ confidence limits for the 5 -min $\mathrm{TL}_{50}$ were below the range identified for the other 4 durations (data not shown). If only the 2.33- and 5-min data are considered (the two points furthest to the right in Fig. 2), HCN lethality approximately follows Haber's Rule (that is, the toxic load exponent is approximately 1 ), however, none of the $\mathrm{LC}_{50}$ value estimates for longer exposures are consistent with Haber's Rule. When the 2.33-min data were excluded, the $\log t$ vs. $\log \mathrm{LC}_{50}$ linear regression had an $r^{2}$ of 0.97 and the estimated toxic load exponent was 1.57 ( $-1 \times$ slope), similar to the value of 1.66 determined in this laboratory from the 5,15 , and 30-min data alone (Sweeney et al., 2014). The median lethal toxic load estimate was $194 \times 10^{3} \mathrm{ppm}^{1.57} \mathrm{~min}$. Using the toxic load exponent of 1.57 , the $\mathrm{TL}_{50}$ estimates for 5-, 10-, 15-, and 30min constant concentration exposures (Phase 1 Profile 1, Phase 2 Profile 1, Phase 1 Profile 11, and Phase 2, Profile 6, respectively) had overlapping $95 \%$ confidence ranges (Fig. 3). A toxic load exponent of 1.57 rather than 1.31 was used in all subsequent $\mathrm{TL}_{50}$ calculations due to the likelihood physiological adaptations were occurring during the shortest (2.33-min) exposures (Pauluhn, 2006). A similar analysis was completed for the $\mathrm{LC}_{20}$ values. Again, the 2.33-min exposure appeared to be an outlier; a toxic load exponent of 1.53 was determined from the 5-, 10-, 15-, and 30 -min $\mathrm{LC}_{20}$ values.

\subsection{Discrimination between alternate methods for computation of the toxic load}

The $\mathrm{TL}_{50}$ values for the present data and revised $\mathrm{TL}_{50}$ values for the exposures from Phase 1 (Sweeney et al., 2014) were computed using the piecewise and duration-averaged methods (see above, Section 2.10). The $\mathrm{TL}_{50}$ and 95\% confidence limits for Phase 2 Profile 11 (2.33-min of continuous exposure) were observed to fall entirely outside the $95 \%$ confidence limits derived for the other baseline profiles (Fig. 3).

Under the duration-averaged approach, Phase 2 Profile 10 was the only time-varying profile that appeared not to conform to the toxic load model (Fig. 3). When the piecewise approach was used, the profiles with a brief pulse of exposure (less than $5 \mathrm{~min}$; Ph1 to $\mathrm{Ph} 2 \mathrm{P} 5$ ) appeared not to conform to the toxic load model (minimal overlap between the baseline TL range and the TL ranges of these profiles). The lack of conformation to the toxic load model held true for both the 2.33-min continuous exposure (Ph2P11) and the 5 or $10 \mathrm{~min}$ exposures with a gap (Phases 1 and 2, Profiles 4 and 5). In contrast, the piecewise TLs for non-constant profiles tended to be slightly elevated and duration average profiles slightly lower relative to the 5 - to 30 -min constant profile TLs, but both approaches were predominantly within the range established by the baseline TLs.

The 2.33-min HCN exposure clearly does not conform to the toxic load model established by the 5-30 min data (Fig. 3). It follows logically that pulsed exposures that incorporate isolated pulses of similarly brief duration (i.e., exposure Profiles 4 and 5 from both phases) would be likely to deviate from the toxic load model in a similar manner, while other exposures (isolated pulses or continuous exposure $\geqslant 5 \mathrm{~min}$ ) would be expect to be in agreement with the model. When the best estimates for the piecewise TLs were used (that is, the alternative values for Phase 2, Profiles 4, 7, and 9 are omitted), all 5 "short" TLs were outside the bounds established by the constant exposures, with 13 of 16 longer exposures within the bounds. When similar comparisons were made for the duration averaged exposures, somewhat better agreement was found for the longer exposures (15/16 within the bounds), but duration averaging was less likely to discriminate that short pulses do not conform (3/5 outside the bounds, 2/4 non-constant exposures outside the bounds). That is to say, the piecewise approach does a substantially better job at identifying the "true negatives" 


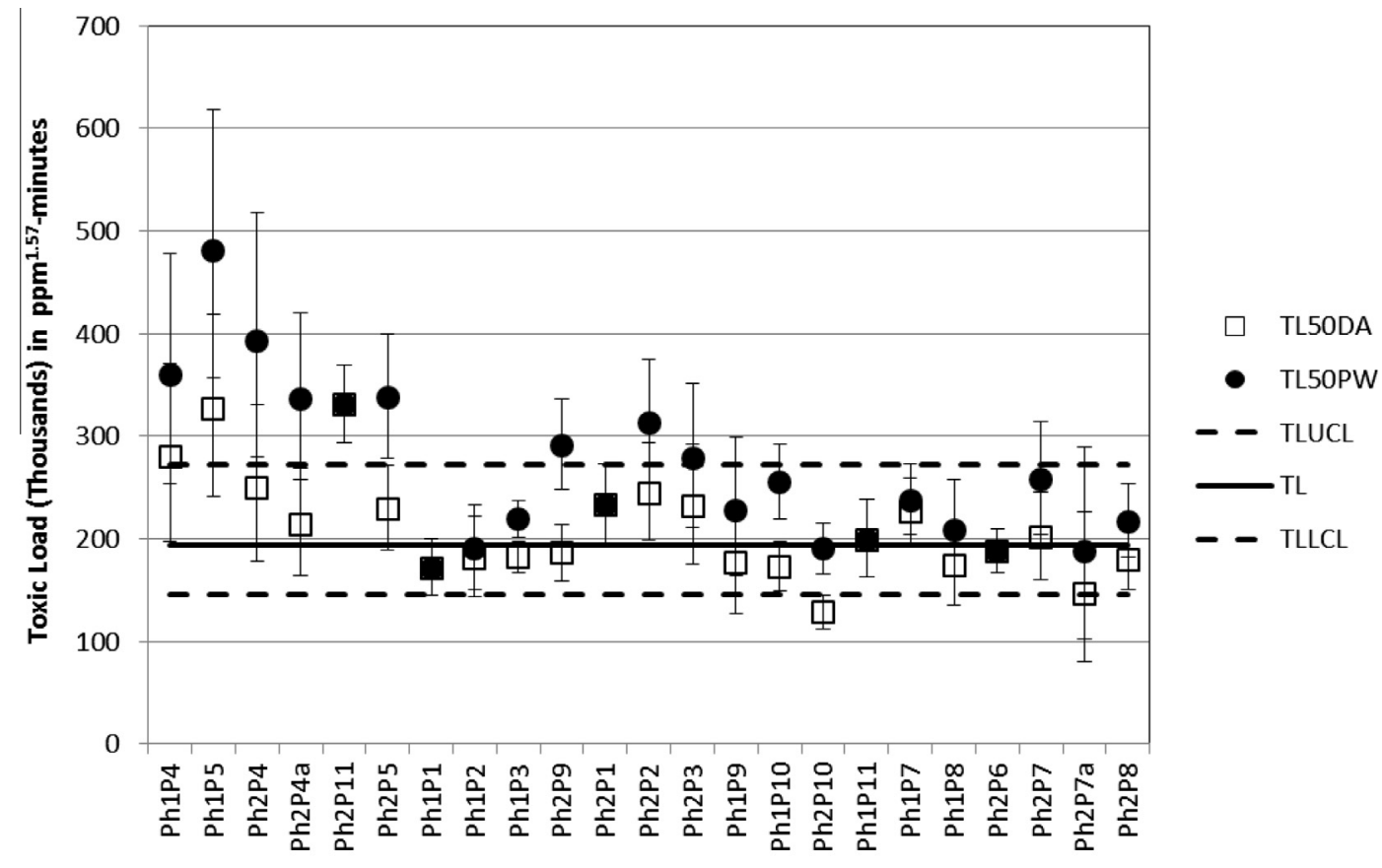

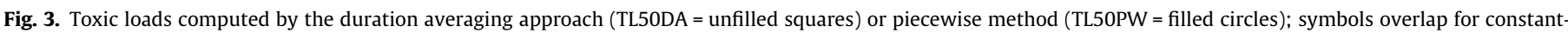

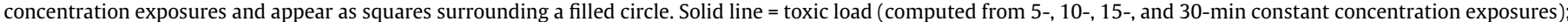

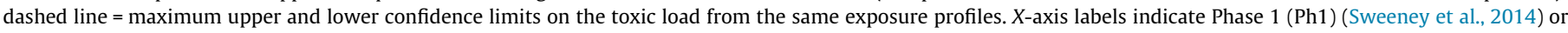

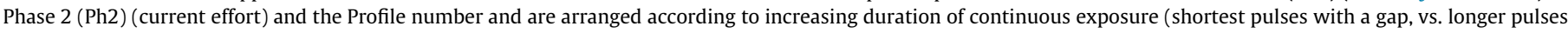
with no gap, or 30-min continuous exposure).

than the duration approach, whereas the duration averaging approach does a slightly better job at identifying the "true positives". Therefore it was concluded that, on the whole, the piecewise TL computations capture the difference between exposure profiles slightly better than the duration-averaged approach. However, since the data were not conclusive, both the piecewise and duration averaged approaches were used for comparisons among profiles. The use of alterative TL values for Phase 2 Profiles 4 and 7 (Ph2P4a and Ph2P7a) would have no impact on these conclusions about the two approaches.

\subsection{Comparisons of median lethal toxic loads based on concentration vs. time profiles}

The comparisons of $\mathrm{TL}_{50}$ s for $C$ vs. $t$ profiles grouped by common characteristics are summarized in Table 4; eligible profiles were limited to those with no pulse less than $5 \mathrm{~min}$ due to

Table 4

Comparison of acute $\mathrm{TL}_{50} \mathrm{~s}$ for acute inhalation of $\mathrm{HCN}$ by male Sprague-Dawley rats.

\begin{tabular}{|c|c|}
\hline Exposure profiles compared & Finding \\
\hline Constant vs. pulsed & $\begin{array}{l}\text { Limited support for a difference in } \mathrm{TL}_{50} \\
\text { values }^{\mathrm{a}} \text { (piecewise) }\end{array}$ \\
\hline Pulse height order & Not statistically significant \\
\hline Pulse duration ratio & $\begin{array}{l}\text { Limited support for a difference in } \mathrm{TL}_{50} \\
\text { values }^{\mathrm{a}} \text { (piecewise) }\end{array}$ \\
\hline No gap vs. gap & $\begin{array}{l}\text { Limited support for a difference in } \mathrm{TL}_{50} \\
\text { values }^{\mathrm{a}} \text { (duration averaged) }\end{array}$ \\
\hline $\begin{array}{l}\text { Shorter duration ( } 5-15 \mathrm{~min}) \text { vs. } \\
\text { longer duration ( } 30 \mathrm{~min})\end{array}$ & Not statistically significant \\
\hline Pulse height ratio & Not statistically significant \\
\hline
\end{tabular}

a Statistically significant at $p<0.05$ based on the best-supported interpretation of the dose-response data (Table 1 ); but not statistically significant using alternative interpretations of dose-response data. concerns about deviations from the toxic load model for short, isolated pulses. Phase 1 exposures (Sweeney et al., 2014, summarized in Appendix A, Table A-2) were included if they met the eligibility criteria; revised piecewise Phase 1 TLs were calculated using a toxic load exponent of 1.57. Comparisons were made based only on the central tendency estimates for TLs and thus do not account for the uncertainty in the lethality estimates for each profile.

\subsubsection{Constant vs. pulsed exposures}

Constant concentration exposures were compared to pulsed exposures (Sweeney et al., 2014 Profiles 1 and 11 and current Profiles 6 and 11 vs. Sweeney et al., 2014 Profiles 7-10 and current Profiles 3 and 7-10). The difference was found to be marginally statistically significant $(p=0.047)$ using piecewise computation, but not duration averaging. If the most uncertain results (current Profile 7) were omitted or the alternate results were used, the difference was no longer statistically significant ( $p=0.10$ or 0.13 , respectively).

\subsubsection{Pulse height order}

Exposures where the high concentration pulse preceded the low concentration pulse were compared to exposures conducted with the reverse ordering (Sweeney et al., 2014 Profiles 7-10 vs. current Profiles 3 and 7-10). No statistically significant difference was identified. Two profiles from the current study (Profiles 8 and 10) were mirror images of profiles from Sweeney et al. (2014) (also Profiles number 8 and 10). The current Profile 8, where the low concentration pulse preceded the high concentration pulse and there was no gap, had an $\mathrm{LCt}_{50}$ of $7636 \mathrm{ppm}$ min (95\% confidence interval of 6833-8439 ppm min) whereas when the pulse height order was reversed (Sweeney et al., 2014), the $\mathbf{L C t}_{50}$ was $7463 \mathrm{ppm}$ min (95\% confidence interval of $6375-8551 \mathrm{ppm}$ min). Thus no difference is apparent for this pair of profiles. For Profile 
10 , the current and prior studies identified $\mathrm{LCt}_{50}$ values (95\% confidence interval) of 6172 (5667-6677) ppm min vs. 7445 (67708119) ppm min While the lack of overlap in confidence intervals may suggest a difference in toxicity, it should be noted that the Profile 10 of Sweeney et al. (2014) had the most uncertain results. With two of seven trials dropped, the Phase 1 Profile 10 reduced data set still had a relatively poor fit $(p=0.21)$; inclusion of the excluded data sets would have led to lower $\mathrm{LCt}_{50}$ estimates (5723-6811 ppm min, depending on the model) but very poor fit $(p=0.0010-0.0014)$.

\subsubsection{Pulse duration ratio}

Exposures where the pulse durations were unequal were compared to the other exposures (current Profiles 7 and 9 vs. all other eligible profiles). The difference was found to be marginally statistically significant $(p=0.040$ ) using piecewise computation, but not duration averaging. The two profiles with unequal pulse durations had the most uncertain dose-response analysis results in the current investigation; if the alternate results were used, the difference was no longer statistically significant $(p=0.36)$.

\subsubsection{Gap vs. no gap}

Exposures that included a gap of $30 \%$ of the total exposure duration were compared to those that did not (Sweeney et al., 2014 Profiles1, 7, 8, and 11 and current Profiles 1, 3, 6, 7, 8 vs. Sweeney et al., 2014 Profiles 9 and 10 and current profiles 9 and 10). No statistically significant difference was found using a piecewise approach. A marginally statistically significant difference was found using the duration averaged approach $(p=0.0416)$ that was no longer significant if the alternative TL for the current Profile 9 was used.

\subsubsection{Shorter vs. longer duration}

Toxic loads for shorter (5, 10 or $15 \mathrm{~min}$ ) and longer (30 min) exposures were compared (Sweeney et al., 2014 Profiles 1 and 11 and current profiles 1 and 3 vs. Sweeney et al., 2014 Profiles 710 and current Profiles 6-10). No statistically significant difference was identified.

\subsubsection{Pulse height ratio}

Exposures with a low pulse-height ratio (i.e., constant exposures or a 2:1 ratio) did not have $\mathrm{TL}_{50}$ values that differed significantly from exposures with a larger pulse height ratio (5:1). This comparison was based on Sweeney et al. (2014) Profiles 1, 7, 9, and 11 and the current profiles 1 and 6 vs. Sweeney et al. (2014) Profiles 8 and 10 and the current Profiles 3 and 7-10.

\subsection{7. $T L_{20}$ results}

A parallel analysis was conducted for the $\mathrm{TL}_{20}$ values. No statistically significant differences were found between constant and nonconstant exposures (data not shown). It should be noted, however, that the uncertainties associated with the $\mathrm{TL}_{20}$ analysis are larger, however, because the experiments were designed to provide the more confidence in median lethal concentrations than the lower range of the dose-response curve.

\section{Conclusions}

Prior to the conduct of this study, the apparent protective effect of a gap during the 5-min exposure (Sweeney et al., 2014) was hypothesized to be due to a compensatory behavior (e.g., breath holding or something similar) that can only be sustained during a short exposure (i.e., less than $5 \mathrm{~min}$ ). By testing a shorter constant-concentration exposure (current Profile 11, 2.33 min) and two different pulse widths, we sought to more finely discern the maximal duration for the compensatory behavior. The $\mathrm{LCt}_{50}$ for the 2.33-min exposure exceed that of the 5-min exposure, an observation that indicates behavior inconsistent with a toxic load exponent $>1$. Differences between the toxic load model and the computed TLs for Phase 2 Profiles 2, 4, and 5 further suggest that exposure profiles with pulses as long as $3.5 \mathrm{~min}$ may not conform to the toxic load model due to pulse duration alone, independent of other exposure profile characteristics. Taken together, these findings support that physiological compensation, likely via breath holding in the rodent subjects, is a confounding factor in very short exposure toxicity estimation. Therefore, the 15 and 30-min exposure profiles from Phase 1 (Sweeney et al., 2014, Profiles 1 and 6-11), and Phase 2 Profiles 1, 3, and 6-11 were deemed to be the best basis for evaluating the impact of other factors (e.g., gaps, pulse height ratio, pulse duration ratio) on computed TLs, and thus for evaluating the validity/limits of the TL model for non-constant exposure profiles more consistent with real world scenarios.

The 30-min piecewise TLs from non-constant exposures from both Phase 1 (Sweeney et al., 2014) and Phase 2 were fairly consistently (but not dramatically) higher than the baseline TL. It should be noted that the ratio of the piecewise TL to the durationaveraged TL varies among profiles and is fixed based on the profile characteristics (gap duration, pulse duration ratio, pulse concentration ratio) and nature of the chemical (toxic load exponent). Thus, profiles differ in their inherent capacity to distinguish between the two computational approaches; the profiles with greater power in this regard have larger separation between the computed $\mathrm{TL}_{\mathrm{PW}}$ and $\mathrm{TL}_{\mathrm{DA}}$ (Fig. 2). Based on the currently available data, the superiority of each model can be supported by some aspects of the findings. For example Phase 2 Profiles 9 and 10 both have relatively high $T L_{P W} / T_{P A}$ ratios (i.e. similar power to discriminate between models), but the Phase 2 Profile 9 duration averages results were more consistent with the toxic load model, while the Phase 2 Profile 10 results were more consistent with the piecewise approach. Ideally, future studies would be designed to maximize the power to discriminate among the models and reduce uncertainty.

The comparisons between sets of profiles grouped by various characteristics (e.g., presence of a gap, pulse concentration ratio, pulse height order) were restricted to profiles with no short, isolated pulses to reduce the potential for confounding due to breath holding or other adaptations. These short-term responses are of questionable significance to humans as rats have been noted to have increased responsiveness to respiratory irritants due to increased vagal activity and other rodent-specific defense mechanisms (Pauluhn, 2006). These comparisons provided only very limited support for conditions that might invalidate the toxic load model: pulsed concentrations in general, vs. constant concentrations, the presence of a gap in the exposure, and differences in the duration of the pulses. In the latter case, only two profiles have been tested where the pulse durations were unequal, so the data were very limited, and the conclusion preliminary. In particular, the importance of a gap was hard to evaluate because these scenarios appear to produce the most variable data (e.g., two of the three profiles that presented the greatest challenge for dose-response analysis contained gaps). A 30\% gap in a 30 min exposure produces a 9 min period with no exposure. To put this gap duration in the context of clearance, the cyanide half-life in blood of rats orally dosed with potassium cyanide has been reported as $14 \mathrm{~min}$ (Leuschner et al., 1991) or $38 \mathrm{~min}$ (Sousa et al., 2003). Thus, we conclude that overall, the data were supportive of the validity of the toxic load model for continuous exposures of rats for $5 \mathrm{~min}$ or more, but some uncertainty remains for exposures with a gap 
and of differing pulse duration. While these conclusions were developed using a rat model, we anticipate that they would likewise be applicable to humans or other species of interest for similarly fast acting compound. With regard to hydrogen cyanide in particular, the elimination half-life in exhaled air for humans was $15.6 \pm 3.9$ min (Stamyr et al., 2008), similar to the rat blood cyanide half-life reported by Leuschner et al. (1991), suggesting the impact of "gaps" of toxicokinetics might be similar. Stamyr et al. (2014) recently used physiologically based pharmacokinetic modeling of HCN lethality from human case reports with times to death ranging from $\sim 7$ to $60 \mathrm{~min}$ to derive a toxic load exponent of 2.4. This human value is slightly higher than the value of 1.6 for rats (derived herein) and the value of 2.1 for monkeys derived by the National Research Council (2002). The similarities of both half-life and toxic load exponent between rats and humans suggest the conclusions drawn from the current rat study would be applicable to hydrogen cyanide lethality in humans exposed to varying $C$ vs. $t$ patterns.

Rhomberg (2009) and Saltzman (1996) both explored the relationship between exposure concentration and body burden throughout the time course of an inhalation exposure. Saltzman (1996) considered fluctuating exposures (sine wave concentrations) and observed that if the air concentration averaging time was less than 1/4 the biological half-life, the short-term variation in the exposure has little impact on time course for the body burden, under conditions of first order kinetics. Rhomberg (2009) found that for exposure durations of less than or equal to one half-life, body burdens followed Haber's rule, after 4 or more half-lives, they were proportional to exposure concentration, and in the intermediate range, the ten Berge equation (toxic load model) was a better approximation. Body burden alone is not necessarily a predictor of toxic response, as it does not account for the balance between damage and repair (Rhomberg, 2009). For rats given oral doses of cyanogens (at $0.75 \times \mathrm{LD}_{50}$ ), a direct relationship between blood and tissue cyanide levels and cytochrome oxidase inhibition was demonstrated, consistent with minimal lag time for onset and recovery once toxic levels of cyanide have been reached in tissues (Rao et al., 2013). Nonetheless, the rat hydrogen cyanide lethality data were consistent with a toxic load exponent closer to "1" (Haber's rule) at the shorter times we tested (2.33$5 \mathrm{~min}$ ) (Fig. 2), as indicated by Rhomberg (2009) and better described by the ten Berge equation for longer exposure durations ( $\sim 2$ times the half-life, or $30 \mathrm{~min}$ ).

\section{Funding statement}

This work was supported by the Defense Threat Reduction Agency. Dr. Sweeney, Mr. Sharits, Mr. Gargas and Mr. Gut's efforts were conducted under Work Unit Number H1107.

\section{Disclaimers}

The views expressed in this article are those of the authors and do not necessarily reflect the official policy or position of the Department of Defense, nor the U.S. Government.

The experiments reported herein were conducted in compliance with the Animal Welfare Act and in accordance with the principles set forth in the "Guide for the Care and Use of Laboratory Animals," Institute of Laboratory Animal Resources, National Research Council, National Academy Press, 1996.

The authors are either an employee or contract employees of the U.S. Government. This work was prepared as part of their official duties. Title 17 U.S.C. $§ 105$ provides that 'Copyright protection under this title is not available for any work of the United States Government.' Title 17 U.S.C. §101 defines a U.S. Government work as a work prepared by a military service member or employee of the U.S. Government as part of that person's official duties.

\section{Acknowledgments}

The authors would like to thank the following staff at Wright Patterson Air Force Base: Michelle Goodwin of CAMRIS for animal handling and observation and the Vivarium staff for animal care and husbandry. The authors would also like to thank Jerry Glasow of the Defense Threat Reduction Agency and John Cockayne of Leidos.

\section{Appendix A}

24-h outcomes for each HCN inhalation trial are provided in Table A-1. Dose-response plots are provided in Figs. A-1 and A-2.

Table A-1

24-h lethality data for $\mathrm{HCN}$ inhalation by male Sprague-Dawley rats. (See Fig. 1 for $C$ vs. $t$ profile depictions).

\begin{tabular}{|c|c|c|c|c|c|c|c|c|}
\hline $\begin{array}{l}\text { Concentration } \\
(\mathrm{ppm})\end{array}$ & $\begin{array}{l}C_{\mathrm{avg}} \times t \\
(\mathrm{ppm} \min )\end{array}$ & $\begin{array}{l}\text { Deaths (out of } \\
\text { 10) }\end{array}$ & $\begin{array}{l}\text { Concentration } \\
(\mathrm{ppm})\end{array}$ & $\begin{array}{l}C_{\mathrm{avg}} \times t \\
(\mathrm{ppm} \min )\end{array}$ & $\begin{array}{l}\text { Deaths (out of } \\
\text { 10) }\end{array}$ & $\begin{array}{l}\text { Concentration } \\
(\mathrm{ppm})\end{array}$ & $\begin{array}{l}C_{\text {avg }} \times t \\
(\mathrm{ppm} \min )\end{array}$ & $\begin{array}{l}\text { Deaths (out of } \\
\text { 10) }\end{array}$ \\
\hline \multicolumn{9}{|l|}{ 10-min profiles } \\
\hline $\begin{array}{l}\text { Profile } 1 \\
\quad \text { (10-min pulse) }\end{array}$ & & & \multicolumn{3}{|c|}{$\begin{array}{l}\text { Profile } 2 \\
\text { (6.67-min pulse, no gap, 3.33-min pulse) }\end{array}$} & \multirow{2}{*}{\multicolumn{2}{|c|}{$\begin{array}{l}\text { Profile } 3 \\
\text { (5-min pulse, no gap, 5-min pulse) }\end{array}$}} & \\
\hline $489.3 \pm 1.6$ & 4893.0 & 2 & & & & & & \\
\hline $590.0 \pm 4.3$ & 5900.0 & 4 & $\begin{array}{l}234.2 \pm 1.4 / \\
1175.3 \pm 3.8\end{array}$ & 5479.0 & 2 & $\begin{array}{l}183.4 \pm 1.2 / \\
899.9 \pm 3.0\end{array}$ & 5416.5 & 3 \\
\hline $642.5 \pm 2.4$ & 6425.0 & 5 & $\begin{array}{l}265.5 \pm 1.4 / \\
1299.7 \pm 5.4\end{array}$ & 6101.3 & 5 & $\begin{array}{l}205.1 \pm 1.3 / \\
1014.4 \pm 3.9\end{array}$ & 6097.5 & 6 \\
\hline $681.3 \pm 2.4$ & 6813.0 & 8 & $\begin{array}{l}297.7 \pm 1.5 / \\
1442.6 \pm 4.3\end{array}$ & 6793.3 & 7 & $\begin{array}{l}261.7 \pm 1.3 / \\
1157.6 \pm 4.5\end{array}$ & 7096.5 & 6 \\
\hline $778.0 \pm 2.9$ & 7780.0 & 9 & $\begin{array}{l}357.6 \pm 1.9 / \\
1780.0 \pm 6.7\end{array}$ & 8317.3 & 9 & $\begin{array}{l}270.8 \pm 1.5 / \\
1331.8 \pm 4.9\end{array}$ & 8013.0 & 10 \\
\hline $\begin{array}{l}\text { Profile } 4 \\
\quad \text { (4.67-min pulse, }\end{array}$ & -min gap, 2.3 & in pulse) & $\begin{array}{l}\text { Profile } 5 \\
\text { ( } 3.5 \text { min pulse, }\end{array}$ & gap, $3.5 \mathrm{mi}$ & lse) & & & \\
\hline $\begin{array}{l}277.8 \pm 1.9 / \\
\quad 1368.6 \pm 5.6\end{array}$ & 4489.8 & $6^{\mathrm{a}}$ & & & & & & \\
\hline $\begin{array}{l}322.7 \pm 1.8 / \\
1573.6 \pm 4.7\end{array}$ & 5177.7 & 3 & & & & & & \\
\hline $\begin{array}{l}376.6 \pm 1.8 / \\
1847.7 \pm 8.7\end{array}$ & 6068.8 & 5 & $\begin{array}{l}273.0 \pm 1.4 / \\
1280.4 \pm 3.7\end{array}$ & 5436.9 & 3 & & & \\
\hline
\end{tabular}


Table A-1 (continued)

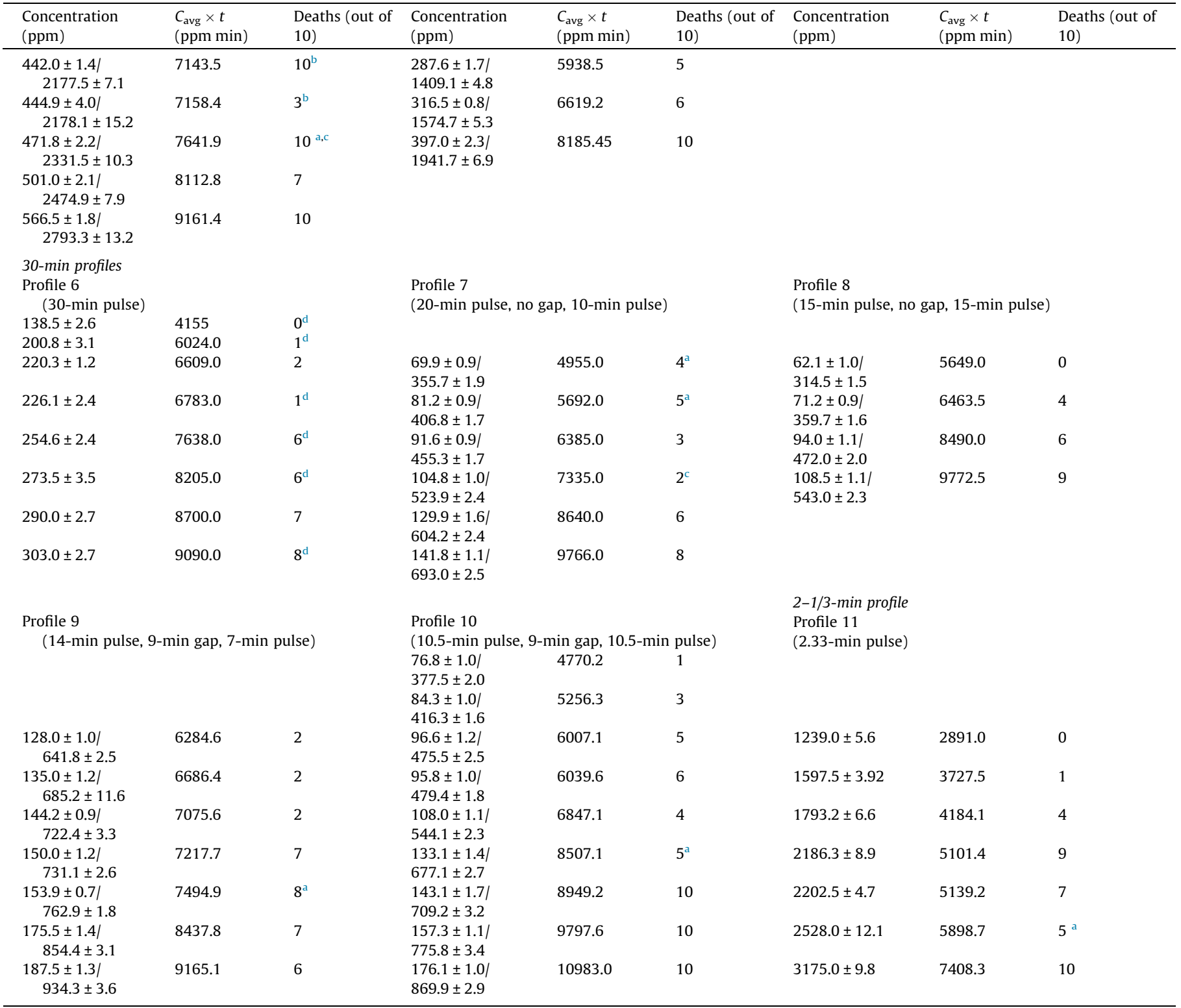

a Data point(s) dropped from preferred reduced data set for dose-response analysis.

b Data points combined for dose-response analysis $\left(C_{\mathrm{avg}} \times t=7151 \mathrm{ppm} \mathrm{min}\right.$; deaths $\left.=13 / 20\right)$.

c Data point dropped in alternative analysis (Table 3, italicized results).

d Phase 1 data (Sweeney et al., 2014).

Table A-2 provides a tabular summary of exposure scenarios and results from Sweeney et al. (2014).

\section{Appendix B}

Derivation of the relationship between two different methods for computing the toxic load.

By definition:

$t_{1}+t_{2}=(1-f) \times t_{\text {all }}$

and

$t_{1}=t_{2} \times \mathrm{DR}$

Therefore by substitution of Eq. (2) into Eq. (1): $t_{2} \times \mathrm{DR}+t_{2}=(1-f) \times t_{\mathrm{all}}$

Rearranging Eq. (1) to solve for $t_{2}$ :

$t_{2}=t_{\text {all }} \times(1-f) /(1+\mathrm{DR})$

Substituting Eq. (4) into Eq. (2):

$t_{1}=t_{\mathrm{all}} \times(1-f) \times \mathrm{DR} /(1+\mathrm{DR})$

By definition:

$\mathrm{TL}_{50, \mathrm{DA}}=\left(\mathrm{LCt}_{50} / t_{\mathrm{all}}\right)^{n} \times t_{\mathrm{all}}$

and

$\mathrm{TL}_{50, \mathrm{PW}}=\left(C_{1,50}\right)^{n} \times t_{1}+\left(C_{2,50}\right)^{n} \times t_{2}$ 


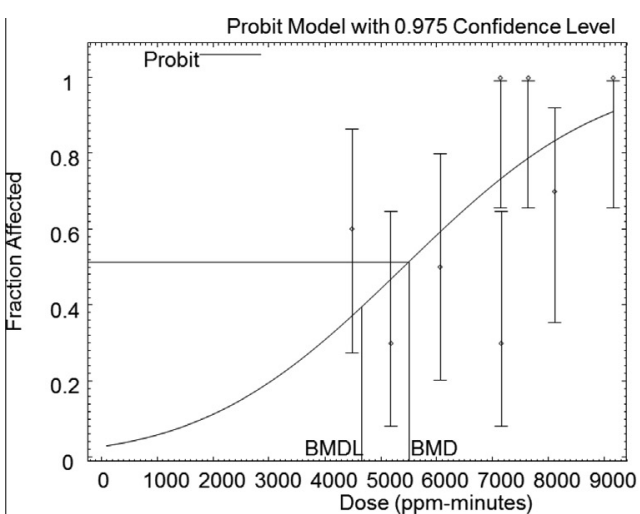

(a)

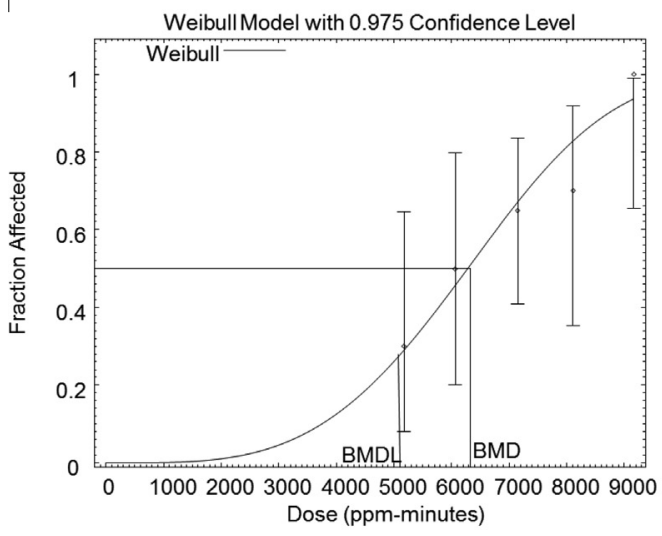

(c)

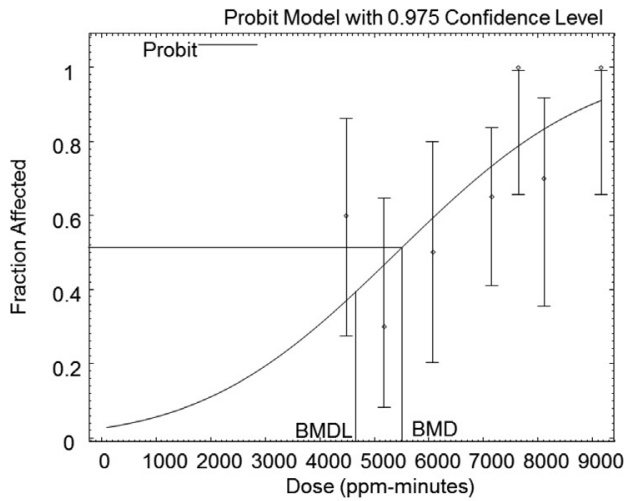

(b)

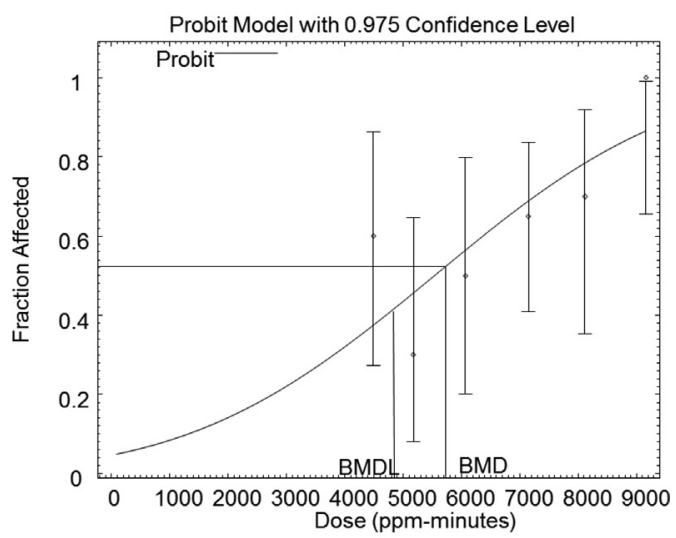

(d)

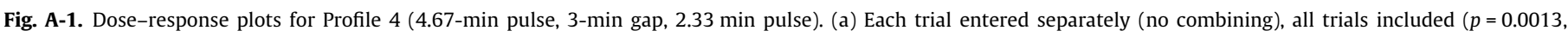

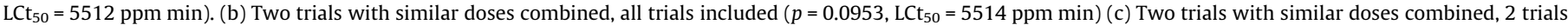
excluded $\left(p=0.604, \mathrm{LCt}_{50}=6329 \mathrm{ppm}\right.$ min) (selected). (d) Two trials with similar doses combined, 1 trial excluded $(p=0.25$, LCt $50=5733$ ppm min) (alternate).

and

$\left(C_{1,50}\right)=\mathrm{CR} \times\left(C_{2,50}\right)$

Substituting Eq. (8) and Eq. (2) into Eq. (7):

$\mathrm{TL}_{50, \mathrm{PW}}=\left(C_{1,50}\right)^{n} \times t_{2} \times \mathrm{DR}+\left(C_{1,50}\right)^{n} \times t_{2} / \mathrm{CR}^{n}$

Rearranging the terms in Eq. (9):

$\mathrm{TL}_{50, \mathrm{PW}}=\left(C_{1,50}\right)^{n} \times t_{2} \times\left(\mathrm{DR}+1 / \mathrm{CR}^{n}\right)$

By definition:

$\mathrm{LCt}_{50}=\left(C_{1,50}\right) \times t_{1}+\left(C_{2,50}\right) \times t_{2}$

Substituting Eq. (8) and Eq. (2) into Eq. (11):

$\mathrm{LCt}_{50}=\left(C_{1,50}\right) \times t_{2} \times \mathrm{DR}+\left(C_{1,50}\right) \times t_{2} / \mathrm{CR}$

Rearranging terms in Eq. (12):

$\mathrm{LCt}_{50}=\left(C_{1,50}\right) \times t_{2} \times(\mathrm{DR}+1 / \mathrm{CR})$

Rearranging Eq. (13) to solve for $C_{1,50}$ :

$\left(C_{1,50}\right)=\mathrm{LCt}_{50} /\left(t_{2} \times(\mathrm{DR}+1 / \mathrm{CR})\right)$

Substituting Eq. (14) into Eq. (10):

$\mathrm{TL}_{50, \mathrm{PW}}=\left[\mathrm{LCt}_{50} /\left(t_{2} \times(\mathrm{DR}+1 / \mathrm{CR})\right)\right]^{n} \times t_{2} \times\left(\mathrm{DR}+1 / \mathrm{CR}^{n}\right)$

Rearranging terms in Eq. (15):

$$
\mathrm{TL}_{50, \mathrm{PW}}=\left[\mathrm{LCt}_{50}^{n} / t_{2}^{n-1}\right] \times\left(\mathrm{DR}+1 / \mathrm{CR}^{n}\right) /(\mathrm{DR}+1 / \mathrm{CR})^{n}
$$

Substituting Eq. (5) into Eq. (16):

$$
\begin{aligned}
\mathrm{TL}_{50, \mathrm{PW}}= & \mathrm{LCt}_{50}^{n} \times\left[(1+\mathrm{DR}) /\left(t_{\text {all }} \times(1-f)\right)\right]^{n-1} \times(\mathrm{DR} \\
& \left.+1 / \mathrm{CR}^{n}\right) /(\mathrm{DR}+1 / \mathrm{CR})^{n}
\end{aligned}
$$

Rearranging Eq. (17):

$$
\begin{aligned}
\mathrm{TL}_{50, \mathrm{PW}}= & \left(\mathrm{LCt}_{50} / t_{\mathrm{all}}\right)^{n} \times t_{\text {all }} \times[(1+\mathrm{DR}) /(1-f)]^{n-1} \times(\mathrm{DR} \\
& \left.+1 / \mathrm{CR}^{n}\right) /(\mathrm{DR}+1 / \mathrm{CR})^{n}
\end{aligned}
$$

Substituting Eq. (6) into Eq. (18):

$$
\begin{aligned}
\mathrm{TL}_{50, \mathrm{PW}}= & \mathrm{TL}_{50, \mathrm{DA}} \times\left(\mathrm{DR}+1 / \mathrm{CR}^{n}\right) /(\mathrm{DR}+1 / \mathrm{CR})^{n} \\
& \times[(1+\mathrm{DR}) /(1-f)]^{n-1}
\end{aligned}
$$

\section{Appendix C. Supplementary data}

Supplementary data associated with this article can be found, in the online version, at http://dx.doi.org/10.1016/j.yrtph.2015.02. 015. 


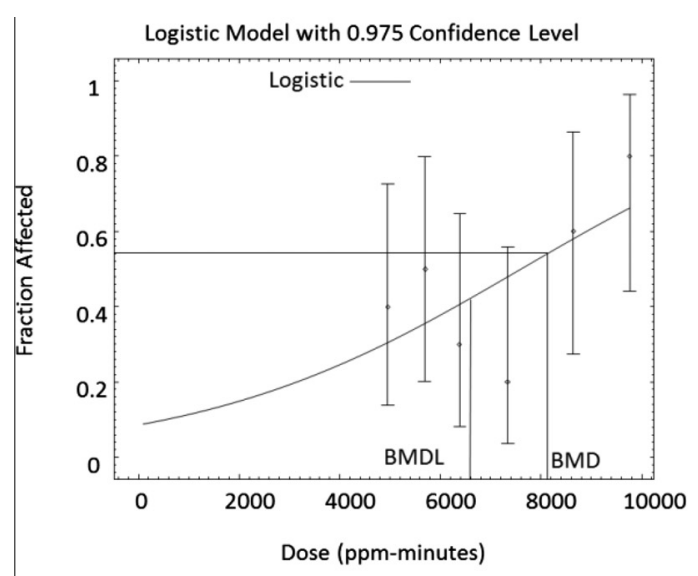

(a)

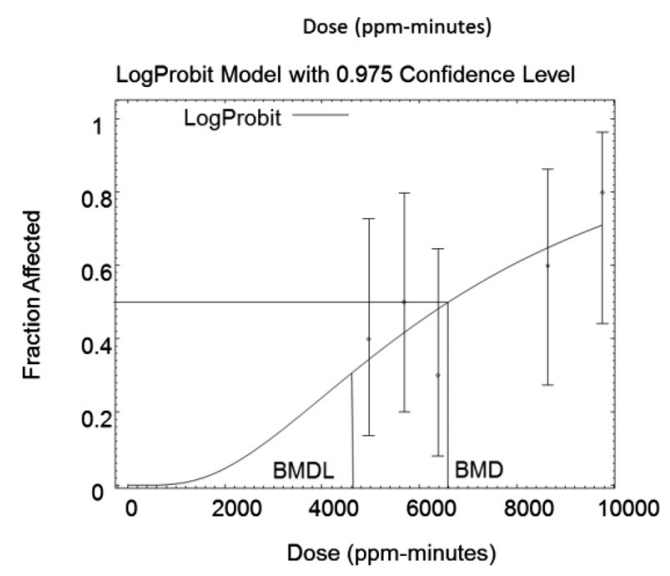

(b)

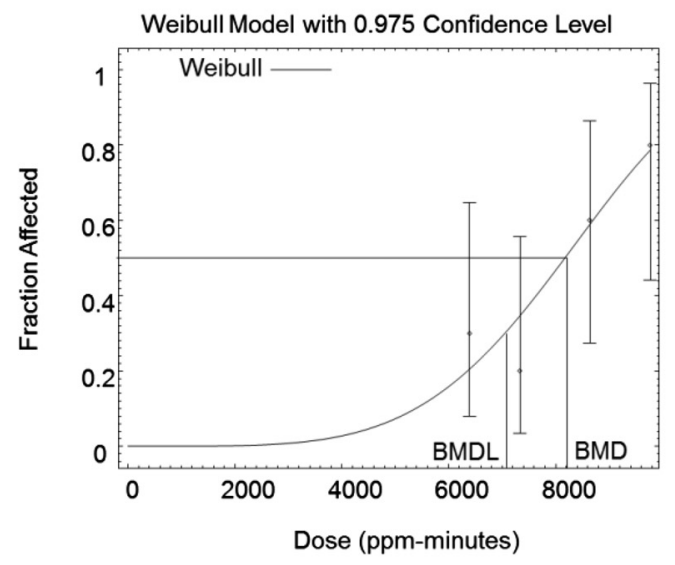

(c)

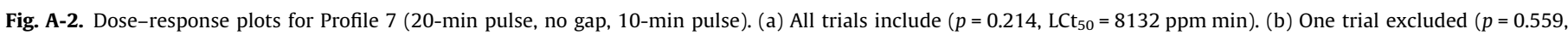
$\mathrm{LCt}_{50}=6703 \mathrm{ppm}$ min) (alternate). (c) Two trials excluded ( $p=0.463, \mathrm{LCt}_{50}=8205 \mathrm{ppm}$ min) (selected).

Table A-2

Test profiles and median acute lethality findings for HCN (Sweeney et al., 2014).

\begin{tabular}{|c|c|c|c|c|c|c|c|c|}
\hline $\begin{array}{l}\text { Profile } \\
\text { number }\end{array}$ & $\begin{array}{l}\text { Total } \\
\text { duration } \\
(\mathrm{min})\end{array}$ & $\begin{array}{l}\text { Pulse } 1 \\
\text { duration (min) }\end{array}$ & $\begin{array}{l}\text { Pulse } 1 \\
\text { Concen- } \\
\text { tration }^{\mathrm{a}}\end{array}$ & $\begin{array}{l}\text { Gap } \\
\text { duration } \\
\text { (min) }\end{array}$ & $\begin{array}{l}\text { Pulse } 2 \\
\text { duration ( } \mathrm{min} \text { ) }\end{array}$ & $\begin{array}{l}\text { Pulse } 2 \\
\text { concentration }^{\mathrm{b}}\end{array}$ & $\begin{array}{l}\mathrm{LC}_{50}(\text { pulse } 1 / \text { pulse } \\
2)(\mathrm{ppm})\end{array}$ & $\begin{array}{l}\mathrm{LCt}_{50} \text { (95\% confidence } \\
\text { interval) (ppm min) }\end{array}$ \\
\hline 1 & 5 & 5 & $\mathrm{Ci}$ & NA & NA & NA & $774 / \mathrm{NA}$ & $3871(3476-4267)$ \\
\hline 2 & 5 & 2.5 & $\mathrm{Ci}$ & 0 & 2.5 & $0.5 \times \mathrm{Ci}$ & $1068 / 534$ & $4005(3457-4553)$ \\
\hline 3 & 5 & 2.5 & $\mathrm{Ci}$ & 0 & 2.5 & $0.2 \times \mathrm{Ci}$ & $1339 / 268$ & $4018(3806-4230)$ \\
\hline 4 & 5 & 1.75 & $\mathrm{Ci}$ & 1.5 & 1.75 & $0.5 \times \mathrm{Ci}$ & $2012 / 1006$ & $5280(4233-6328)$ \\
\hline 5 & 5 & 1.75 & $\mathrm{Ci}$ & 1.5 & 1.75 & $0.2 \times \mathrm{Ci}$ & $2774 / 555$ & $5826(4813-6838)$ \\
\hline 6 & 30 & 30 & $\mathrm{Ci}$ & NA & NA & NA & 261/NA & $7841(7180-8501)$ \\
\hline 7 & 30 & 15 & $\mathrm{Ci}$ & 0 & 15 & $0.5 \times \mathrm{Ci}$ & $393 / 197$ & $8850(8042-9659)$ \\
\hline 8 & 30 & 15 & $\mathrm{Ci}$ & 0 & 15 & $0.2 \times \mathrm{Ci}$ & $415 / 83$ & $7463(6375-8551)$ \\
\hline 9 & 30 & 10.5 & $\mathrm{Ci}$ & 9 & 10.5 & $0.5 \times \mathrm{Ci}$ & $480 / 240$ & $7558(6128-8988)$ \\
\hline 10 & 30 & 10.5 & $\mathrm{Ci}$ & 9 & 10.5 & $0.2 \times \mathrm{Ci}$ & $591 / 118$ & 7445 (6770-8119) \\
\hline 11 & 15 & 15 & $\mathrm{Ci}$ & NA & NA & NA & 423/NA & $6340(5569-7111)$ \\
\hline
\end{tabular}

$\mathrm{NA}=$ not applicable.

a Each profile was run at least five times, with different initial concentrations (Ci). Initial concentrations differed among the 11 profiles.

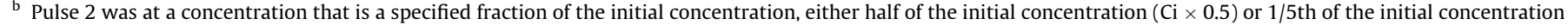
$(\mathrm{Ci} \times 0.2)$.

\section{References}

Department of Defense (DOD), 2005. Potential Military Chemical/Biological Agents and Compounds. Army Field Manual 3-11.9, Marine Corps Reference Publication 3-37.1B, Navy Tactical Reference Publication 3-11.32, Air Force Tactics, Techniques, and Procedures (Instruction) 3-2.55.

Haber, F.R., 1924. Zur Geschichte des Gaskrieges. In: Fünf Vortrage aus den Jahren 1920-1923. Springer, Berlin, pp. 76-92.
Health and Safety Executive, 2015. Toxicity levels of chemicals-assessment of the Dangerous Toxic Load (DTL) for Specified Level of Toxicity (SLOT) and Significant Likelihood of Death (SLOD), Bootle, Merseyside, United Kingdom. Available from <http://www.hse.gov.uk/chemicals/haztox.htm/> (accessed 04.02.15.).

Kaplan, H., 2009. A model for the toxic dose under time-varying concentration. J. Hazard. Mater. 167, 351-356.

Leuschner, J., Winkler, A., Leuschner, F., 1991. Toxicokinetic aspects of chronic cyanide exposure in the rat. Toxicol. Lett. 57, 195-201. 
Mannan, S. (Ed.), 2005. Toxic releases, Chapter 18 in Lee's Loss Prevention in the Process Industries, third ed. Elsevier Butterworth, Heinemann Ltd., Boston.

National Research Council, 2001. Standing Operating Procedures for Developing Acute Exposure Guideline Levels for Hazardous Chemicals. Subcommittee on Acute Exposure Guideline Levels, Committee on Toxicology, Board on Environmental Studies and Toxicology, Commission on Life Sciences. National Academies Press, Washington, DC.

National Research Council, 2002. Acute Exposure Guideline Levels for Selected Airborne Chemicals, vol. 2. Subcommittee on Acute Exposure Guideline Levels, Committee on Toxicology, Board on Environmental Studies and Toxicology, Commission on Life Sciences. National Academies Press, Washington, DC.

National Research Council, 2008. Combined exposures to hydrogen cyanide and carbon monoxide in Army operations: initial report. Committee on Combined Exposures to Hydrogen Cyanide and Carbon Monoxide, Committee on Toxicology, Board on Environmental Studies and Toxicology, Commission on Life Sciences. National Academies Press, Washington, DC.

Pauluhn, J., 2006. Acute head-only exposure of dogs to phosgene. Part III. Comparison of indicators of lung injury in dogs and rats. Inhal. Toxicol. 18, 609-621.

Pauluhn, J., 2015. Chapter 6. Time scaling of dose and time to response. The toxic load exponent. In: Salem, H., Katz, S.A. (Eds.), Inhalation Toxicology, third ed. CRC Press, Boca Raton, pp. 121-136.

Rao, P., Singh, P., Yadav, S.K., Gujar, N.L., Bhattacharya, R., 2013. Acute toxicity of some synthetic cyanogens in rats: time-dependent cyanide generation and cytochrome oxidase inhibition in soft tissues after sub-lethal oral intoxication. Food Chem. Toxicol. 59, 595-609.

Rhomberg, L.R., 2009. Uptake kinetics, species differences, and the determination of equivalent combinations of air concentration and exposure duration for the assessment of acute inhalation toxicity. Hum. Ecol. Risk Assess. 15, 1099-1145.

Ride, D.J., 1995. A practical method of estimating toxic loads in the presence of concentration fluctuations. Environmetrics 6, 643-650.

Saltzman, B.E., 1996. Assessment of health effects of fluctuating concentrations using simplified pharmacokinetic algorithms. J. Air Waste Manag. Assoc. 46, $1022-1034$.
Sommerville, D.R., Park, K.H., Kierzewski, M.O., Dunkel, M.D., Hutton, M.I., Pinto, N.A., 2006. Chapter 8: toxic load modeling. In: Salem, H., Katz, S.A. (Eds.) Inhalation Toxicology, second ed. CRC Press, Boca Raton, FL, pp. 137-158.

Sommerville, D.R., Bray, J.J., Reutter-Christy, S.A., Jablonski, R.E., Shelly, E.E., 2010 Review and assessment of chlorine mammalian lethality data and the development of a human estimate. Mil. Operations Res. 15 (3), 59-86.

Sousa, A.B., Manzano, H., Soto-Blanco, B., Górniak, S.L., 2003. Toxicokinetics of cyanide in rats, pigs and goats after oral dosing with potassium cyanide. Arch. Toxicol. 77, 330-334.

Stamyr, K., Nord, P., Johanson, G., 2008. Washout kinetics of inhaled hydrogen cyanide in breath. Toxicol. Lett. 179, 59-62.

Stamyr, K., Mörk, A.K., Johanson, G., 2014. Physiologically based pharmacokinetic modeling of hydrogen cyanide levels in human breath. Arch. Toxicol. (in press)

Sweeney, L.M., Sharits, B., Gargas, N.M., Doyle, T., Wong, B.A., James, R.A., 2013 Acute lethality of inhaled hydrogen cyanide in the laboratory rat: impact of concentration $\times$ time profile and evaluation of the predictivity of "toxic load" models. Technical Report NAMRU-D-13-35. Naval Medical Research Unit Dayton, Wright-Patterson Air Force Base, Ohio. URL: <http://www.dtic.mil/ dtic/tr/fulltext/us/a579551.pdf/>.

Sweeney, L.M., Sommerville, D.R., Channel, S.R., 2014. Impact of non-constant concentration exposure on lethality of inhaled hydrogen cyanide. Toxicol. Sci. 2014 (138), 205-216.

ten Berge, W.F., van Heemst, M.V., 1983. Validity and accuracy of a commonly used toxicity-assessment model in risk analysis. In: Fourth International Symposium on Loss Prevention and Safety Promotion in the Process Industries. vol. 1, Institute of Chemical Engineers, Rugby, p. I1.

ten Berge, W.F., Zwart, A., Appelman, L.M., 1986. Concentration-time mortality response relationship of irritant and systemically acting vapours and gases. J. Hazard. Mater. 13, 301-309.

U.S. Environmental Protection Agency (U.S. EPA), 2012. Benchmark Dose Technical Guidance. Risk Assessment Forum, U.S. EPA, Washington, DC. EPA/100/R-12/ 001.

Witschi, H.P., 1999. Some notes on the history of Haber's law. Toxicol. Sci. 50, 164 168. 


\section{Supplementary data}

Evaluating the validity and applicable domain of the toxic load model: impact of concentration vs. time profile on inhalation lethality of hydrogen cyanide

by Lisa M. Sweeney, Douglas R. Sommerville, Stephen R. Channel, Brian C. Sharits, Nathan M. Gargas, and Chester P. Gut, Jr.

Table S-1. Environmental Parameters

Profile 1

\begin{tabular}{|c|c|c|c|c|c|c|c|c|c|c|}
\hline $\begin{array}{l}\text { (Trial) } \\
\text { Exposure } \\
\text { Group }\end{array}$ & $\begin{array}{l}\text { Date } \\
\text { YYYYMMDD }\end{array}$ & $\begin{array}{l}\text { Data } \\
\text { Type }\end{array}$ & $\begin{array}{l}\text { Temp. } \\
\left({ }^{\circ} \mathbf{F}\right)\end{array}$ & $\begin{array}{l}\text { Temp. } \\
\left({ }^{\circ} \mathbf{C}\right)\end{array}$ & $\begin{array}{l}\text { Relative } \\
\text { Humidity } \\
\text { (percent) }\end{array}$ & $\begin{array}{l}\text { Static } \\
\text { Pressure } \\
\text { (inches } \\
\text { of } \\
\text { water) }\end{array}$ & $\begin{array}{l}\text { Pulse 1 } \\
\text { Air } \\
\text { Flow } \\
\text { (SLM) }\end{array}$ & $\begin{array}{l}\text { Pulse 1 } \\
\text { HCN } \\
\text { Flow } \\
\text { (SLM) }\end{array}$ & $\begin{array}{l}\text { Pulse 2 } \\
\text { Air } \\
\text { Flow } \\
\text { (SLM) }\end{array}$ & $\begin{array}{l}\text { Pulse 2 } \\
\text { HCN } \\
\text { Flow } \\
\text { (SLM) }\end{array}$ \\
\hline \multirow[t]{2}{*}{ (1) 2} & \multirow[t]{2}{*}{20130603} & Mean & 72.9 & 22.7 & 47.4 & -0.011 & 2.96 & 3.54 & N/A & N/A \\
\hline & & St. dev. & 0.1 & 0.0 & 0.7 & 0.002 & 0.00 & 0.00 & N/A & N/A \\
\hline \multirow[t]{2}{*}{ (2) 6} & \multirow[t]{2}{*}{20130604} & Mean & 72.7 & 22.6 & 38.0 & -0.012 & 1.55 & 4.95 & N/A & N/A \\
\hline & & St. dev. & 0.0 & 0.0 & 0.3 & 0.001 & 0.02 & 0.00 & N/A & N/A \\
\hline \multirow[t]{2}{*}{ (3) 27} & \multirow[t]{2}{*}{20130618} & Mean & 74.1 & 23.4 & 57.1 & -0.006 & 2.12 & 4.37 & N/A & N/A \\
\hline & & St. dev. & 0.2 & 0.1 & 0.6 & 0.001 & 0.00 & 0.00 & N/A & N/A \\
\hline \multirow[t]{2}{*}{ (4) 37} & \multirow[t]{2}{*}{20130625} & Mean & 74.3 & 23.5 & 62.7 & -0.007 & 2.41 & 4.08 & N/A & N/A \\
\hline & & St. dev. & 0.2 & 0.1 & 0.3 & 0.001 & 0.00 & 0.00 & N/A & N/A \\
\hline \multirow[t]{4}{*}{ (5) 50} & \multirow[t]{2}{*}{20130729} & Mean & 70.7 & 21.5 & 55.8 & -0.008 & 3.42 & 3.07 & N/A & N/A \\
\hline & & St. dev. & 0.2 & 0.1 & 0.4 & 0.001 & 0.00 & 0.00 & N/A & N/A \\
\hline & Minimum Mean & & 70.7 & 21.5 & 38.0 & -0.012 & & & & \\
\hline & Maximum Mean & & 74.3 & 23.5 & 62.7 & -0.006 & & & & \\
\hline
\end{tabular}


Profile 2

\begin{tabular}{|c|c|c|c|c|c|c|c|c|c|c|}
\hline $\begin{array}{l}\text { (Trial) } \\
\text { Exposure } \\
\text { Group }\end{array}$ & $\begin{array}{l}\text { Date } \\
\text { YYYYMMDD }\end{array}$ & $\begin{array}{l}\text { Data } \\
\text { Type }\end{array}$ & $\begin{array}{l}\text { Temp. } \\
\left({ }^{\circ} \mathbf{F}\right)\end{array}$ & $\begin{array}{l}\text { Temp. } \\
\left({ }^{\circ} \mathrm{C}\right)\end{array}$ & $\begin{array}{l}\text { Relative } \\
\text { Humidity } \\
\text { (percent) }\end{array}$ & $\begin{array}{l}\text { Static } \\
\text { Pressure } \\
\text { (inches } \\
\text { of water) }\end{array}$ & $\begin{array}{l}\text { Pulse 1 } \\
\text { Air } \\
\text { Flow } \\
\text { (SLM) }\end{array}$ & $\begin{array}{l}\text { Pulse } \\
1 \\
\text { HCN } \\
\text { Flow } \\
\text { (SLM) }\end{array}$ & $\begin{array}{l}\text { Pulse } \\
2 \text { Air } \\
\text { Flow } \\
\text { (SLM) }\end{array}$ & $\begin{array}{l}\text { Pulse 2 } \\
\text { HCN } \\
\text { Flow } \\
\text { (SLM) }\end{array}$ \\
\hline \multirow[t]{2}{*}{ (1) 12} & \multirow[t]{2}{*}{20130610} & Mean & 71.9 & 22.2 & 70.5 & -0.010 & 5.12 & 1.36 & 4.89 & 1.60 \\
\hline & & Std. dev. & 0.2 & 0.1 & 1.3 & 0.001 & 0.00 & 0.00 & 0.00 & 0.00 \\
\hline \multirow[t]{2}{*}{ (2) 21} & \multirow[t]{2}{*}{20130613} & Mean & 74.7 & 23.7 & 65.7 & -0.005 & 4.17 & 2.32 & 4.07 & 2.42 \\
\hline & & Std. dev. & 0.2 & 0.1 & 0.6 & 0.001 & 0.00 & 0.00 & 0.00 & 0.00 \\
\hline \multirow[t]{2}{*}{ (3) 29} & \multirow[t]{2}{*}{20130619} & Mean & 71.8 & 22.1 & 52.0 & -0.008 & 4.64 & 1.85 & 4.61 & 1.88 \\
\hline & & Std. dev. & 0.2 & 0.1 & 0.9 & 0.001 & 0.00 & 0.00 & 0.00 & 0.00 \\
\hline \multirow[t]{4}{*}{ (4) 34} & \multirow[t]{2}{*}{20130624} & Mean & 74.3 & 23.5 & 61.4 & -0.007 & 4.80 & 1.69 & 4.76 & 1.73 \\
\hline & & Std. dev. & 0.2 & 0.1 & 0.3 & 0.001 & 0.00 & 0.00 & 0.00 & 0.00 \\
\hline & \multicolumn{2}{|c|}{ Minimum Mean } & 71.8 & 22.1 & 52.0 & -0.010 & & & & \\
\hline & \multicolumn{2}{|c|}{ Maximum Mean } & 74.7 & 23.7 & 70.5 & -0.005 & & & & \\
\hline
\end{tabular}

Profile 3

\begin{tabular}{|c|c|c|c|c|c|c|c|c|c|c|}
\hline $\begin{array}{l}\text { (Trial) } \\
\text { Exposure } \\
\text { Group }\end{array}$ & $\begin{array}{l}\text { Date } \\
\text { YYYYMMDD }\end{array}$ & $\begin{array}{l}\text { Data } \\
\text { Type }\end{array}$ & $\begin{array}{l}\text { Temp. } \\
\left({ }^{\circ} \mathbf{F}\right)\end{array}$ & $\begin{array}{l}\text { Temp. } \\
\left({ }^{\circ} \mathrm{C}\right)\end{array}$ & $\begin{array}{l}\text { Relative } \\
\text { Humidity } \\
\text { (percent) }\end{array}$ & $\begin{array}{l}\text { Static } \\
\text { Pressure } \\
\text { (inches } \\
\text { of water) }\end{array}$ & $\begin{array}{l}\text { Pulse } 1 \\
\text { Air Flow } \\
\text { (SLM) }\end{array}$ & $\begin{array}{l}\text { Pulse } 1 \\
\text { HCN } \\
\text { Flow } \\
\text { (SLM) } \\
\end{array}$ & $\begin{array}{l}\text { Pulse } 2 \\
\text { Air Flow } \\
\text { (SLM) }\end{array}$ & $\begin{array}{l}\text { Pulse } 2 \\
\text { HCN } \\
\text { Flow } \\
\text { (SLM) } \\
\end{array}$ \\
\hline \multirow[t]{2}{*}{ (1) 7} & \multirow[t]{2}{*}{20130605} & Mean & 72.0 & 22.2 & 44.1 & -0.011 & 4.98 & 1.51 & 2.07 & 4.41 \\
\hline & & Std. dev. & 0.1 & 0.0 & 0.7 & 0.001 & 0.01 & 0.01 & 0.00 & 0.01 \\
\hline \multirow[t]{2}{*}{ (2) 15} & \multirow[t]{2}{*}{20130611} & Mean & 71.8 & 22.1 & 67.8 & -0.009 & 5.33 & 1.16 & 5.29 & 1.19 \\
\hline & & Std. dev. & 0.2 & 0.1 & 2.4 & 0.001 & 0.00 & 0.00 & 0.00 & 0.00 \\
\hline \multirow[t]{2}{*}{ (3) 30} & \multirow[t]{2}{*}{20130619} & Mean & 72.4 & 22.4 & 50.9 & -0.008 & 4.80 & 1.69 & 4.75 & 1.73 \\
\hline & & Std. dev. & 0.2 & 0.1 & 0.7 & 0.001 & 0.00 & 0.00 & 0.00 & 0.00 \\
\hline
\end{tabular}




\begin{tabular}{|c|c|c|c|c|c|c|c|c|c|c|}
\hline $\begin{array}{l}\text { (Trial) } \\
\text { Exposure } \\
\text { Group }\end{array}$ & $\begin{array}{l}\text { Date } \\
\text { YYYYMMDD }\end{array}$ & $\begin{array}{l}\text { Data } \\
\text { Type }\end{array}$ & $\begin{array}{l}\text { Temp. } \\
\left({ }^{\circ} \mathbf{F}\right)\end{array}$ & $\begin{array}{l}\text { Temp. } \\
\left({ }^{\circ} \mathrm{C}\right)\end{array}$ & $\begin{array}{l}\text { Relative } \\
\text { Humidity } \\
\text { (percent) }\end{array}$ & $\begin{array}{l}\text { Static } \\
\text { Pressure } \\
\text { (inches } \\
\text { of water) } \\
\end{array}$ & $\begin{array}{l}\text { Pulse } 1 \\
\text { Air Flow } \\
\text { (SLM) }\end{array}$ & $\begin{array}{l}\text { Pulse 1 } \\
\text { HCN } \\
\text { Flow } \\
\text { (SLM) } \\
\end{array}$ & $\begin{array}{l}\text { Pulse } 2 \\
\text { Air Flow } \\
\text { (SLM) }\end{array}$ & $\begin{array}{l}\text { Pulse } 2 \\
\text { HCN } \\
\text { Flow } \\
\text { (SLM) } \\
\end{array}$ \\
\hline \multirow[t]{4}{*}{ (4) 40} & \multirow[t]{2}{*}{20130626} & Mean & 75.0 & 23.9 & 61.1 & -0.006 & 5.17 & 1.31 & 5.13 & 1.36 \\
\hline & & Std. dev. & 0.2 & 0.1 & 0.4 & 0.001 & 0.00 & 0.00 & 0.00 & 0.00 \\
\hline & \multicolumn{2}{|c|}{ Minimum Mean } & 71.8 & 22.1 & 44.1 & -0.011 & & & & \\
\hline & \multicolumn{2}{|c|}{ Maximum Mean } & 75.0 & 23.9 & 67.8 & -0.006 & & & & \\
\hline
\end{tabular}

\section{Profile 4}

\begin{tabular}{|c|c|c|c|c|c|c|c|c|c|c|}
\hline $\begin{array}{l}\text { (Trial) } \\
\text { Exposure } \\
\text { Group }\end{array}$ & $\begin{array}{l}\text { Date } \\
\text { YYYYMMDD }\end{array}$ & $\begin{array}{l}\text { Data } \\
\text { Type }\end{array}$ & $\begin{array}{l}\text { Temp. } \\
\left({ }^{\circ} \mathbf{F}\right)\end{array}$ & $\begin{array}{l}\text { Temp. } \\
\left({ }^{\circ} \mathrm{C}\right)\end{array}$ & $\begin{array}{l}\text { Relative } \\
\text { Humidity } \\
\text { (percent) }\end{array}$ & $\begin{array}{l}\text { Static } \\
\text { Pressure } \\
\text { (inches } \\
\text { of water) }\end{array}$ & $\begin{array}{l}\text { Pulse 1 } \\
\text { Air Flow } \\
\text { (SLM) }\end{array}$ & $\begin{array}{l}\text { Pulse 1 } \\
\text { HCN } \\
\text { Flow } \\
\text { (SLM) }\end{array}$ & $\begin{array}{l}\text { Pulse } 2 \\
\text { Air Flow } \\
\text { (SLM) }\end{array}$ & $\begin{array}{l}\text { Pulse 2 } \\
\text { HCN } \\
\text { Flow } \\
\text { (SLM) }\end{array}$ \\
\hline \multirow[t]{2}{*}{ (1) 11} & \multirow[t]{2}{*}{20130606} & Mean & 72.5 & 22.5 & 60.1 & -0.009 & 3.80 & 2.69 & 3.45 & 3.04 \\
\hline & & Std. dev. & 0.2 & 0.1 & 0.7 & 0.001 & 0.01 & 0.01 & 0.01 & 0.00 \\
\hline \multirow{2}{*}{ (2) 20} & \multirow{2}{*}{20130612} & Mean & 73.9 & 23.3 & 64.9 & -0.006 & 2.89 & 3.59 & 2.88 & 3.61 \\
\hline & & Std. dev. & 0.1 & 0.1 & 0.4 & 0.001 & 0.00 & 0.00 & 0.00 & 0.00 \\
\hline \multirow[t]{2}{*}{ (3) 26} & \multirow[t]{2}{*}{20130618} & Mean & 73.6 & 23.1 & 59.5 & -0.007 & 3.30 & 3.19 & 3.27 & 3.21 \\
\hline & & Std. dev. & 0.2 & 0.1 & 1.0 & 0.001 & 0.00 & 0.00 & 0.00 & 0.00 \\
\hline \multirow[t]{2}{*}{ (4) 35} & \multirow[t]{2}{*}{20130624} & Mean & 74.8 & 23.8 & 61.5 & -0.005 & 3.49 & 3.00 & 3.45 & 3.04 \\
\hline & & Std. dev. & 0.2 & 0.1 & 0.6 & 0.001 & 0.00 & 0.00 & 0.00 & 0.00 \\
\hline \multirow[t]{2}{*}{ (5) 45} & \multirow[t]{2}{*}{20130701} & Mean & 73.4 & 23.0 & 58.7 & -0.007 & 3.67 & 2.82 & 3.59 & 2.89 \\
\hline & & Std. dev. & 0.2 & 0.1 & 0.4 & 0.001 & 0.00 & 0.00 & 0.00 & 0.00 \\
\hline \multirow[t]{2}{*}{ (6) 51} & \multirow[t]{2}{*}{20130729} & Mean & 71.3 & 21.8 & 54.4 & -0.007 & 4.13 & 2.35 & 4.06 & 2.43 \\
\hline & & Std. dev. & 0.2 & 0.1 & 0.4 & 0.001 & 0.00 & 0.00 & 0.00 & 0.00 \\
\hline \multirow[t]{2}{*}{ (7) 55} & \multirow[t]{2}{*}{20130731} & Mean & 73.4 & 23.0 & 59.3 & -0.005 & 4.45 & 2.03 & 4.37 & 2.11 \\
\hline & & Std. dev. & 0.2 & 0.1 & 0.7 & 0.001 & 0.00 & 0.00 & 0.00 & 0.00 \\
\hline
\end{tabular}




\begin{tabular}{|c|c|c|c|c|c|c|c|c|c|c|}
\hline \multirow[t]{2}{*}{ (8) 58} & \multirow[t]{2}{*}{20130827} & Mean & 72.7 & 22.6 & 61.8 & -0.006 & 4.75 & 1.74 & 1.11 & 5.37 \\
\hline & & Std. dev. & 0.1 & 0.1 & 0.5 & 0.001 & 0.00 & 0.00 & 0.00 & 0.00 \\
\hline & \multicolumn{2}{|c|}{ Minimum Mean } & 71.3 & 21.8 & 54.4 & -0.009 & & & & \\
\hline & \multicolumn{2}{|c|}{ Maximum Mean } & 74.8 & 23.8 & 64.9 & -0.005 & & & & \\
\hline
\end{tabular}

\section{Profile 5}

\begin{tabular}{|c|c|c|c|c|c|c|c|c|c|c|}
\hline $\begin{array}{l}\text { (Trial) } \\
\text { Exposure } \\
\text { Group }\end{array}$ & $\begin{array}{l}\text { Date } \\
\text { YYYYMMDD }\end{array}$ & $\begin{array}{l}\text { Data } \\
\text { Type }\end{array}$ & $\begin{array}{l}\text { Temp. } \\
\left({ }^{\circ} \mathbf{F}\right)\end{array}$ & $\begin{array}{l}\text { Temp. } \\
\left({ }^{\circ} \mathrm{C}\right)\end{array}$ & $\begin{array}{l}\text { Relative } \\
\text { Humidity } \\
\text { (percent) }\end{array}$ & $\begin{array}{l}\text { Static } \\
\text { Pressure } \\
\text { (inches } \\
\text { of water) }\end{array}$ & $\begin{array}{l}\text { Pulse } 1 \\
\text { Air Flow } \\
\text { (SLM) }\end{array}$ & $\begin{array}{l}\text { Pulse } 1 \\
\text { HCN } \\
\text { Flow } \\
\text { (SLM) } \\
\end{array}$ & $\begin{array}{l}\text { Pulse } 2 \\
\text { Air Flow } \\
\text { (SLM) }\end{array}$ & $\begin{array}{l}\text { Pulse 2 } \\
\text { HCN } \\
\text { Flow } \\
\text { (SLM) }\end{array}$ \\
\hline \multirow[t]{2}{*}{ (1) 8} & \multirow[t]{2}{*}{20130605} & Mean & 72.1 & 22.3 & 44.2 & -0.012 & 4.92 & 1.57 & 1.57 & 4.92 \\
\hline & & Std. dev. & 0.1 & 0.0 & 0.4 & 0.001 & 0.01 & 0.00 & 0.00 & 0.00 \\
\hline \multirow[t]{2}{*}{ (2) 14} & \multirow[t]{2}{*}{20130610} & Mean & 72.6 & 22.6 & 62.8 & -0.010 & 4.12 & 2.37 & 3.78 & 2.71 \\
\hline & & Std. dev. & 0.1 & 0.1 & 0.2 & 0.001 & 0.00 & 0.00 & 0.01 & 0.00 \\
\hline \multirow[t]{2}{*}{ (3) 25} & \multirow[t]{2}{*}{20130617} & Mean & 74.2 & 23.4 & 61.8 & -0.006 & 4.48 & 2.00 & 4.41 & 2.08 \\
\hline & & Std. dev. & 0.2 & 0.1 & 0.6 & 0.001 & 0.00 & 0.00 & 0.00 & 0.00 \\
\hline \multirow[t]{4}{*}{ (4) 41} & \multirow[t]{2}{*}{20130626} & Mean & 75.4 & 24.1 & 60.0 & -0.005 & 4.65 & 1.83 & 4.60 & 1.88 \\
\hline & & Std. dev. & 0.1 & 0.1 & 0.5 & 0.001 & 0.00 & 0.00 & 0.00 & 0.00 \\
\hline & \multicolumn{2}{|c|}{ Minimum Mean } & 72.1 & 22.3 & 44.2 & -0.012 & & & & \\
\hline & \multicolumn{2}{|c|}{ Maximum Mean } & 75.4 & 24.1 & 62.8 & -0.005 & & & & \\
\hline
\end{tabular}


Profile 6

\begin{tabular}{|c|c|c|c|c|c|c|c|c|c|c|}
\hline $\begin{array}{l}\text { (Trial) } \\
\text { Exposure } \\
\text { Group }\end{array}$ & $\begin{array}{l}\text { Date } \\
\text { YYYYMMDD }\end{array}$ & $\begin{array}{l}\text { Data } \\
\text { Type }\end{array}$ & $\begin{array}{l}\text { Temp. } \\
\left({ }^{\circ} \mathbf{F}\right)\end{array}$ & $\begin{array}{l}\text { Temp. } \\
\left({ }^{\circ} \mathrm{C}\right)\end{array}$ & $\begin{array}{l}\text { Relative } \\
\text { Humidity } \\
\text { (percent) }\end{array}$ & $\begin{array}{l}\text { Static } \\
\text { Pressure } \\
\text { (inches } \\
\text { of water) }\end{array}$ & $\begin{array}{l}\text { Pulse } 1 \\
\text { Air Flow } \\
\text { (SLM) }\end{array}$ & $\begin{array}{l}\text { Pulse 1 } \\
\text { HCN } \\
\text { Flow } \\
\text { (SLM) } \\
\end{array}$ & $\begin{array}{l}\text { Pulse } 2 \\
\text { Air Flow } \\
\text { (SLM) }\end{array}$ & $\begin{array}{l}\text { Pulse 2 } \\
\text { HCN } \\
\text { Flow } \\
\text { (SLM) } \\
\end{array}$ \\
\hline \multirow[t]{2}{*}{ (1) 1} & \multirow[t]{2}{*}{20130603} & Mean & 72.9 & 22.7 & 47.4 & -0.010 & 4.60 & 1.90 & $\mathrm{~N} / \mathrm{A}$ & N/A \\
\hline & & Std. dev. & 0.2 & 0.1 & 0.8 & 0.002 & 0.00 & 0.00 & $\mathrm{~N} / \mathrm{A}$ & N/A \\
\hline \multirow[t]{4}{*}{ (2) 18} & \multirow[t]{2}{*}{20130612} & Mean & 72.5 & 22.5 & 70.4 & -0.009 & 5.10 & 1.39 & $\mathrm{~N} / \mathrm{A}$ & N/A \\
\hline & & Std. dev. & 0.4 & 0.2 & 0.8 & 0.001 & 0.00 & 0.00 & $\mathrm{~N} / \mathrm{A}$ & $\mathrm{N} / \mathrm{A}$ \\
\hline & \multicolumn{2}{|l|}{ Minimum Mean } & 72.5 & 22.5 & 47.4 & -0.010 & & & & \\
\hline & \multicolumn{2}{|l|}{ Maximum Mean } & 72.9 & 22.7 & 70.4 & -0.009 & & & & \\
\hline
\end{tabular}

Profile 7

\begin{tabular}{|c|c|c|c|c|c|c|c|c|c|c|}
\hline $\begin{array}{l}\text { (Trial) } \\
\text { Exposure } \\
\text { Group }\end{array}$ & $\begin{array}{l}\text { Date } \\
\text { YYYYMMDD }\end{array}$ & $\begin{array}{l}\text { Data } \\
\text { Type }\end{array}$ & $\begin{array}{l}\text { Temp. } \\
\left({ }^{\circ} \mathbf{F}\right)\end{array}$ & $\begin{array}{l}\text { Temp. } \\
\left({ }^{\circ} \mathbf{C}\right)\end{array}$ & $\begin{array}{l}\text { Relative } \\
\text { Humidity } \\
\text { (percent) }\end{array}$ & $\begin{array}{l}\text { Static } \\
\text { Pressure } \\
\text { (inches } \\
\text { of water) }\end{array}$ & $\begin{array}{l}\text { Pulse } 1 \\
\text { Air Flow } \\
\text { (SLM) }\end{array}$ & $\begin{array}{l}\text { Pulse 1 } \\
\text { HCN } \\
\text { Flow } \\
\text { (SLM) }\end{array}$ & $\begin{array}{l}\text { Pulse } 2 \\
\text { Air Flow } \\
\text { (SLM) }\end{array}$ & $\begin{array}{l}\text { Pulse 2 } \\
\text { HCN } \\
\text { Flow } \\
\text { (SLM) }\end{array}$ \\
\hline \multirow[t]{2}{*}{ (1) 10} & \multirow[t]{2}{*}{20130606} & Mean & 72.0 & 22.2 & 60.3 & -0.010 & 5.74 & 0.74 & 5.72 & 0.77 \\
\hline & & Std. dev. & 0.2 & 0.1 & 0.5 & 0.001 & 0.01 & 0.00 & 0.01 & 0.01 \\
\hline \multirow[t]{2}{*}{ (2) 19} & \multirow[t]{2}{*}{20130612} & Mean & 73.4 & 23.0 & 68.9 & -0.008 & 5.90 & 0.59 & 5.89 & 0.60 \\
\hline & & Std. dev. & 0.3 & 0.2 & 1.1 & 0.001 & 0.00 & 0.00 & 0.00 & 0.00 \\
\hline \multirow[t]{2}{*}{ (3) 31} & \multirow[t]{2}{*}{20130619} & Mean & 72.9 & 22.7 & 48.9 & -0.008 & 5.59 & 0.90 & 5.60 & 0.89 \\
\hline & & Std. dev. & 0.2 & 0.1 & 0.7 & 0.001 & 0.00 & 0.00 & 0.00 & 0.00 \\
\hline \multirow[t]{2}{*}{ (4) 43} & \multirow[t]{2}{*}{20130627} & Mean & 74.2 & 23.5 & 61.2 & -0.007 & 5.81 & 0.68 & 4.46 & 2.03 \\
\hline & & Std. dev. & 0.3 & 0.2 & 0.7 & 0.001 & 0.00 & 0.00 & 0.00 & 0.00 \\
\hline \multirow[t]{2}{*}{ (5) 46} & \multirow[t]{2}{*}{20130701} & Mean & 74.2 & 23.5 & 57.0 & -0.007 & 5.96 & 0.53 & 5.96 & 0.53 \\
\hline & & Std. dev. & 0.2 & 0.1 & 0.6 & 0.001 & 0.00 & 0.00 & 0.00 & 0.00 \\
\hline
\end{tabular}




\begin{tabular}{|c|c|c|c|c|c|c|c|c|c|c|}
\hline \multirow[t]{2}{*}{ (6) 56} & \multirow[t]{2}{*}{20130826} & Mean & 71.6 & 22.0 & 57.7 & -0.007 & 6.04 & 0.45 & 5.12 & 1.36 \\
\hline & & Std. dev. & 0.3 & 0.2 & 0.4 & 0.002 & 0.00 & 0.00 & 0.00 & 0.00 \\
\hline & \multicolumn{2}{|c|}{ Minimum Mean } & 71.6 & 22.0 & 48.9 & -0.010 & & & & \\
\hline & \multicolumn{2}{|c|}{ Maximum Mean } & 74.2 & 23.5 & 68.9 & -0.007 & & & & \\
\hline
\end{tabular}

\section{Profile 8}

\begin{tabular}{|c|c|c|c|c|c|c|c|c|c|c|}
\hline $\begin{array}{l}\text { (Trial) } \\
\text { Exposure } \\
\text { Group }\end{array}$ & $\begin{array}{l}\text { Date } \\
\text { YYYYMMDD }\end{array}$ & $\begin{array}{l}\text { Data } \\
\text { Type }\end{array}$ & $\begin{array}{l}\text { Temp. } \\
\left({ }^{\circ} \mathbf{F}\right)\end{array}$ & $\begin{array}{l}\text { Temp. } \\
\left({ }^{\circ} \mathrm{C}\right)\end{array}$ & $\begin{array}{l}\text { Relative } \\
\text { Humidity } \\
\text { (percent) }\end{array}$ & $\begin{array}{l}\text { Static } \\
\text { Pressure } \\
\text { (inches } \\
\text { of water) }\end{array}$ & $\begin{array}{l}\text { Pulse } 1 \\
\text { Air Flow } \\
\text { (SLM) }\end{array}$ & $\begin{array}{l}\text { Pulse } 1 \\
\text { HCN } \\
\text { Flow } \\
\text { (SLM) } \\
\end{array}$ & $\begin{array}{l}\text { Pulse } 2 \\
\text { Air Flow } \\
\text { (SLM) }\end{array}$ & $\begin{array}{l}\text { Pulse 2 } \\
\text { HCN } \\
\text { Flow } \\
\text { (SLM) }\end{array}$ \\
\hline \multirow[t]{2}{*}{ (1) 5} & \multirow[t]{2}{*}{20130604} & Mean & 72.5 & 22.5 & 39.0 & -0.011 & 5.89 & 0.60 & 5.89 & 0.60 \\
\hline & & Std. dev. & 0.3 & 0.1 & 0.9 & 0.001 & 0.00 & 0.00 & 0.00 & 0.00 \\
\hline \multirow[t]{2}{*}{ (2) 16} & \multirow[t]{2}{*}{20130611} & Mean & 72.6 & 22.5 & 63.2 & -0.007 & 6.03 & 0.46 & 6.03 & 0.46 \\
\hline & & Std. dev. & 0.2 & 0.1 & 0.8 & 0.001 & 0.00 & 0.00 & 0.00 & 0.00 \\
\hline \multirow[t]{2}{*}{ (3) 28} & \multirow[t]{2}{*}{20130618} & Mean & 74.6 & 23.7 & 55.0 & -0.007 & 6.09 & 0.41 & 6.09 & 0.40 \\
\hline & & Std. dev. & 0.2 & 0.1 & 0.6 & 0.001 & 0.00 & 0.00 & 0.00 & 0.00 \\
\hline \multirow[t]{4}{*}{ (4) 42} & \multirow[t]{2}{*}{20130626} & Mean & 75.7 & 24.3 & 58.8 & -0.006 & 5.79 & 0.70 & 5.78 & 0.71 \\
\hline & & Std. dev. & 0.2 & 0.1 & 1.1 & 0.001 & 0.00 & 0.00 & 0.00 & 0.00 \\
\hline & \multicolumn{2}{|c|}{ Minimum Mean } & 72.5 & 22.5 & 39.0 & -0.011 & & & & \\
\hline & \multicolumn{2}{|c|}{ Maximum Mean } & 75.7 & 24.3 & 63.2 & -0.006 & & & & \\
\hline
\end{tabular}


Profile 9

\begin{tabular}{|c|c|c|c|c|c|c|c|c|c|c|}
\hline $\begin{array}{l}\text { (Trial) } \\
\text { Exposure } \\
\text { Group }\end{array}$ & $\begin{array}{l}\text { Date } \\
\text { YYYYMMDD }\end{array}$ & $\begin{array}{l}\text { Data } \\
\text { Type }\end{array}$ & $\begin{array}{l}\text { Temp. } \\
\left({ }^{\circ} \mathbf{F}\right)\end{array}$ & $\begin{array}{l}\text { Temp. } \\
\left({ }^{\circ} \mathrm{C}\right)\end{array}$ & $\begin{array}{l}\text { Relative } \\
\text { Humidity } \\
\text { (percent) }\end{array}$ & $\begin{array}{l}\text { Static } \\
\text { Pressure } \\
\text { (inches } \\
\text { of water) }\end{array}$ & $\begin{array}{l}\text { Pulse } 1 \\
\text { Air Flow } \\
\text { (SLM) }\end{array}$ & $\begin{array}{l}\text { Pulse } 1 \\
\text { HCN } \\
\text { Flow } \\
\text { (SLM) }\end{array}$ & $\begin{array}{l}\text { Pulse } 2 \\
\text { Air Flow } \\
\text { (SLM) }\end{array}$ & $\begin{array}{l}\text { Pulse 2 } \\
\text { HCN } \\
\text { Flow } \\
\text { (SLM) }\end{array}$ \\
\hline \multirow[t]{2}{*}{ (1) 13} & \multirow{2}{*}{20130610} & Mean & 72.5 & 22.5 & 64.0 & -0.010 & 5.48 & 1.01 & 5.36 & 1.12 \\
\hline & & Std. dev. & 0.2 & 0.1 & 1.5 & 0.001 & 0.00 & 0.00 & 0.00 & 0.00 \\
\hline \multirow[t]{2}{*}{ (2) 22} & \multirow[t]{2}{*}{20130613} & Mean & 75.4 & 24.1 & 62.3 & -0.006 & 5.60 & 0.89 & 5.41 & 0.92 \\
\hline & & Std. dev. & 0.2 & 0.1 & 0.9 & 0.001 & 0.00 & 0.00 & 0.89 & 0.00 \\
\hline \multirow[t]{2}{*}{ (3) 32} & \multirow[t]{2}{*}{20130620} & Mean & 71.6 & 22.0 & 51.4 & -0.009 & 5.50 & 0.99 & 5.49 & 1.00 \\
\hline & & Std. dev. & 0.3 & 0.2 & 0.5 & 0.001 & 0.00 & 0.00 & 0.00 & 0.00 \\
\hline \multirow[t]{2}{*}{ (4) 36} & \multirow[t]{2}{*}{20130624} & Mean & 75.5 & 24.1 & 59.6 & -0.006 & 5.66 & 0.83 & 5.65 & 0.84 \\
\hline & & Std. dev. & 0.2 & 0.1 & 1.1 & 0.001 & 0.00 & 0.00 & 0.00 & 0.00 \\
\hline \multirow[t]{2}{*}{ (5) 44} & \multirow[t]{2}{*}{20130627} & Mean & 74.9 & 23.9 & 60.8 & -0.008 & 5.55 & 0.94 & 3.66 & 2.82 \\
\hline & & Std. dev. & 0.1 & 0.0 & 1.0 & 0.001 & 0.00 & 0.00 & 0.00 & 0.00 \\
\hline \multirow[t]{2}{*}{ (6) 47} & \multirow[t]{2}{*}{20130701} & Mean & 74.5 & 23.6 & 55.8 & -0.007 & 5.28 & 1.21 & 5.24 & 1.25 \\
\hline & & Std. dev. & 0.2 & 0.1 & 0.4 & 0.001 & 0.00 & 0.00 & 0.00 & 0.00 \\
\hline \multirow[t]{4}{*}{ (7) 53} & \multirow[t]{2}{*}{20130730} & Mean & 72.2 & 22.3 & 57.7 & -0.007 & 5.54 & 0.94 & 5.53 & 0.96 \\
\hline & & Std. dev. & 0.3 & 0.2 & 0.5 & 0.001 & 0.00 & 0.00 & 0.00 & 0.00 \\
\hline & \multicolumn{2}{|l|}{ Minimum Mean } & 71.6 & 22.0 & 51.4 & -0.010 & & & & \\
\hline & \multicolumn{2}{|l|}{ Maximum Mean } & 75.5 & 24.1 & 64.0 & -0.006 & & & & \\
\hline
\end{tabular}


Profile 10

\begin{tabular}{|c|c|c|c|c|c|c|c|c|c|c|}
\hline $\begin{array}{l}\text { (Trial) } \\
\text { Exposure } \\
\text { Group }\end{array}$ & $\begin{array}{l}\text { Date } \\
\text { YYYYMMDD }\end{array}$ & $\begin{array}{l}\text { Data } \\
\text { Type }\end{array}$ & $\begin{array}{l}\text { Temp. } \\
\left({ }^{\circ} \mathbf{F}\right)\end{array}$ & $\begin{array}{l}\text { Temp. } \\
\left({ }^{\circ} \mathrm{C}\right)\end{array}$ & $\begin{array}{l}\text { Relative } \\
\text { Humidity } \\
\text { (percent) }\end{array}$ & $\begin{array}{l}\text { Static } \\
\text { Pressure } \\
\text { (inches } \\
\text { of water) }\end{array}$ & $\begin{array}{l}\text { Pulse } 1 \\
\text { Air Flow } \\
\text { (SLM) }\end{array}$ & $\begin{array}{l}\text { Pulse } 1 \\
\text { HCN } \\
\text { Flow } \\
\text { (SLM) } \\
\end{array}$ & $\begin{array}{l}\text { Pulse } 2 \\
\text { Air Flow } \\
\text { (SLM) }\end{array}$ & $\begin{array}{l}\text { Pulse 2 } \\
\text { HCN } \\
\text { Flow } \\
\text { (SLM) }\end{array}$ \\
\hline \multirow[t]{2}{*}{ (1) 9} & \multirow[t]{2}{*}{20130605} & Mean & 72.2 & 22.3 & 44.5 & -0.012 & 5.74 & 0.75 & 4.02 & 2.47 \\
\hline & & Std. dev. & 0.1 & 0.1 & 0.6 & 0.000 & 0.00 & 0.00 & 0.01 & 0.01 \\
\hline \multirow[t]{2}{*}{ (2) 17} & \multirow[t]{2}{*}{20130611} & Mean & 72.8 & 22.7 & 62.5 & -0.008 & 5.37 & 1.12 & 5.34 & 1.15 \\
\hline & & Std. dev. & 0.2 & 0.1 & 0.3 & 0.001 & 0.00 & 0.00 & 0.00 & 0.00 \\
\hline \multirow[t]{2}{*}{ (3) 24} & \multirow[t]{2}{*}{20130617} & Mean & 73.9 & 23.3 & 62.9 & -0.005 & 5.79 & 0.70 & 5.79 & 0.70 \\
\hline & & Std. dev. & 0.2 & 0.1 & 0.6 & 0.001 & 0.00 & 0.00 & 0.00 & 0.00 \\
\hline \multirow[t]{2}{*}{ (4) 39} & \multirow[t]{2}{*}{20130625} & Mean & 75.2 & 24.0 & 59.8 & -0.006 & 5.48 & 1.00 & 5.47 & 1.02 \\
\hline & & Std. dev. & 0.2 & 0.1 & 1.0 & 0.002 & 0.00 & 0.01 & 0.00 & 0.00 \\
\hline \multirow[t]{2}{*}{ (5) 48} & \multirow[t]{2}{*}{20130702} & Mean & 73.6 & 23.1 & 58.8 & -0.007 & 5.87 & 0.62 & 5.86 & 0.63 \\
\hline & & Std. dev. & 0.3 & 0.1 & 0.6 & 0.001 & 0.00 & 0.00 & 0.00 & 0.00 \\
\hline \multirow[t]{2}{*}{ (6) 54} & \multirow[t]{2}{*}{20130731} & Mean & 72.7 & 22.6 & 63.3 & -0.006 & 5.95 & 0.54 & 5.94 & 0.55 \\
\hline & & Std. dev. & 0.4 & 0.2 & 0.7 & 0.001 & 0.00 & 0.00 & 0.00 & 0.00 \\
\hline \multirow[t]{2}{*}{ (7) 57} & \multirow{2}{*}{20130826} & Mean & 72.3 & 22.4 & 57.5 & -0.008 & 5.58 & 0.90 & 3.76 & 2.73 \\
\hline & & Std. dev. & 0.2 & 0.1 & 0.9 & 0.001 & 0.00 & 0.00 & 0.00 & 0.00 \\
\hline \multirow[t]{2}{*}{ (8) 59} & \multirow[t]{2}{*}{20130828} & Mean & 74.2 & 23.4 & 62.0 & -0.005 & 5.87 & 0.62 & 4.61 & 1.87 \\
\hline & & Std. dev. & 0.2 & 0.1 & 0.7 & 0.002 & 0.00 & 0.00 & 0.00 & 0.00 \\
\hline \multirow[t]{4}{*}{ (9) 60} & \multirow[t]{2}{*}{20130829} & Mean & 73.6 & 23.1 & 62.7 & -0.005 & 6.00 & 0.49 & 5.01 & 1.48 \\
\hline & & Std. dev. & 0.3 & 0.2 & 0.6 & 0.001 & 0.00 & 0.00 & 0.00 & 0.00 \\
\hline & \multicolumn{2}{|l|}{ Minimum Mean } & 72.2 & 22.3 & 44.5 & -0.012 & & & & \\
\hline & \multicolumn{2}{|c|}{ Maximum Mean } & 75.2 & 24.0 & 63.3 & -0.005 & & & & \\
\hline
\end{tabular}




\section{Profile 11}

\begin{tabular}{|c|c|c|c|c|c|c|c|c|c|c|}
\hline $\begin{array}{l}\text { (Trial) } \\
\text { Exposure } \\
\text { Group }\end{array}$ & $\begin{array}{l}\text { Date } \\
\text { YYYYMMDD }\end{array}$ & $\begin{array}{l}\text { Data } \\
\text { Type }\end{array}$ & $\begin{array}{l}\text { Temp. } \\
\left({ }^{\circ} \mathbf{F}\right)\end{array}$ & $\begin{array}{l}\text { Temp. } \\
\left({ }^{\circ} \mathbf{C}\right)\end{array}$ & $\begin{array}{l}\text { Relative } \\
\text { Humidity } \\
\text { (percent) }\end{array}$ & $\begin{array}{l}\text { Static } \\
\text { Pressure } \\
\text { (inches } \\
\text { of water) }\end{array}$ & $\begin{array}{l}\text { Pulse } 1 \\
\text { Air Flow } \\
\text { (SLM) }\end{array}$ & $\begin{array}{l}\text { Pulse 1 } \\
\text { HCN } \\
\text { Flow } \\
\text { (SLM) } \\
\end{array}$ & $\begin{array}{l}\text { Pulse } 2 \\
\text { Air Flow } \\
\text { (SLM) }\end{array}$ & $\begin{array}{l}\text { Pulse 2 } \\
\text { HCN } \\
\text { Flow } \\
\text { (SLM) }\end{array}$ \\
\hline \multirow[t]{2}{*}{ (1) 3} & \multirow[t]{2}{*}{20130603} & Mean & 72.5 & 22.5 & 48.2 & -0.010 & 2.41 & 4.08 & N/A & N/A \\
\hline & & Std. dev. & 0.1 & 0.0 & 0.4 & 0.001 & 0.00 & 0.00 & N/A & N/A \\
\hline \multirow[t]{2}{*}{ (2) 4} & \multirow[t]{2}{*}{20130604} & Mean & 71.9 & 22.2 & 41.7 & -0.011 & 3.25 & 3.24 & N/A & N/A \\
\hline & & Std. dev. & 0.1 & 0.1 & 0.8 & 0.001 & 0.00 & 0.00 & N/A & N/A \\
\hline \multirow[t]{2}{*}{ (3) 23} & \multirow[t]{2}{*}{20130617} & Mean & 73.1 & 22.9 & 64.1 & -0.007 & 2.45 & 4.03 & N/A & N/A \\
\hline & & Std. dev. & 0.2 & 0.1 & 0.5 & 0.001 & 0.00 & 0.00 & N/A & N/A \\
\hline \multirow[t]{2}{*}{ (4) 33} & \multirow[t]{2}{*}{20130620} & Mean & 72.5 & 22.5 & 52.6 & -0.009 & 3.61 & 2.88 & N/A & N/A \\
\hline & & Std. dev. & 0.2 & 0.1 & 0.3 & 0.001 & 0.00 & 0.00 & N/A & N/A \\
\hline \multirow[t]{2}{*}{ (5) 38} & \multirow{2}{*}{20130625} & Mean & 74.8 & 23.8 & 61.2 & -0.006 & 4.12 & 2.36 & N/A & N/A \\
\hline & & Std. dev. & 0.1 & 0.1 & 0.4 & 0.001 & 0.00 & 0.00 & N/A & N/A \\
\hline \multirow[t]{2}{*}{ (6) 49} & \multirow[t]{2}{*}{20130702} & Mean & 74.0 & 23.4 & 58.4 & -0.007 & 3.60 & 2.89 & N/A & N/A \\
\hline & & Std. dev. & 0.2 & 0.1 & 0.3 & 0.002 & 0.00 & 0.00 & N/A & N/A \\
\hline \multirow[t]{4}{*}{ (7) 52} & \multirow[t]{2}{*}{20130730} & Mean & 71.2 & 21.8 & 58.4 & -0.007 & 4.38 & 2.10 & N/A & N/A \\
\hline & & Std. dev. & 0.2 & 0.1 & 0.5 & 0.001 & 0.00 & 0.00 & N/A & N/A \\
\hline & \multicolumn{2}{|l|}{ Minimum Mean } & 71.2 & 21.8 & 41.7 & -0.011 & & & & \\
\hline & \multicolumn{2}{|c|}{ Maximum Mean } & 74.8 & 23.8 & 64.1 & -0.006 & & & & \\
\hline
\end{tabular}


Table S-2. Individual Animal Data

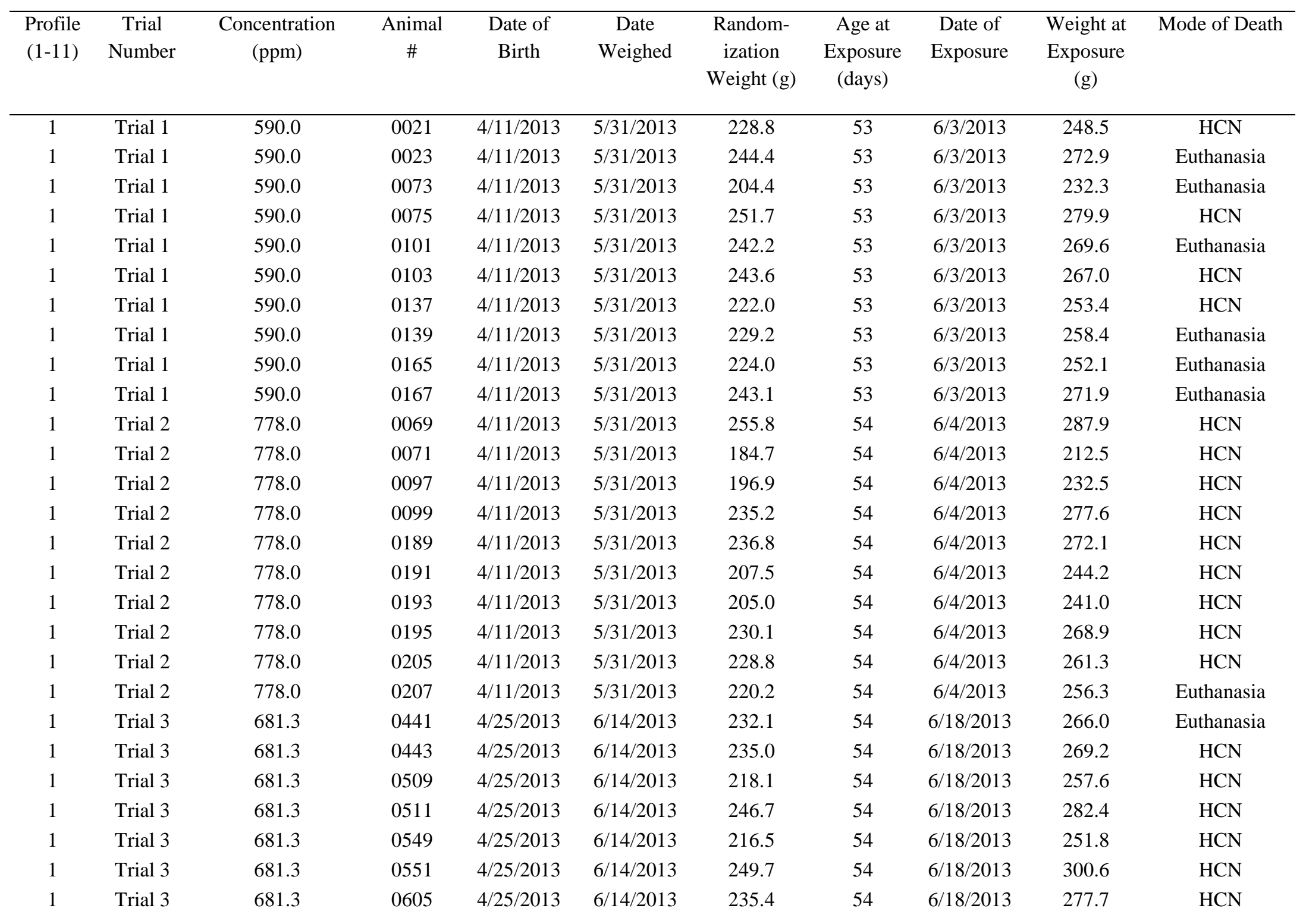




\begin{tabular}{|c|c|c|c|c|c|c|c|c|c|c|}
\hline $\begin{array}{l}\text { Profile } \\
(1-11)\end{array}$ & $\begin{array}{c}\text { Trial } \\
\text { Number }\end{array}$ & $\begin{array}{c}\text { Concentration } \\
(\mathrm{ppm})\end{array}$ & $\begin{array}{c}\text { Animal } \\
\#\end{array}$ & $\begin{array}{l}\text { Date of } \\
\text { Birth }\end{array}$ & $\begin{array}{c}\text { Date } \\
\text { Weighed }\end{array}$ & $\begin{array}{c}\text { Random- } \\
\text { ization } \\
\text { Weight (g) }\end{array}$ & $\begin{array}{c}\text { Age at } \\
\text { Exposure } \\
\text { (days) }\end{array}$ & $\begin{array}{c}\text { Date of } \\
\text { Exposure }\end{array}$ & $\begin{array}{c}\text { Weight at } \\
\text { Exposure } \\
\text { (g) }\end{array}$ & Mode of Death \\
\hline 1 & Trial 3 & 681.3 & 0607 & $4 / 25 / 2013$ & $6 / 14 / 2013$ & 232.7 & 54 & $6 / 18 / 2013$ & 269.5 & Euthanasia \\
\hline 1 & Trial 3 & 681.3 & 0617 & $4 / 25 / 2013$ & $6 / 14 / 2013$ & 236.0 & 54 & $6 / 18 / 2013$ & 266.0 & $\mathrm{HCN}$ \\
\hline 1 & Trial 3 & 681.3 & 0619 & $4 / 25 / 2013$ & $6 / 14 / 2013$ & 226.9 & 54 & $6 / 18 / 2013$ & 266.4 & $\mathrm{HCN}$ \\
\hline 1 & Trial 4 & 642.5 & 0701 & $5 / 2 / 2013$ & $6 / 21 / 2013$ & 237.3 & 54 & $6 / 25 / 2013$ & 272.0 & $\mathrm{HCN}$ \\
\hline 1 & Trial 4 & 642.5 & 0703 & $5 / 2 / 2013$ & $6 / 21 / 2013$ & 241.9 & 54 & $6 / 25 / 2013$ & 279.0 & Euthanasia \\
\hline 1 & Trial 4 & 642.5 & 0709 & $5 / 2 / 2013$ & $6 / 21 / 2013$ & 250.8 & 54 & $6 / 25 / 2013$ & 294.7 & $\mathrm{HCN}$ \\
\hline 1 & Trial 4 & 642.5 & 0711 & $5 / 2 / 2013$ & $6 / 21 / 2013$ & 229.2 & 54 & $6 / 25 / 2013$ & 274.7 & Euthanasia \\
\hline 1 & Trial 4 & 642.5 & 0749 & $5 / 2 / 2013$ & $6 / 21 / 2013$ & 237.8 & 54 & $6 / 25 / 2013$ & 271.9 & $\mathrm{HCN}$ \\
\hline 1 & Trial 4 & 642.5 & 0751 & $5 / 2 / 2013$ & $6 / 21 / 2013$ & 239.1 & 54 & $6 / 25 / 2013$ & 279.9 & $\mathrm{HCN}$ \\
\hline 1 & Trial 4 & 642.5 & 0821 & $5 / 2 / 2013$ & $6 / 21 / 2013$ & 229.9 & 54 & $6 / 25 / 2013$ & 259.3 & Euthanasia \\
\hline 1 & Trial 4 & 642.5 & 0823 & $5 / 2 / 2013$ & $6 / 21 / 2013$ & 245.1 & 54 & $6 / 25 / 2013$ & 282.9 & $\mathrm{HCN}$ \\
\hline 1 & Trial 4 & 642.5 & 0865 & $5 / 2 / 2013$ & $6 / 21 / 2013$ & 224.4 & 54 & $6 / 25 / 2013$ & 256.6 & Euthanasia \\
\hline 1 & Trial 4 & 642.5 & 0867 & $5 / 2 / 2013$ & $6 / 21 / 2013$ & 246.9 & 54 & $6 / 25 / 2013$ & 282.3 & Euthanasia \\
\hline 1 & Trial 5 & 489.3 & 0981 & 6/6/2013 & $7 / 26 / 2013$ & 229.1 & 53 & $7 / 29 / 2013$ & 257.5 & Euthanasia \\
\hline 1 & Trial 5 & 489.3 & 0983 & $6 / 6 / 2013$ & $7 / 26 / 2013$ & 220.7 & 53 & $7 / 29 / 2013$ & 246.8 & $\mathrm{HCN}$ \\
\hline 1 & Trial 5 & 489.3 & 0993 & $6 / 6 / 2013$ & $7 / 26 / 2013$ & 224.2 & 53 & $7 / 29 / 2013$ & 255.6 & Euthanasia \\
\hline 1 & Trial 5 & 489.3 & 0995 & 6/6/2013 & $7 / 26 / 2013$ & 220.6 & 53 & $7 / 29 / 2013$ & 247.6 & Euthanasia \\
\hline 1 & Trial 5 & 489.3 & 0997 & $6 / 6 / 2013$ & $7 / 26 / 2013$ & 222.9 & 53 & $7 / 29 / 2013$ & 248.8 & Euthanasia \\
\hline 1 & Trial 5 & 489.3 & 0999 & $6 / 6 / 2013$ & $7 / 26 / 2013$ & 224.8 & 53 & $7 / 29 / 2013$ & 253.9 & Euthanasia \\
\hline 1 & Trial 5 & 489.3 & 1021 & $6 / 6 / 2013$ & $7 / 26 / 2013$ & 226.9 & 53 & $7 / 29 / 2013$ & 253.4 & Euthanasia \\
\hline 1 & Trial 5 & 489.3 & 1023 & $6 / 6 / 2013$ & $7 / 26 / 2013$ & 227.7 & 53 & $7 / 29 / 2013$ & 257.3 & Euthanasia \\
\hline 1 & Trial 5 & 489.3 & 1069 & $6 / 6 / 2013$ & $7 / 26 / 2013$ & 223.4 & 53 & $7 / 29 / 2013$ & 253.2 & Euthanasia \\
\hline 1 & Trial 5 & 489.3 & 1071 & 6/6/2013 & $7 / 26 / 2013$ & 239.4 & 53 & 7/29/2013 & 273.3 & $\mathrm{HCN}$ \\
\hline 2 & Trial 1 & $234.2 / 1175.3$ & 0257 & $4 / 18 / 2013$ & $6 / 7 / 2013$ & 225.8 & 53 & $6 / 10 / 2013$ & 251.8 & Euthanasia \\
\hline 2 & Trial 1 & $234.2 / 1175.3$ & 0259 & $4 / 18 / 2013$ & $6 / 7 / 2013$ & 249.3 & 53 & $6 / 10 / 2013$ & 278.9 & Euthanasia \\
\hline 2 & Trial 1 & $234.2 / 1175.3$ & 0393 & $4 / 18 / 2013$ & $6 / 7 / 2013$ & 230.0 & 53 & $6 / 10 / 2013$ & 257.8 & Euthanasia \\
\hline 2 & Trial 1 & $234.2 / 1175.3$ & 0395 & $4 / 18 / 2013$ & $6 / 7 / 2013$ & 244.0 & 53 & $6 / 10 / 2013$ & 272.5 & Euthanasia \\
\hline 2 & Trial 1 & $234.2 / 1175.3$ & 0401 & $4 / 18 / 2013$ & 6/7/2013 & 226.8 & 53 & $6 / 10 / 2013$ & 249.9 & Euthanasia \\
\hline
\end{tabular}




\begin{tabular}{|c|c|c|c|c|c|c|c|c|c|c|}
\hline $\begin{array}{l}\text { Profile } \\
(1-11)\end{array}$ & $\begin{array}{c}\text { Trial } \\
\text { Number }\end{array}$ & $\begin{array}{c}\text { Concentration } \\
(\mathrm{ppm})\end{array}$ & $\begin{array}{c}\text { Animal } \\
\#\end{array}$ & $\begin{array}{l}\text { Date of } \\
\text { Birth }\end{array}$ & $\begin{array}{c}\text { Date } \\
\text { Weighed }\end{array}$ & $\begin{array}{c}\text { Random- } \\
\text { ization } \\
\text { Weight (g) }\end{array}$ & $\begin{array}{c}\text { Age at } \\
\text { Exposure } \\
\text { (days) }\end{array}$ & $\begin{array}{c}\text { Date of } \\
\text { Exposure }\end{array}$ & $\begin{array}{c}\text { Weight at } \\
\text { Exposure } \\
\text { (g) }\end{array}$ & Mode of Death \\
\hline 2 & Trial 1 & $234.2 / 1175.3$ & 0403 & $4 / 18 / 2013$ & $6 / 7 / 2013$ & 242.4 & 53 & $6 / 10 / 2013$ & 271.9 & Euthanasia \\
\hline 2 & Trial 1 & $234.2 / 1175.3$ & 0405 & $4 / 18 / 2013$ & 6/7/2013 & 245.1 & 53 & $6 / 10 / 2013$ & 274.5 & $\mathrm{HCN}$ \\
\hline 2 & Trial 1 & $234.2 / 1175.3$ & 0407 & $4 / 18 / 2013$ & $6 / 7 / 2013$ & 233.3 & 53 & $6 / 10 / 2013$ & 263.6 & Euthanasia \\
\hline 2 & Trial 1 & $234.2 / 1175.3$ & 0437 & $4 / 18 / 2013$ & 6/7/2013 & 249.4 & 53 & $6 / 10 / 2013$ & 278.3 & Euthanasia \\
\hline 2 & Trial 1 & $234.2 / 1175.3$ & 0439 & $4 / 18 / 2013$ & 6/7/2013 & 253.8 & 53 & $6 / 10 / 2013$ & 287.4 & $\mathrm{HCN}$ \\
\hline 2 & Trial 2 & $357.6 / 1780.0$ & 0245 & $4 / 18 / 2013$ & 6/7/2013 & 213.0 & 56 & $6 / 13 / 2013$ & 267.0 & $\mathrm{HCN}$ \\
\hline 2 & Trial 2 & $357.6 / 1780.0$ & 0247 & $4 / 18 / 2013$ & $6 / 7 / 2013$ & 211.6 & 56 & $6 / 13 / 2013$ & 270.1 & $\mathrm{HCN}$ \\
\hline 2 & Trial 2 & $357.6 / 1780.0$ & 0313 & $4 / 18 / 2013$ & $6 / 7 / 2013$ & 209.4 & 56 & $6 / 13 / 2013$ & 263.7 & $\mathrm{HCN}$ \\
\hline 2 & Trial 2 & $357.6 / 1780.0$ & 0315 & $4 / 18 / 2013$ & $6 / 7 / 2013$ & 202.2 & 56 & $6 / 13 / 2013$ & 252.6 & $\mathrm{HCN}$ \\
\hline 2 & Trial 2 & $357.6 / 1780.0$ & 0349 & $4 / 18 / 2013$ & 6/7/2013 & 205.7 & 56 & $6 / 13 / 2013$ & 259.1 & $\mathrm{HCN}$ \\
\hline 2 & Trial 2 & $357.6 / 1780.0$ & 0351 & $4 / 18 / 2013$ & 6/7/2013 & 202.6 & 56 & $6 / 13 / 2013$ & 251.2 & $\mathrm{HCN}$ \\
\hline 2 & Trial 2 & $357.6 / 1780.0$ & 0353 & $4 / 18 / 2013$ & $6 / 7 / 2013$ & 229.3 & 56 & $6 / 13 / 2013$ & 277.9 & Euthanasia \\
\hline 2 & Trial 2 & $357.6 / 1780.0$ & 0355 & $4 / 18 / 2013$ & $6 / 7 / 2013$ & 198.7 & 56 & $6 / 13 / 2013$ & 252.4 & $\mathrm{HCN}$ \\
\hline 2 & Trial 2 & $357.6 / 1780.0$ & 0429 & $4 / 18 / 2013$ & 6/7/2013 & 198.6 & 56 & $6 / 13 / 2013$ & 246.2 & $\mathrm{HCN}$ \\
\hline 2 & Trial 2 & $357.6 / 1780.0$ & 0431 & $4 / 18 / 2013$ & 6/7/2013 & 222.7 & 56 & $6 / 13 / 2013$ & 276.1 & $\mathrm{HCN}$ \\
\hline 2 & Trial 3 & 297.7/1442.6 & 0541 & $4 / 25 / 2013$ & $6 / 14 / 2013$ & 235.5 & 55 & $6 / 19 / 2013$ & 279.7 & $\mathrm{HCN}$ \\
\hline 2 & Trial 3 & 297.7/1442.6 & 0543 & $4 / 25 / 2013$ & $6 / 14 / 2013$ & 218.5 & 55 & $6 / 19 / 2013$ & 261.5 & $\mathrm{HCN}$ \\
\hline 2 & Trial 3 & 297.7/1442.6 & 0589 & $4 / 25 / 2013$ & $6 / 14 / 2013$ & 228.6 & 55 & $6 / 19 / 2013$ & 273.1 & $\mathrm{HCN}$ \\
\hline 2 & Trial 3 & 297.7/1442.6 & 0591 & $4 / 25 / 2013$ & $6 / 14 / 2013$ & 227.5 & 55 & $6 / 19 / 2013$ & 274.9 & $\mathrm{HCN}$ \\
\hline 2 & Trial 3 & 297.7/1442.6 & 0593 & $4 / 25 / 2013$ & $6 / 14 / 2013$ & 227.7 & 55 & $6 / 19 / 2013$ & 273.5 & $\mathrm{HCN}$ \\
\hline 2 & Trial 3 & 297.7/1442.6 & 0595 & $4 / 25 / 2013$ & $6 / 14 / 2013$ & 233.7 & 55 & $6 / 19 / 2013$ & 275.6 & Euthanasia \\
\hline 2 & Trial 3 & 297.7/1442.6 & 0621 & $4 / 25 / 2013$ & $6 / 14 / 2013$ & 235.2 & 55 & $6 / 19 / 2013$ & 278.0 & $\mathrm{HCN}$ \\
\hline 2 & Trial 3 & 297.7/1442.6 & 0623 & $4 / 25 / 2013$ & $6 / 14 / 2013$ & 224.3 & 55 & $6 / 19 / 2013$ & 272.3 & Euthanasia \\
\hline 2 & Trial 3 & 297.7/1442.6 & 0657 & $4 / 25 / 2013$ & $6 / 14 / 2013$ & 230.0 & 55 & $6 / 19 / 2013$ & 278.4 & $\mathrm{HCN}$ \\
\hline 2 & Trial 3 & 297.7/1442.6 & 0659 & $4 / 25 / 2013$ & $6 / 14 / 2013$ & 230.5 & 55 & $6 / 19 / 2013$ & 278.9 & Euthanasia \\
\hline 2 & Trial 4 & 265.5/1299.4 & 0677 & $5 / 2 / 2013$ & $6 / 21 / 2013$ & 227.2 & 53 & $6 / 24 / 2013$ & 248.1 & Euthanasia \\
\hline 2 & Trial 4 & 265.5/1299.4 & 0679 & $5 / 2 / 2013$ & $6 / 21 / 2013$ & 255.2 & 53 & $6 / 24 / 2013$ & 288.7 & Euthanasia \\
\hline 2 & Trial 4 & 265.5/1299.4 & 0681 & $5 / 2 / 2013$ & $6 / 21 / 2013$ & 244.7 & 53 & $6 / 24 / 2013$ & 280.5 & $\mathrm{HCN}$ \\
\hline
\end{tabular}




\begin{tabular}{|c|c|c|c|c|c|c|c|c|c|c|}
\hline $\begin{array}{l}\text { Profile } \\
(1-11)\end{array}$ & $\begin{array}{c}\text { Trial } \\
\text { Number }\end{array}$ & $\begin{array}{c}\text { Concentration } \\
\text { (ppm) }\end{array}$ & $\begin{array}{c}\text { Animal } \\
\#\end{array}$ & $\begin{array}{c}\text { Date of } \\
\text { Birth }\end{array}$ & $\begin{array}{c}\text { Date } \\
\text { Weighed }\end{array}$ & $\begin{array}{c}\text { Random- } \\
\text { ization } \\
\text { Weight }(\mathrm{g})\end{array}$ & $\begin{array}{c}\text { Age at } \\
\text { Exposure } \\
\text { (days) }\end{array}$ & $\begin{array}{c}\text { Date of } \\
\text { Exposure }\end{array}$ & $\begin{array}{c}\text { Weight at } \\
\text { Exposure } \\
\text { (g) }\end{array}$ & Mode of Death \\
\hline 2 & Trial 4 & $265.5 / 1299.4$ & 0683 & $5 / 2 / 2013$ & $6 / 21 / 2013$ & 241.3 & 53 & $6 / 24 / 2013$ & 271.9 & Euthanasia \\
\hline 2 & Trial 4 & $265.5 / 1299.4$ & 0697 & $5 / 2 / 2013$ & $6 / 21 / 2013$ & 240.5 & 53 & $6 / 24 / 2013$ & 263.8 & $\mathrm{HCN}$ \\
\hline 2 & Trial 4 & $265.5 / 1299.4$ & 0699 & $5 / 2 / 2013$ & $6 / 21 / 2013$ & 261.4 & 53 & $6 / 24 / 2013$ & 297.0 & Euthanasia \\
\hline 2 & Trial 4 & $265.5 / 1299.4$ & 0801 & $5 / 2 / 2013$ & $6 / 21 / 2013$ & 247.5 & 53 & $6 / 24 / 2013$ & 270.3 & Euthanasia \\
\hline 2 & Trial 4 & $265.5 / 1299.4$ & 0803 & $5 / 2 / 2013$ & $6 / 21 / 2013$ & 236.0 & 53 & $6 / 24 / 2013$ & 265.7 & $\mathrm{HCN}$ \\
\hline 2 & Trial 4 & $265.5 / 1299.4$ & 0861 & $5 / 2 / 2013$ & $6 / 21 / 2013$ & 264.8 & 53 & $6 / 24 / 2013$ & 297.3 & $\mathrm{HCN}$ \\
\hline 2 & Trial 4 & $265.5 / 1299.4$ & 0863 & $5 / 2 / 2013$ & $6 / 21 / 2013$ & 229.4 & 53 & $6 / 24 / 2013$ & 254.5 & $\mathrm{HCN}$ \\
\hline 3 & Trial 1 & $261.7 / 1157.6$ & 0065 & $4 / 11 / 2013$ & $5 / 31 / 2013$ & 209.7 & 55 & $6 / 5 / 2013$ & 234.2 & Euthanasia \\
\hline 3 & Trial 1 & $261.7 / 1157.6$ & 0067 & $4 / 11 / 2013$ & $5 / 31 / 2013$ & 218.3 & 55 & $6 / 5 / 2013$ & 238.1 & $\mathrm{HCN}$ \\
\hline 3 & Trial 1 & $261.7 / 1157.6$ & 0089 & $4 / 11 / 2013$ & $5 / 31 / 2013$ & 205.3 & 55 & $6 / 5 / 2013$ & 263.4 & Euthanasia \\
\hline 3 & Trial 1 & $261.7 / 1157.6$ & 0091 & 4/11/2013 & $5 / 31 / 2013$ & 202.5 & 55 & $6 / 5 / 2013$ & 250.2 & $\mathrm{HCN}$ \\
\hline 3 & Trial 1 & $261.7 / 1157.6$ & 0141 & $4 / 11 / 2013$ & $5 / 31 / 2013$ & 217.9 & 55 & $6 / 5 / 2013$ & 263.7 & Euthanasia \\
\hline 3 & Trial 1 & $261.7 / 1157.6$ & 0143 & $4 / 11 / 2013$ & $5 / 31 / 2013$ & 207.2 & 55 & $6 / 5 / 2013$ & 250.7 & $\mathrm{HCN}$ \\
\hline 3 & Trial 1 & $261.7 / 1157.6$ & 0145 & $4 / 11 / 2013$ & $5 / 31 / 2013$ & 208.1 & 55 & $6 / 5 / 2013$ & 255.5 & $\mathrm{HCN}$ \\
\hline 3 & Trial 1 & $261.7 / 1157.6$ & 0147 & $4 / 11 / 2013$ & $5 / 31 / 2013$ & 223.9 & 55 & $6 / 5 / 2013$ & 267.5 & $\mathrm{HCN}$ \\
\hline 3 & Trial 1 & $261.7 / 1157.6$ & 0213 & $4 / 11 / 2013$ & $5 / 31 / 2013$ & 196.4 & 55 & $6 / 5 / 2013$ & 239.0 & Euthanasia \\
\hline 3 & Trial 1 & $261.7 / 1157.6$ & 0215 & $4 / 11 / 2013$ & $5 / 31 / 2013$ & 222.9 & 55 & $6 / 5 / 2013$ & 268.7 & $\mathrm{HCN}$ \\
\hline 3 & Trial 2 & $183.4 / 899.9$ & 0289 & $4 / 18 / 2013$ & $6 / 7 / 2013$ & 251.8 & 54 & $6 / 11 / 2013$ & 292.3 & Euthanasia \\
\hline 3 & Trial 2 & $183.4 / 899.9$ & 0291 & 4/18/2013 & 6/7/2013 & 207.6 & 54 & $6 / 11 / 2013$ & 243.4 & Euthanasia \\
\hline 3 & Trial 2 & $183.4 / 899.9$ & 0325 & 4/18/2013 & 6/7/2013 & 213.8 & 54 & $6 / 11 / 2013$ & 245.0 & Euthanasia \\
\hline 3 & Trial 2 & $183.4 / 899.9$ & 0327 & $4 / 18 / 2013$ & $6 / 7 / 2013$ & 241.0 & 54 & $6 / 11 / 2013$ & 274.7 & Euthanasia \\
\hline 3 & Trial 2 & $183.4 / 899.9$ & 0361 & $4 / 18 / 2013$ & $6 / 7 / 2013$ & 230.9 & 54 & $6 / 11 / 2013$ & 261.5 & Euthanasia \\
\hline 3 & Trial 2 & $183.4 / 899.9$ & 0363 & $4 / 18 / 2013$ & 6/7/2013 & 215.4 & 54 & $6 / 11 / 2013$ & 245.6 & Euthanasia \\
\hline 3 & Trial 2 & $183.4 / 899.9$ & 0369 & $4 / 18 / 2013$ & $6 / 7 / 2013$ & 251.8 & 54 & $6 / 11 / 2013$ & 285.5 & $\mathrm{HCN}$ \\
\hline 3 & Trial 2 & $183.4 / 899.9$ & 0371 & $4 / 18 / 2013$ & $6 / 7 / 2013$ & 198.1 & 54 & $6 / 11 / 2013$ & 220.6 & Euthanasia \\
\hline 3 & Trial 2 & $183.4 / 899.9$ & 0433 & $4 / 18 / 2013$ & $6 / 7 / 2013$ & 224.6 & 54 & $6 / 11 / 2013$ & 265.0 & $\mathrm{HCN}$ \\
\hline 3 & Trial 2 & $183.4 / 899.9$ & 0435 & $4 / 18 / 2013$ & 6/7/2013 & 242.9 & 54 & $6 / 11 / 2013$ & 279.0 & $\mathrm{HCN}$ \\
\hline 3 & Trial 3 & $270.8 / 1331.8$ & 0573 & $4 / 25 / 2013$ & $6 / 14 / 2013$ & 247.5 & 55 & 6/19/2013 & 283.8 & $\mathrm{HCN}$ \\
\hline
\end{tabular}




\begin{tabular}{|c|c|c|c|c|c|c|c|c|c|c|}
\hline $\begin{array}{l}\text { Profile } \\
(1-11)\end{array}$ & $\begin{array}{c}\text { Trial } \\
\text { Number }\end{array}$ & $\begin{array}{c}\text { Concentration } \\
(\mathrm{ppm})\end{array}$ & $\begin{array}{c}\text { Animal } \\
\#\end{array}$ & $\begin{array}{l}\text { Date of } \\
\text { Birth }\end{array}$ & $\begin{array}{c}\text { Date } \\
\text { Weighed }\end{array}$ & $\begin{array}{c}\text { Random- } \\
\text { ization } \\
\text { Weight (g) }\end{array}$ & $\begin{array}{c}\text { Age at } \\
\text { Exposure } \\
\text { (days) }\end{array}$ & $\begin{array}{c}\text { Date of } \\
\text { Exposure }\end{array}$ & $\begin{array}{c}\text { Weight at } \\
\text { Exposure } \\
\text { (g) }\end{array}$ & Mode of Death \\
\hline 3 & Trial 3 & $270.8 / 1331.8$ & 0575 & $4 / 25 / 2013$ & $6 / 14 / 2013$ & 211.8 & 55 & $6 / 19 / 2013$ & 255.3 & $\mathrm{HCN}$ \\
\hline 3 & Trial 3 & 270.8/1331.8 & 0581 & $4 / 25 / 2013$ & $6 / 14 / 2013$ & 223.3 & 55 & $6 / 19 / 2013$ & 269.4 & $\mathrm{HCN}$ \\
\hline 3 & Trial 3 & $270.8 / 1331.8$ & 0583 & $4 / 25 / 2013$ & $6 / 14 / 2013$ & 237.0 & 55 & $6 / 19 / 2013$ & 284.7 & $\mathrm{HCN}$ \\
\hline 3 & Trial 3 & 270.8/1331.8 & 0613 & $4 / 25 / 2013$ & $6 / 14 / 2013$ & 242.1 & 55 & $6 / 19 / 2013$ & 275.9 & $\mathrm{HCN}$ \\
\hline 3 & Trial 3 & 270.8/1331.8 & 0615 & $4 / 25 / 2013$ & $6 / 14 / 2013$ & 219.3 & 55 & $6 / 19 / 2013$ & 247.0 & $\mathrm{HCN}$ \\
\hline 3 & Trial 3 & 270.8/1331.8 & 0629 & $4 / 25 / 2013$ & $6 / 14 / 2013$ & 228.4 & 55 & $6 / 19 / 2013$ & 270.3 & $\mathrm{HCN}$ \\
\hline 3 & Trial 3 & 270.8/1331.8 & 0631 & $4 / 25 / 2013$ & $6 / 14 / 2013$ & 224.6 & 55 & $6 / 19 / 2013$ & 261.7 & $\mathrm{HCN}$ \\
\hline 3 & Trial 3 & 270.8/1331.8 & 0645 & $4 / 25 / 2013$ & $6 / 14 / 2013$ & 226.0 & 55 & $6 / 19 / 2013$ & 269.5 & $\mathrm{HCN}$ \\
\hline 3 & Trial 3 & 270.8/1331.8 & 0647 & $4 / 25 / 2013$ & $6 / 14 / 2013$ & 229.2 & 55 & $6 / 19 / 2013$ & 272.5 & $\mathrm{HCN}$ \\
\hline 3 & Trial 4 & 205.1/1014.4 & 0661 & $5 / 2 / 2013$ & $6 / 21 / 2013$ & 224.9 & 55 & $6 / 26 / 2013$ & 265.9 & Euthanasia \\
\hline 3 & Trial 4 & 205.1/1014.4 & 0663 & $5 / 2 / 2013$ & $6 / 21 / 2013$ & 237.1 & 55 & $6 / 26 / 2013$ & 280.7 & $\mathrm{HCN}$ \\
\hline 3 & Trial 4 & 205.1/1014.4 & 0717 & $5 / 2 / 2013$ & $6 / 21 / 2013$ & 220.4 & 55 & $6 / 26 / 2013$ & 262.7 & Euthanasia \\
\hline 3 & Trial 4 & 205.1/1014.4 & 0719 & $5 / 2 / 2013$ & $6 / 21 / 2013$ & 242.8 & 55 & $6 / 26 / 2013$ & 290.3 & Euthanasia \\
\hline 3 & Trial 4 & 205.1/1014.4 & 0729 & $5 / 2 / 2013$ & $6 / 21 / 2013$ & 242.9 & 55 & $6 / 26 / 2013$ & 288.2 & $\mathrm{HCN}$ \\
\hline 3 & Trial 4 & $205.1 / 1014.4$ & 0731 & $5 / 2 / 2013$ & $6 / 21 / 2013$ & 223.4 & 55 & $6 / 26 / 2013$ & 266.2 & $\mathrm{HCN}$ \\
\hline 3 & Trial 4 & 205.1/1014.4 & 0737 & $5 / 2 / 2013$ & $6 / 21 / 2013$ & 244.2 & 55 & $6 / 26 / 2013$ & 287.9 & Euthanasia \\
\hline 3 & Trial 4 & 205.1/1014.4 & 0739 & $5 / 2 / 2013$ & $6 / 21 / 2013$ & 224.1 & 55 & $6 / 26 / 2013$ & 264.2 & $\mathrm{HCN}$ \\
\hline 3 & Trial 4 & 205.1/1014.4 & 0809 & $5 / 2 / 2013$ & $6 / 21 / 2013$ & 230.3 & 55 & $6 / 26 / 2013$ & 274.4 & $\mathrm{HCN}$ \\
\hline 3 & Trial 4 & 205.1/1014.4 & 0811 & $5 / 2 / 2013$ & $6 / 21 / 2013$ & 240.0 & 55 & $6 / 26 / 2013$ & 288.3 & $\mathrm{HCN}$ \\
\hline 4 & Trial 1 & $444.9 / 2178.1$ & 0057 & $4 / 11 / 2013$ & $5 / 31 / 2013$ & 204.0 & 56 & $6 / 6 / 2013$ & 251.8 & $\mathrm{HCN}$ \\
\hline 4 & Trial 1 & $444.9 / 2178.1$ & 0059 & $4 / 11 / 2013$ & $5 / 31 / 2013$ & 176.5 & 56 & 6/6/2013 & 223.5 & $\mathrm{HCN}$ \\
\hline 4 & Trial 1 & $444.9 / 2178.1$ & 0109 & $4 / 11 / 2013$ & $5 / 31 / 2013$ & 175.8 & 56 & 6/6/2013 & 225.2 & $\mathrm{HCN}$ \\
\hline 4 & Trial 1 & $444.9 / 2178.1$ & 0111 & $4 / 11 / 2013$ & $5 / 31 / 2013$ & 218.8 & 56 & 6/6/2013 & 274.9 & Euthanasia \\
\hline 4 & Trial 1 & $444.9 / 2178.1$ & 0125 & $4 / 11 / 2013$ & $5 / 31 / 2013$ & 192.1 & 56 & 6/6/2013 & 239.5 & Euthanasia \\
\hline 4 & Trial 1 & $444.9 / 2178.1$ & 0127 & $4 / 11 / 2013$ & $5 / 31 / 2013$ & 194.0 & 56 & 6/6/2013 & 248.7 & Euthanasia \\
\hline 4 & Trial 1 & $444.9 / 2178.1$ & 0129 & $4 / 11 / 2013$ & $5 / 31 / 2013$ & 181.5 & 56 & 6/6/2013 & 244.5 & Euthanasia \\
\hline 4 & Trial 1 & $444.9 / 2178.1$ & 0131 & $4 / 11 / 2013$ & $5 / 31 / 2013$ & 163.2 & 56 & 6/6/2013 & 232.7 & Euthanasia \\
\hline 4 & Trial 1 & $444.9 / 2178.1$ & 0177 & $4 / 11 / 2013$ & $5 / 31 / 2013$ & 189.8 & 56 & 6/6/2013 & 239.8 & Euthanasia \\
\hline
\end{tabular}




\begin{tabular}{|c|c|c|c|c|c|c|c|c|c|c|}
\hline $\begin{array}{l}\text { Profile } \\
(1-11)\end{array}$ & $\begin{array}{c}\text { Trial } \\
\text { Number }\end{array}$ & $\begin{array}{l}\text { Concentration } \\
(\mathrm{ppm})\end{array}$ & $\begin{array}{c}\text { Animal } \\
\#\end{array}$ & $\begin{array}{l}\text { Date of } \\
\text { Birth }\end{array}$ & $\begin{array}{c}\text { Date } \\
\text { Weighed }\end{array}$ & $\begin{array}{l}\text { Random- } \\
\text { ization } \\
\text { Weight }(\mathrm{g})\end{array}$ & $\begin{array}{c}\text { Age at } \\
\text { Exposure } \\
\text { (days) }\end{array}$ & $\begin{array}{c}\text { Date of } \\
\text { Exposure }\end{array}$ & $\begin{array}{l}\text { Weight at } \\
\text { Exposure } \\
(\mathrm{g})\end{array}$ & Mode of Death \\
\hline 4 & Trial 1 & $444.9 / 2178.1$ & 0179 & $4 / 11 / 2013$ & $5 / 31 / 2013$ & 208.0 & 56 & $6 / 6 / 2013$ & 256.0 & Euthanasia \\
\hline 4 & Trial 2 & $566.5 / 2793.3$ & 0285 & $4 / 18 / 2013$ & 6/7/2013 & 216.6 & 55 & $6 / 12 / 2013$ & 257.7 & $\mathrm{HCN}$ \\
\hline 4 & Trial 2 & $566.5 / 2793.3$ & 0287 & $4 / 18 / 2013$ & $6 / 7 / 2013$ & 222.4 & 55 & $6 / 12 / 2013$ & 258.5 & $\mathrm{HCN}$ \\
\hline 4 & Trial 2 & $566.5 / 2793.3$ & 0301 & $4 / 18 / 2013$ & 6/7/2013 & 224.4 & 55 & $6 / 12 / 2013$ & 263.1 & $\mathrm{HCN}$ \\
\hline 4 & Trial 2 & $566.5 / 2793.3$ & 0303 & $4 / 18 / 2013$ & 6/7/2013 & 209.6 & 55 & $6 / 12 / 2013$ & 238.8 & $\mathrm{HCN}$ \\
\hline 4 & Trial 2 & $566.5 / 2793.3$ & 0321 & $4 / 18 / 2013$ & 6/7/2013 & 233.9 & 55 & $6 / 12 / 2013$ & 277.0 & $\mathrm{HCN}$ \\
\hline 4 & Trial 2 & $566.5 / 2793.3$ & 0323 & $4 / 18 / 2013$ & 6/7/2013 & 194.8 & 55 & $6 / 12 / 2013$ & 223.1 & $\mathrm{HCN}$ \\
\hline 4 & Trial 2 & $566.5 / 2793.3$ & 0373 & $4 / 18 / 2013$ & 6/7/2013 & 218.7 & 55 & $6 / 12 / 2013$ & 267.8 & $\mathrm{HCN}$ \\
\hline 4 & Trial 2 & $566.5 / 2793.3$ & 0375 & $4 / 18 / 2013$ & 6/7/2013 & 224.6 & 55 & $6 / 12 / 2013$ & 272.6 & $\mathrm{HCN}$ \\
\hline 4 & Trial 2 & $566.5 / 2793.3$ & 0413 & $4 / 18 / 2013$ & 6/7/2013 & 209.7 & 55 & $6 / 12 / 2013$ & 245.8 & $\mathrm{HCN}$ \\
\hline 4 & Trial 2 & $566.5 / 2793.3$ & 0415 & $4 / 18 / 2013$ & 6/7/2013 & 235.1 & 55 & $6 / 12 / 2013$ & 285.1 & $\mathrm{HCN}$ \\
\hline 4 & Trial 3 & $501.0 / 2474.9$ & 0501 & $4 / 25 / 2013$ & $6 / 14 / 2013$ & 221.6 & 54 & $6 / 18 / 2013$ & 261.1 & Euthanasia \\
\hline 4 & Trial 3 & $501.0 / 2474.9$ & 0503 & $4 / 25 / 2013$ & $6 / 14 / 2013$ & 243.6 & 54 & $6 / 18 / 2013$ & 287.3 & $\mathrm{HCN}$ \\
\hline 4 & Trial 3 & $501.0 / 2474.9$ & 0505 & $4 / 25 / 2013$ & $6 / 14 / 2013$ & 225.4 & 54 & $6 / 18 / 2013$ & 262.0 & $\mathrm{HCN}$ \\
\hline 4 & Trial 3 & $501.0 / 2474.9$ & 0507 & $4 / 25 / 2013$ & $6 / 14 / 2013$ & 241.0 & 54 & $6 / 18 / 2013$ & 280.9 & Euthanasia \\
\hline 4 & Trial 3 & $501.0 / 2474.9$ & 0533 & $4 / 25 / 2013$ & $6 / 14 / 2013$ & 222.8 & 54 & $6 / 18 / 2013$ & 258.2 & Euthanasia \\
\hline 4 & Trial 3 & $501.0 / 2474.9$ & 0535 & $4 / 25 / 2013$ & $6 / 14 / 2013$ & 244.5 & 54 & $6 / 18 / 2013$ & 282.6 & $\mathrm{HCN}$ \\
\hline 4 & Trial 3 & $501.0 / 2474.9$ & 0557 & $4 / 25 / 2013$ & $6 / 14 / 2013$ & 214.0 & 54 & $6 / 18 / 2013$ & 248.5 & $\mathrm{HCN}$ \\
\hline 4 & Trial 3 & $501.0 / 2474.9$ & 0559 & $4 / 25 / 2013$ & $6 / 14 / 2013$ & 254.7 & 54 & $6 / 18 / 2013$ & 294.4 & $\mathrm{HCN}$ \\
\hline 4 & Trial 3 & $501.0 / 2474.9$ & 0577 & $4 / 25 / 2013$ & $6 / 14 / 2013$ & 247.3 & 54 & $6 / 18 / 2013$ & 284.3 & $\mathrm{HCN}$ \\
\hline 4 & Trial 3 & $501.0 / 2474.9$ & 0579 & $4 / 25 / 2013$ & $6 / 14 / 2013$ & 215.7 & 54 & $6 / 18 / 2013$ & 256.9 & $\mathrm{HCN}$ \\
\hline 4 & Trial 4 & $471.8 / 2331.5$ & 0689 & $5 / 2 / 2013$ & $6 / 21 / 2013$ & 242.6 & 53 & $6 / 24 / 2013$ & 267.1 & $\mathrm{HCN}$ \\
\hline 4 & Trial 4 & $471.8 / 2331.5$ & 0691 & $5 / 2 / 2013$ & $6 / 21 / 2013$ & 239.2 & 53 & $6 / 24 / 2013$ & 259.8 & $\mathrm{HCN}$ \\
\hline 4 & Trial 4 & $471.8 / 2331.5$ & 0733 & $5 / 2 / 2013$ & $6 / 21 / 2013$ & 242.1 & 53 & $6 / 24 / 2013$ & 272.7 & $\mathrm{HCN}$ \\
\hline 4 & Trial 4 & $471.8 / 2331.5$ & 0735 & $5 / 2 / 2013$ & $6 / 21 / 2013$ & 257.6 & 53 & $6 / 24 / 2013$ & 284.9 & $\mathrm{HCN}$ \\
\hline 4 & Trial 4 & $471.8 / 2331.5$ & 0769 & $5 / 2 / 2013$ & $6 / 21 / 2013$ & 251.4 & 53 & $6 / 24 / 2013$ & 280.7 & $\mathrm{HCN}$ \\
\hline 4 & Trial 4 & $471.8 / 2331.5$ & 0771 & $5 / 2 / 2013$ & $6 / 21 / 2013$ & 242.5 & 53 & $6 / 24 / 2013$ & 237.1 & $\mathrm{HCN}$ \\
\hline 4 & Trial 4 & $471.8 / 2331.5$ & 0793 & $5 / 2 / 2013$ & $6 / 21 / 2013$ & 246.4 & 53 & $6 / 24 / 2013$ & 262.7 & $\mathrm{HCN}$ \\
\hline
\end{tabular}




\begin{tabular}{|c|c|c|c|c|c|c|c|c|c|c|}
\hline $\begin{array}{l}\text { Profile } \\
(1-11)\end{array}$ & $\begin{array}{c}\text { Trial } \\
\text { Number }\end{array}$ & $\begin{array}{c}\text { Concentration } \\
(\mathrm{ppm})\end{array}$ & $\begin{array}{c}\text { Animal } \\
\#\end{array}$ & $\begin{array}{l}\text { Date of } \\
\text { Birth }\end{array}$ & $\begin{array}{c}\text { Date } \\
\text { Weighed }\end{array}$ & $\begin{array}{c}\text { Random- } \\
\text { ization } \\
\text { Weight (g) }\end{array}$ & $\begin{array}{c}\text { Age at } \\
\text { Exposure } \\
\text { (days) }\end{array}$ & $\begin{array}{c}\text { Date of } \\
\text { Exposure }\end{array}$ & $\begin{array}{c}\text { Weight at } \\
\text { Exposure } \\
\text { (g) }\end{array}$ & Mode of Death \\
\hline 4 & Trial 4 & $471.8 / 2331.5$ & 0795 & $5 / 2 / 2013$ & $6 / 21 / 2013$ & 238.1 & 53 & $6 / 24 / 2013$ & 261.7 & $\mathrm{HCN}$ \\
\hline 4 & Trial 4 & $471.8 / 2331.5$ & 0829 & $5 / 2 / 2013$ & $6 / 21 / 2013$ & 245.9 & 53 & $6 / 24 / 2013$ & 274.1 & $\mathrm{HCN}$ \\
\hline 4 & Trial 4 & $471.8 / 2331.5$ & 0831 & $5 / 2 / 2013$ & $6 / 21 / 2013$ & 236.9 & 53 & $6 / 24 / 2013$ & 260.7 & $\mathrm{HCN}$ \\
\hline 4 & Trial 5 & $442.0 / 2177.5$ & 0909 & $5 / 9 / 2013$ & $6 / 28 / 2013$ & 219.3 & 53 & $7 / 1 / 2013$ & 243.1 & $\mathrm{HCN}$ \\
\hline 4 & Trial 5 & $442.0 / 2177.5$ & 0911 & $5 / 9 / 2013$ & $6 / 28 / 2013$ & 219.4 & 53 & 7/1/2013 & 241.9 & $\mathrm{HCN}$ \\
\hline 4 & Trial 5 & $442.0 / 2177.5$ & 0949 & $5 / 9 / 2013$ & $6 / 28 / 2013$ & 222.4 & 53 & 7/1/2013 & 248.8 & $\mathrm{HCN}$ \\
\hline 4 & Trial 5 & $442.0 / 2177.5$ & 0951 & $5 / 9 / 2013$ & $6 / 28 / 2013$ & 244.3 & 53 & $7 / 1 / 2013$ & 268.9 & $\mathrm{HCN}$ \\
\hline 4 & Trial 5 & $442.0 / 2177.5$ & 0957 & $5 / 9 / 2013$ & $6 / 28 / 2013$ & 228.3 & 53 & $7 / 1 / 2013$ & 251.7 & $\mathrm{HCN}$ \\
\hline 4 & Trial 5 & $442.0 / 2177.5$ & 0959 & $5 / 9 / 2013$ & $6 / 28 / 2013$ & 227.7 & 53 & $7 / 1 / 2013$ & 253.7 & $\mathrm{HCN}$ \\
\hline 4 & Trial 5 & $442.0 / 2177.5$ & 0969 & $5 / 9 / 2013$ & $6 / 28 / 2013$ & 261.2 & 53 & 7/1/2013 & 293.7 & $\mathrm{HCN}$ \\
\hline 4 & Trial 5 & $442.0 / 2177.5$ & 0971 & $5 / 9 / 2013$ & $6 / 28 / 2013$ & 226.3 & 53 & $7 / 1 / 2013$ & 254.7 & $\mathrm{HCN}$ \\
\hline 4 & Trial 5 & $442.0 / 2177.5$ & 0973 & $5 / 9 / 2013$ & $6 / 28 / 2013$ & 240.4 & 53 & $7 / 1 / 2013$ & 268.9 & $\mathrm{HCN}$ \\
\hline 4 & Trial 5 & $442.0 / 2177.5$ & 0975 & $5 / 9 / 2013$ & $6 / 28 / 2013$ & 206.8 & 53 & $7 / 1 / 2013$ & 234.7 & $\mathrm{HCN}$ \\
\hline 4 & Trial 6 & $376.6 / 1847.7$ & 1005 & $6 / 6 / 2013$ & $7 / 26 / 2013$ & 221.8 & 53 & $7 / 29 / 2013$ & 253.1 & Euthanasia \\
\hline 4 & Trial 6 & $376.6 / 1847.7$ & 1007 & 6/6/2013 & $7 / 26 / 2013$ & 231.0 & 53 & $7 / 29 / 2013$ & 254.5 & Euthanasia \\
\hline 4 & Trial 6 & $376.6 / 1847.7$ & 1033 & 6/6/2013 & $7 / 26 / 2013$ & 232.1 & 53 & $7 / 29 / 2013$ & 258.8 & $\mathrm{HCN}$ \\
\hline 4 & Trial 6 & $376.6 / 1847.7$ & 1035 & $6 / 6 / 2013$ & $7 / 26 / 2013$ & 211.9 & 53 & $7 / 29 / 2013$ & 235.2 & $\mathrm{HCN}$ \\
\hline 4 & Trial 6 & $376.6 / 1847.7$ & 1037 & 6/6/2013 & $7 / 26 / 2013$ & 224.6 & 53 & $7 / 29 / 2013$ & 254.0 & Euthanasia \\
\hline 4 & Trial 6 & $376.6 / 1847.7$ & 1039 & 6/6/2013 & $7 / 26 / 2013$ & 237.1 & 53 & $7 / 29 / 2013$ & 268.3 & $\mathrm{HCN}$ \\
\hline 4 & Trial 6 & $376.6 / 1847.7$ & 1045 & 6/6/2013 & $7 / 26 / 2013$ & 216.1 & 53 & $7 / 29 / 2013$ & 247.2 & $\mathrm{HCN}$ \\
\hline 4 & Trial 6 & $376.6 / 1847.7$ & 1047 & 6/6/2013 & $7 / 26 / 2013$ & 232.7 & 53 & $7 / 29 / 2013$ & 258.8 & $\mathrm{HCN}$ \\
\hline 4 & Trial 6 & $376.6 / 1847.7$ & 1057 & $6 / 6 / 2013$ & $7 / 26 / 2013$ & 227.0 & 53 & $7 / 29 / 2013$ & 250.4 & Euthanasia \\
\hline 4 & Trial 6 & $376.6 / 1847.7$ & 1059 & 6/6/2013 & $7 / 26 / 2013$ & 219.8 & 53 & 7/29/2013 & 242.5 & Euthanasia \\
\hline 4 & Trial 7 & $322.7 / 1573.6$ & 1025 & 6/6/2013 & $7 / 26 / 2013$ & 199.8 & 55 & $7 / 31 / 2013$ & 240.5 & Euthanasia \\
\hline 4 & Trial 7 & $322.7 / 1573.6$ & 1027 & 6/6/2013 & $7 / 26 / 2013$ & 213.3 & 55 & $7 / 31 / 2013$ & 262.7 & Euthanasia \\
\hline 4 & Trial 7 & $322.7 / 1573.6$ & 1029 & 6/6/2013 & $7 / 26 / 2013$ & 187.2 & 55 & $7 / 31 / 2013$ & 222.2 & $\mathrm{HCN}$ \\
\hline 4 & Trial 7 & $322.7 / 1573.6$ & 1031 & $6 / 6 / 2013$ & $7 / 26 / 2013$ & 209.3 & 55 & $7 / 31 / 2013$ & 257.0 & $\mathrm{HCN}$ \\
\hline 4 & Trial 7 & $322.7 / 1573.6$ & 1041 & $6 / 6 / 2013$ & $7 / 26 / 2013$ & 210.2 & 55 & $7 / 31 / 2013$ & 259.9 & Euthanasia \\
\hline
\end{tabular}




\begin{tabular}{|c|c|c|c|c|c|c|c|c|c|c|}
\hline $\begin{array}{l}\text { Profile } \\
(1-11)\end{array}$ & $\begin{array}{c}\text { Trial } \\
\text { Number }\end{array}$ & $\begin{array}{c}\text { Concentration } \\
(\mathrm{ppm})\end{array}$ & $\begin{array}{c}\text { Animal } \\
\#\end{array}$ & $\begin{array}{l}\text { Date of } \\
\text { Birth }\end{array}$ & $\begin{array}{c}\text { Date } \\
\text { Weighed }\end{array}$ & $\begin{array}{c}\text { Random- } \\
\text { ization } \\
\text { Weight (g) }\end{array}$ & $\begin{array}{c}\text { Age at } \\
\text { Exposure } \\
\text { (days) }\end{array}$ & $\begin{array}{c}\text { Date of } \\
\text { Exposure }\end{array}$ & $\begin{array}{c}\text { Weight at } \\
\text { Exposure } \\
\text { (g) }\end{array}$ & Mode of Death \\
\hline 4 & Trial 7 & $322.7 / 1573.6$ & 1043 & $6 / 6 / 2013$ & $7 / 26 / 2013$ & 208.2 & 55 & $7 / 31 / 2013$ & 259.8 & Euthanasia \\
\hline 4 & Trial 7 & $322.7 / 1573.6$ & 1073 & $6 / 6 / 2013$ & $7 / 26 / 2013$ & 200.8 & 55 & $7 / 31 / 2013$ & 251.5 & Euthanasia \\
\hline 4 & Trial 7 & $322.7 / 1573.6$ & 1075 & $6 / 6 / 2013$ & $7 / 26 / 2013$ & 206.4 & 55 & $7 / 31 / 2013$ & 248.1 & Euthanasia \\
\hline 4 & Trial 7 & $322.7 / 1573.6$ & 1097 & $6 / 6 / 2013$ & $7 / 26 / 2013$ & 229.3 & 55 & $7 / 31 / 2013$ & 270.8 & Euthanasia \\
\hline 4 & Trial 7 & $322.7 / 1573.6$ & 1099 & $6 / 6 / 2013$ & $7 / 26 / 2013$ & 180.5 & 55 & $7 / 31 / 2013$ & 211.8 & $\mathrm{HCN}$ \\
\hline 4 & Trial 8 & 277.8/1368.6 & 1125 & $7 / 4 / 2013$ & $8 / 23 / 2013$ & 212.1 & 54 & $8 / 27 / 2013$ & 236.5 & $\mathrm{HCN}$ \\
\hline 4 & Trial 8 & 277.8/1368.6 & 1127 & $7 / 4 / 2013$ & $8 / 23 / 2013$ & 249.4 & 54 & $8 / 27 / 2013$ & 282.8 & $\mathrm{HCN}$ \\
\hline 4 & Trial 8 & 277.8/1368.6 & 1129 & $7 / 4 / 2013$ & $8 / 23 / 2013$ & 236.0 & 54 & $8 / 27 / 2013$ & 278.2 & Euthanasia \\
\hline 4 & Trial 8 & 277.8/1368.6 & 1131 & $7 / 4 / 2013$ & $8 / 23 / 2013$ & 228.8 & 54 & $8 / 27 / 2013$ & 259.8 & $\mathrm{HCN}$ \\
\hline 4 & Trial 8 & 277.8/1368.6 & 1141 & $7 / 4 / 2013$ & $8 / 23 / 2013$ & 217.5 & 54 & $8 / 27 / 2013$ & 246.0 & Euthanasia \\
\hline 4 & Trial 8 & 277.8/1368.6 & 1143 & $7 / 4 / 2013$ & $8 / 23 / 2013$ & 239.8 & 54 & $8 / 27 / 2013$ & 275.4 & Euthanasia \\
\hline 4 & Trial 8 & 277.8/1368.6 & 1149 & $7 / 4 / 2013$ & $8 / 23 / 2013$ & 224.7 & 54 & $8 / 27 / 2013$ & 255.8 & $\mathrm{HCN}$ \\
\hline 4 & Trial 8 & 277.8/1368.6 & 1151 & $7 / 4 / 2013$ & $8 / 23 / 2013$ & 240.2 & 54 & $8 / 27 / 2013$ & 277.4 & Euthanasia \\
\hline 4 & Trial 8 & 277.8/1368.6 & 1193 & $7 / 4 / 2013$ & $8 / 23 / 2013$ & 250.7 & 54 & $8 / 27 / 2013$ & 287.5 & $\mathrm{HCN}$ \\
\hline 4 & Trial 8 & 277.8/1368.6 & 1195 & $7 / 4 / 2013$ & $8 / 23 / 2013$ & 220.7 & 54 & $8 / 27 / 2013$ & 256.7 & $\mathrm{HCN}$ \\
\hline 5 & Trial 1 & $273.0 / 1280.4$ & 0017 & $4 / 11 / 2013$ & $5 / 31 / 2013$ & 197.7 & 55 & $6 / 5 / 2013$ & 239.0 & Euthanasia \\
\hline 5 & Trial 1 & 273.0/1280.4 & 0019 & $4 / 11 / 2013$ & $5 / 31 / 2013$ & 225.5 & 55 & $6 / 5 / 2013$ & 275.5 & $\mathrm{HCN}$ \\
\hline 5 & Trial 1 & 273.0/1280.4 & 0045 & $4 / 11 / 2013$ & $5 / 31 / 2013$ & 216.2 & 55 & $6 / 5 / 2013$ & 263.2 & Euthanasia \\
\hline 5 & Trial 1 & 273.0/1280.4 & 0047 & $4 / 11 / 2013$ & $5 / 31 / 2013$ & 214.6 & 55 & $6 / 5 / 2013$ & 251.7 & Euthanasia \\
\hline 5 & Trial 1 & 273.0/1280.4 & 0061 & $4 / 11 / 2013$ & $5 / 31 / 2013$ & 242.9 & 55 & $6 / 5 / 2013$ & 290.6 & Euthanasia \\
\hline 5 & Trial 1 & $273.0 / 1280.4$ & 0063 & $4 / 11 / 2013$ & $5 / 31 / 2013$ & 184.2 & 55 & $6 / 5 / 2013$ & 227.3 & $\mathrm{HCN}$ \\
\hline 5 & Trial 1 & 273.0/1280.4 & 0113 & $4 / 11 / 2013$ & $5 / 31 / 2013$ & 172.8 & 55 & $6 / 5 / 2013$ & 212.7 & Euthanasia \\
\hline 5 & Trial 1 & $273.0 / 1280.4$ & 0115 & $4 / 11 / 2013$ & $5 / 31 / 2013$ & 230.2 & 55 & $6 / 5 / 2013$ & 271.7 & Euthanasia \\
\hline 5 & Trial 1 & 273.0/1280.4 & 0149 & $4 / 11 / 2013$ & $5 / 31 / 2013$ & 215.2 & 55 & $6 / 5 / 2013$ & 258.3 & $\mathrm{HCN}$ \\
\hline 5 & Trial 1 & 273.0/1280.4 & 0151 & $4 / 11 / 2013$ & $5 / 31 / 2013$ & 203.1 & 55 & $6 / 5 / 2013$ & 245.6 & Euthanasia \\
\hline 5 & Trial 2 & 397.0/1941.7 & 0229 & $4 / 18 / 2013$ & $6 / 7 / 2013$ & 252.0 & 53 & $6 / 10 / 2013$ & 280.3 & $\mathrm{HCN}$ \\
\hline 5 & Trial 2 & 397.0/1941.7 & 0231 & $4 / 18 / 2013$ & $6 / 7 / 2013$ & 227.4 & 53 & $6 / 10 / 2013$ & 246.1 & $\mathrm{HCN}$ \\
\hline 5 & Trial 2 & 397.0/1941.7 & 0277 & $4 / 18 / 2013$ & 6/7/2013 & 239.1 & 53 & $6 / 10 / 2013$ & 267.0 & $\mathrm{HCN}$ \\
\hline
\end{tabular}




\begin{tabular}{|c|c|c|c|c|c|c|c|c|c|c|}
\hline $\begin{array}{l}\text { Profile } \\
(1-11)\end{array}$ & $\begin{array}{c}\text { Trial } \\
\text { Number }\end{array}$ & $\begin{array}{c}\text { Concentration } \\
(\mathrm{ppm})\end{array}$ & $\begin{array}{c}\text { Animal } \\
\#\end{array}$ & $\begin{array}{l}\text { Date of } \\
\text { Birth }\end{array}$ & $\begin{array}{c}\text { Date } \\
\text { Weighed }\end{array}$ & $\begin{array}{c}\text { Random- } \\
\text { ization } \\
\text { Weight (g) }\end{array}$ & $\begin{array}{c}\text { Age at } \\
\text { Exposure } \\
\text { (days) }\end{array}$ & $\begin{array}{c}\text { Date of } \\
\text { Exposure }\end{array}$ & $\begin{array}{c}\text { Weight at } \\
\text { Exposure } \\
\text { (g) }\end{array}$ & Mode of Death \\
\hline 5 & Trial 2 & $397.0 / 1941.7$ & 0279 & $4 / 18 / 2013$ & $6 / 7 / 2013$ & 231.3 & 53 & $6 / 10 / 2013$ & 257.1 & $\mathrm{HCN}$ \\
\hline 5 & Trial 2 & 397.0/1941.7 & 0281 & $4 / 18 / 2013$ & 6/7/2013 & 240.1 & 53 & $6 / 10 / 2013$ & 267.5 & $\mathrm{HCN}$ \\
\hline 5 & Trial 2 & $397.0 / 1941.7$ & 0283 & $4 / 18 / 2013$ & 6/7/2013 & 236.4 & 53 & $6 / 10 / 2013$ & 265.0 & $\mathrm{HCN}$ \\
\hline 5 & Trial 2 & $397.0 / 1941.7$ & 0317 & $4 / 18 / 2013$ & 6/7/2013 & 243.6 & 53 & $6 / 10 / 2013$ & 266.7 & $\mathrm{HCN}$ \\
\hline 5 & Trial 2 & 397.0/1941.7 & 0319 & $4 / 18 / 2013$ & 6/7/2013 & 224.8 & 53 & $6 / 10 / 2013$ & 250.2 & $\mathrm{HCN}$ \\
\hline 5 & Trial 2 & 397.0/1941.7 & 0385 & $4 / 18 / 2013$ & 6/7/2013 & 225.1 & 53 & $6 / 10 / 2013$ & 249.6 & $\mathrm{HCN}$ \\
\hline 5 & Trial 2 & 397.0/1941.7 & 0387 & $4 / 18 / 2013$ & $6 / 7 / 2013$ & 249.5 & 53 & $6 / 10 / 2013$ & 273.3 & $\mathrm{HCN}$ \\
\hline 5 & Trial 3 & $316.5 / 1574.7$ & 0481 & $4 / 25 / 2013$ & $6 / 14 / 2013$ & 233.5 & 53 & $6 / 17 / 2013$ & 260.3 & $\mathrm{HCN}$ \\
\hline 5 & Trial 3 & $316.5 / 1574.7$ & 0483 & $4 / 25 / 2013$ & $6 / 14 / 2013$ & 251.9 & 53 & $6 / 17 / 2013$ & 280.5 & Euthanasia \\
\hline 5 & Trial 3 & $316.5 / 1574.7$ & 0489 & $4 / 25 / 2013$ & $6 / 14 / 2013$ & 244.3 & 53 & $6 / 17 / 2013$ & 273.0 & Euthanasia \\
\hline 5 & Trial 3 & $316.5 / 1574.7$ & 0491 & $4 / 25 / 2013$ & $6 / 14 / 2013$ & 224.9 & 53 & $6 / 17 / 2013$ & 256.1 & $\mathrm{HCN}$ \\
\hline 5 & Trial 3 & $316.5 / 1574.7$ & 0497 & $4 / 25 / 2013$ & $6 / 14 / 2013$ & 247.3 & 53 & $6 / 17 / 2013$ & 281.7 & $\mathrm{HCN}$ \\
\hline 5 & Trial 3 & $316.5 / 1574.7$ & 0499 & $4 / 25 / 2013$ & $6 / 14 / 2013$ & 239.9 & 53 & $6 / 17 / 2013$ & 264.2 & Euthanasia \\
\hline 5 & Trial 3 & $316.5 / 1574.7$ & 0561 & $4 / 25 / 2013$ & $6 / 14 / 2013$ & 225.4 & 53 & $6 / 17 / 2013$ & 257.7 & Euthanasia \\
\hline 5 & Trial 3 & $316.5 / 1574.7$ & 0563 & $4 / 25 / 2013$ & $6 / 14 / 2013$ & 251.0 & 53 & $6 / 17 / 2013$ & 280.5 & $\mathrm{HCN}$ \\
\hline 5 & Trial 3 & $316.5 / 1574.7$ & 0597 & $4 / 25 / 2013$ & $6 / 14 / 2013$ & 250.4 & 53 & $6 / 17 / 2013$ & 277.2 & $\mathrm{HCN}$ \\
\hline 5 & Trial 3 & $316.5 / 1574.7$ & 0599 & $4 / 25 / 2013$ & $6 / 14 / 2013$ & 248.7 & 53 & $6 / 17 / 2013$ & 280.6 & $\mathrm{HCN}$ \\
\hline 5 & Trial 4 & 287.6/1409.1 & 0673 & $5 / 2 / 2013$ & $6 / 21 / 2013$ & 232.2 & 55 & $6 / 26 / 2013$ & 274.3 & $\mathrm{HCN}$ \\
\hline 5 & Trial 4 & 287.6/1409.1 & 0675 & $5 / 2 / 2013$ & $6 / 21 / 2013$ & 237.5 & 55 & $6 / 26 / 2013$ & 282.3 & $\mathrm{HCN}$ \\
\hline 5 & Trial 4 & 287.6/1409.1 & 0685 & $5 / 2 / 2013$ & $6 / 21 / 2013$ & 229.3 & 55 & $6 / 26 / 2013$ & 273.0 & Euthanasia \\
\hline 5 & Trial 4 & 287.6/1409.1 & 0687 & $5 / 2 / 2013$ & $6 / 21 / 2013$ & 233.5 & 55 & $6 / 26 / 2013$ & 277.1 & Euthanasia \\
\hline 5 & Trial 4 & 287.6/1409.1 & 0693 & $5 / 2 / 2013$ & $6 / 21 / 2013$ & 231.8 & 55 & $6 / 26 / 2013$ & 274.8 & Euthanasia \\
\hline 5 & Trial 4 & 287.6/1409.1 & 0695 & $5 / 2 / 2013$ & $6 / 21 / 2013$ & 229.7 & 55 & $6 / 26 / 2013$ & 272.4 & $\mathrm{HCN}$ \\
\hline 5 & Trial 4 & 287.6/1409.1 & 0789 & $5 / 2 / 2013$ & $6 / 21 / 2013$ & 223.8 & 55 & $6 / 26 / 2013$ & 266.1 & $\mathrm{HCN}$ \\
\hline 5 & Trial 4 & 287.6/1409.1 & 0791 & $5 / 2 / 2013$ & $6 / 21 / 2013$ & 244.2 & 55 & $6 / 26 / 2013$ & 291.5 & Euthanasia \\
\hline 5 & Trial 4 & 287.6/1409.1 & 0869 & $5 / 2 / 2013$ & $6 / 21 / 2013$ & 230.1 & 55 & $6 / 26 / 2013$ & 274.7 & $\mathrm{HCN}$ \\
\hline 5 & Trial 4 & 287.6/1409.1 & 0871 & $5 / 2 / 2013$ & $6 / 21 / 2013$ & 235.5 & 55 & $6 / 26 / 2013$ & 282.6 & Euthanasia \\
\hline 6 & Trial 1 & 290.0 & 0005 & $4 / 11 / 2013$ & $5 / 31 / 2013$ & 254.3 & 53 & $6 / 3 / 2013$ & 274.8 & $\mathrm{HCN}$ \\
\hline
\end{tabular}




\begin{tabular}{|c|c|c|c|c|c|c|c|c|c|c|}
\hline $\begin{array}{l}\text { Profile } \\
(1-11)\end{array}$ & $\begin{array}{c}\text { Trial } \\
\text { Number }\end{array}$ & $\begin{array}{c}\text { Concentration } \\
(\mathrm{ppm})\end{array}$ & $\begin{array}{c}\text { Animal } \\
\#\end{array}$ & $\begin{array}{l}\text { Date of } \\
\text { Birth }\end{array}$ & $\begin{array}{c}\text { Date } \\
\text { Weighed }\end{array}$ & $\begin{array}{c}\text { Random- } \\
\text { ization } \\
\text { Weight (g) }\end{array}$ & $\begin{array}{c}\text { Age at } \\
\text { Exposure } \\
\text { (days) }\end{array}$ & $\begin{array}{c}\text { Date of } \\
\text { Exposure }\end{array}$ & $\begin{array}{c}\text { Weight at } \\
\text { Exposure } \\
\text { (g) }\end{array}$ & Mode of Death \\
\hline 6 & Trial 1 & 290.0 & 0007 & $4 / 11 / 2013$ & $5 / 31 / 2013$ & 236.5 & 53 & $6 / 3 / 2013$ & 264.1 & Euthanasia \\
\hline 6 & Trial 1 & 290.0 & 0013 & $4 / 11 / 2013$ & $5 / 31 / 2013$ & 248.1 & 53 & $6 / 3 / 2013$ & 274.3 & $\mathrm{HCN}$ \\
\hline 6 & Trial 1 & 290.0 & 0015 & $4 / 11 / 2013$ & $5 / 31 / 2013$ & 210.7 & 53 & $6 / 3 / 2013$ & 233.4 & $\mathrm{HCN}$ \\
\hline 6 & Trial 1 & 290.0 & 0037 & $4 / 11 / 2013$ & $5 / 31 / 2013$ & 246.1 & 53 & $6 / 3 / 2013$ & 267.6 & Euthanasia \\
\hline 6 & Trial 1 & 290.0 & 0039 & $4 / 11 / 2013$ & $5 / 31 / 2013$ & 205.1 & 53 & $6 / 3 / 2013$ & 227.0 & $\mathrm{HCN}$ \\
\hline 6 & Trial 1 & 290.0 & 0201 & $4 / 11 / 2013$ & $5 / 31 / 2013$ & 241.7 & 53 & $6 / 3 / 2013$ & 270.1 & Euthanasia \\
\hline 6 & Trial 1 & 290.0 & 0203 & $4 / 11 / 2013$ & $5 / 31 / 2013$ & 227.1 & 53 & $6 / 3 / 2013$ & 251.8 & $\mathrm{HCN}$ \\
\hline 6 & Trial 1 & 290.0 & 0217 & $4 / 11 / 2013$ & $5 / 31 / 2013$ & 246.6 & 53 & $6 / 3 / 2013$ & 273.1 & $\mathrm{HCN}$ \\
\hline 6 & Trial 1 & 290.0 & 0219 & $4 / 11 / 2013$ & $5 / 31 / 2013$ & 228.7 & 53 & $6 / 3 / 2013$ & 252.9 & $\mathrm{HCN}$ \\
\hline 6 & Trial 2 & 220.3 & 0237 & $4 / 18 / 2013$ & $6 / 7 / 2013$ & 214.3 & 55 & $6 / 12 / 2013$ & 255.1 & $\mathrm{HCN}$ \\
\hline 6 & Trial 2 & 220.3 & 0239 & $4 / 18 / 2013$ & $6 / 7 / 2013$ & 227.6 & 55 & $6 / 12 / 2013$ & 266.7 & $\mathrm{HCN}$ \\
\hline 6 & Trial 2 & 220.3 & 0241 & $4 / 18 / 2013$ & $6 / 7 / 2013$ & 224.4 & 55 & $6 / 12 / 2013$ & 272.7 & Euthanasia \\
\hline 6 & Trial 2 & 220.3 & 0243 & $4 / 18 / 2013$ & $6 / 7 / 2013$ & 209.3 & 55 & $6 / 12 / 2013$ & 250.8 & Euthanasia \\
\hline 6 & Trial 2 & 220.3 & 0293 & $4 / 18 / 2013$ & 6/7/2013 & 202.6 & 55 & $6 / 12 / 2013$ & 247.0 & Euthanasia \\
\hline 6 & Trial 2 & 220.3 & 0295 & $4 / 18 / 2013$ & $6 / 7 / 2013$ & 243.3 & 55 & $6 / 12 / 2013$ & 281.5 & Euthanasia \\
\hline 6 & Trial 2 & 220.3 & 0329 & $4 / 18 / 2013$ & $6 / 7 / 2013$ & 218.1 & 55 & $6 / 12 / 2013$ & 261.0 & Euthanasia \\
\hline 6 & Trial 2 & 220.3 & 0331 & $4 / 18 / 2013$ & $6 / 7 / 2013$ & 220.8 & 55 & $6 / 12 / 2013$ & 260.1 & Euthanasia \\
\hline 6 & Trial 2 & 220.3 & 0389 & $4 / 18 / 2013$ & 6/7/2013 & 234.3 & 55 & $6 / 12 / 2013$ & 275.9 & Euthanasia \\
\hline 6 & Trial 2 & 220.3 & 0391 & $4 / 18 / 2013$ & 6/7/2013 & 210.2 & 55 & $6 / 12 / 2013$ & 249.2 & Euthanasia \\
\hline 7 & Trial 1 & $129.9 / 604.2$ & 0029 & $4 / 11 / 2013$ & $5 / 31 / 2013$ & 192.0 & 56 & $6 / 6 / 2013$ & 241.4 & $\mathrm{HCN}$ \\
\hline 7 & Trial 1 & $129.9 / 604.2$ & 0031 & $4 / 11 / 2013$ & $5 / 31 / 2013$ & 180.7 & 56 & 6/6/2013 & 219.7 & $\mathrm{HCN}$ \\
\hline 7 & Trial 1 & $129.9 / 604.2$ & 0085 & $4 / 11 / 2013$ & $5 / 31 / 2013$ & 201.3 & 56 & 6/6/2013 & 260.1 & $\mathrm{HCN}$ \\
\hline 7 & Trial 1 & $129.9 / 604.2$ & 0087 & $4 / 11 / 2013$ & $5 / 31 / 2013$ & 194.6 & 56 & $6 / 6 / 2013$ & 248.7 & Euthanasia \\
\hline 7 & Trial 1 & $129.9 / 604.2$ & 0093 & $4 / 11 / 2013$ & $5 / 31 / 2013$ & 183.7 & 56 & $6 / 6 / 2013$ & 231.4 & $\mathrm{HCN}$ \\
\hline 7 & Trial 1 & $129.9 / 604.2$ & 0095 & $4 / 11 / 2013$ & $5 / 31 / 2013$ & 197.8 & 56 & 6/6/2013 & 249.5 & Euthanasia \\
\hline 7 & Trial 1 & $129.9 / 604.2$ & 0121 & $4 / 11 / 2013$ & $5 / 31 / 2013$ & 186.6 & 56 & 6/6/2013 & 234.8 & $\mathrm{HCN}$ \\
\hline 7 & Trial 1 & $129.9 / 604.2$ & 0123 & $4 / 11 / 2013$ & $5 / 31 / 2013$ & 204.3 & 56 & 6/6/2013 & 248.9 & Euthanasia \\
\hline 7 & Trial 1 & $129.9 / 604.2$ & 0181 & $4 / 11 / 2013$ & $5 / 31 / 2013$ & 193.7 & 56 & 6/6/2013 & 253.9 & Euthanasia \\
\hline
\end{tabular}




\begin{tabular}{|c|c|c|c|c|c|c|c|c|c|c|}
\hline $\begin{array}{l}\text { Profile } \\
(1-11)\end{array}$ & $\begin{array}{c}\text { Trial } \\
\text { Number }\end{array}$ & $\begin{array}{c}\text { Concentration } \\
(\mathrm{ppm})\end{array}$ & $\begin{array}{c}\text { Animal } \\
\#\end{array}$ & $\begin{array}{l}\text { Date of } \\
\text { Birth }\end{array}$ & $\begin{array}{c}\text { Date } \\
\text { Weighed }\end{array}$ & $\begin{array}{c}\text { Random- } \\
\text { ization } \\
\text { Weight (g) }\end{array}$ & $\begin{array}{c}\text { Age at } \\
\text { Exposure } \\
\text { (days) }\end{array}$ & $\begin{array}{c}\text { Date of } \\
\text { Exposure }\end{array}$ & $\begin{array}{c}\text { Weight at } \\
\text { Exposure } \\
\text { (g) }\end{array}$ & Mode of Death \\
\hline 7 & Trial 1 & $129.9 / 604.2$ & 0183 & $4 / 11 / 2013$ & $5 / 31 / 2013$ & 206.1 & 56 & $6 / 6 / 2013$ & 268.7 & $\mathrm{HCN}$ \\
\hline 7 & Trial 2 & $91.6 / 455.3$ & 0225 & $4 / 18 / 2013$ & $6 / 7 / 2013$ & 228.7 & 55 & $6 / 12 / 2013$ & 273.0 & Euthanasia \\
\hline 7 & Trial 2 & $91.6 / 455.3$ & 0227 & $4 / 18 / 2013$ & $6 / 7 / 2013$ & 203.7 & 55 & $6 / 12 / 2013$ & 240.6 & Euthanasia \\
\hline 7 & Trial 2 & $91.6 / 455.3$ & 0261 & $4 / 18 / 2013$ & $6 / 7 / 2013$ & 220.5 & 55 & $6 / 12 / 2013$ & 263.8 & Euthanasia \\
\hline 7 & Trial 2 & $91.6 / 455.3$ & 0263 & $4 / 18 / 2013$ & $6 / 7 / 2013$ & 223.6 & 55 & $6 / 12 / 2013$ & 271.7 & Euthanasia \\
\hline 7 & Trial 2 & $91.6 / 455.3$ & 0297 & $4 / 18 / 2013$ & $6 / 7 / 2013$ & 215.4 & 55 & $6 / 12 / 2013$ & 253.2 & $\mathrm{HCN}$ \\
\hline 7 & Trial 2 & $91.6 / 455.3$ & 0299 & $4 / 18 / 2013$ & $6 / 7 / 2013$ & 224.5 & 55 & $6 / 12 / 2013$ & 256.7 & Euthanasia \\
\hline 7 & Trial 2 & $91.6 / 455.3$ & 0365 & $4 / 18 / 2013$ & 6/7/2013 & 221.0 & 55 & $6 / 12 / 2013$ & 271.6 & $\mathrm{HCN}$ \\
\hline 7 & Trial 2 & $91.6 / 455.3$ & 0367 & $4 / 18 / 2013$ & 6/7/2013 & 224.6 & 55 & $6 / 12 / 2013$ & 264.3 & Euthanasia \\
\hline 7 & Trial 2 & $91.6 / 455.3$ & 0377 & $4 / 18 / 2013$ & $6 / 7 / 2013$ & 229.5 & 55 & $6 / 12 / 2013$ & 275.1 & $\mathrm{HCN}$ \\
\hline 7 & Trial 2 & $91.6 / 455.3$ & 0379 & $4 / 18 / 2013$ & $6 / 7 / 2013$ & 207.9 & 55 & $6 / 12 / 2013$ & 247.1 & Euthanasia \\
\hline 7 & Trial 3 & $141.8 / 693.0$ & 0461 & $4 / 25 / 2013$ & $6 / 14 / 2013$ & 237.5 & 55 & $6 / 19 / 2013$ & 282.9 & $\mathrm{HCN}$ \\
\hline 7 & Trial 3 & $141.8 / 693.0$ & 0463 & $4 / 25 / 2013$ & $6 / 14 / 2013$ & 217.0 & 55 & $6 / 19 / 2013$ & 264.1 & $\mathrm{HCN}$ \\
\hline 7 & Trial 3 & $141.8 / 693.0$ & 0465 & $4 / 25 / 2013$ & $6 / 14 / 2013$ & 222.6 & 55 & $6 / 19 / 2013$ & 269.3 & $\mathrm{HCN}$ \\
\hline 7 & Trial 3 & $141.8 / 693.0$ & 0467 & $4 / 25 / 2013$ & $6 / 14 / 2013$ & 237.7 & 55 & $6 / 19 / 2013$ & 291.1 & $\mathrm{HCN}$ \\
\hline 7 & Trial 3 & $141.8 / 693.0$ & 0493 & $4 / 25 / 2013$ & $6 / 14 / 2013$ & 225.2 & 55 & $6 / 19 / 2013$ & 275.7 & Euthanasia \\
\hline 7 & Trial 3 & $141.8 / 693.0$ & 0495 & $4 / 25 / 2013$ & $6 / 14 / 2013$ & 227.6 & 55 & $6 / 19 / 2013$ & 269.5 & $\mathrm{HCN}$ \\
\hline 7 & Trial 3 & $141.8 / 693.0$ & 0545 & $4 / 25 / 2013$ & $6 / 14 / 2013$ & 223.8 & 55 & $6 / 19 / 2013$ & 262.9 & $\mathrm{HCN}$ \\
\hline 7 & Trial 3 & $141.8 / 693.0$ & 0547 & $4 / 25 / 2013$ & $6 / 14 / 2013$ & 233.7 & 55 & $6 / 19 / 2013$ & 272.3 & $\mathrm{HCN}$ \\
\hline 7 & Trial 3 & $141.8 / 693.0$ & 0569 & $4 / 25 / 2013$ & $6 / 14 / 2013$ & 236.8 & 55 & $6 / 19 / 2013$ & 287.9 & Euthanasia \\
\hline 7 & Trial 3 & $141.8 / 693.0$ & 0571 & $4 / 25 / 2013$ & $6 / 14 / 2013$ & 223.7 & 55 & $6 / 19 / 2013$ & 270.8 & $\mathrm{HCN}$ \\
\hline 7 & Trial 4 & $104.8 / 523.9$ & 0665 & $5 / 2 / 2013$ & $6 / 21 / 2013$ & 241.2 & 56 & $6 / 27 / 2013$ & 295.5 & Euthanasia \\
\hline 7 & Trial 4 & $104.8 / 523.9$ & 0667 & $5 / 2 / 2013$ & $6 / 21 / 2013$ & 207.9 & 56 & $6 / 27 / 2013$ & 260.5 & Euthanasia \\
\hline 7 & Trial 4 & $104.8 / 523.9$ & 0705 & $5 / 2 / 2013$ & $6 / 21 / 2013$ & 235.6 & 56 & $6 / 27 / 2013$ & 292.5 & Euthanasia \\
\hline 7 & Trial 4 & $104.8 / 523.9$ & 0707 & $5 / 2 / 2013$ & $6 / 21 / 2013$ & 224.8 & 56 & $6 / 27 / 2013$ & 274.3 & $\mathrm{HCN}$ \\
\hline 7 & Trial 4 & $104.8 / 523.9$ & 0725 & $5 / 2 / 2013$ & $6 / 21 / 2013$ & 218.5 & 56 & $6 / 27 / 2013$ & 267.1 & Euthanasia \\
\hline 7 & Trial 4 & $104.8 / 523.9$ & 0727 & $5 / 2 / 2013$ & $6 / 21 / 2013$ & 237.0 & 56 & $6 / 27 / 2013$ & 295.0 & Euthanasia \\
\hline 7 & Trial 4 & $104.8 / 523.9$ & 0777 & $5 / 2 / 2013$ & 6/21/2013 & 238.9 & 56 & $6 / 27 / 2013$ & 287.3 & Euthanasia \\
\hline
\end{tabular}




\begin{tabular}{|c|c|c|c|c|c|c|c|c|c|c|}
\hline $\begin{array}{l}\text { Profile } \\
(1-11)\end{array}$ & $\begin{array}{c}\text { Trial } \\
\text { Number }\end{array}$ & $\begin{array}{l}\text { Concentration } \\
(\mathrm{ppm})\end{array}$ & $\begin{array}{c}\text { Animal } \\
\#\end{array}$ & $\begin{array}{l}\text { Date of } \\
\text { Birth }\end{array}$ & $\begin{array}{c}\text { Date } \\
\text { Weighed }\end{array}$ & $\begin{array}{c}\text { Random- } \\
\text { ization } \\
\text { Weight (g) }\end{array}$ & $\begin{array}{c}\text { Age at } \\
\text { Exposure } \\
\text { (days) }\end{array}$ & $\begin{array}{c}\text { Date of } \\
\text { Exposure }\end{array}$ & $\begin{array}{c}\text { Weight at } \\
\text { Exposure } \\
\text { (g) }\end{array}$ & Mode of Death \\
\hline 7 & Trial 4 & $104.8 / 523.9$ & 0779 & $5 / 2 / 2013$ & $6 / 21 / 2013$ & 218.3 & 56 & $6 / 27 / 2013$ & 265.4 & Euthanasia \\
\hline 7 & Trial 4 & $104.8 / 523.9$ & 0797 & $5 / 2 / 2013$ & $6 / 21 / 2013$ & 222.4 & 56 & $6 / 27 / 2013$ & 274.3 & Euthanasia \\
\hline 7 & Trial 4 & $104.8 / 523.9$ & 0799 & $5 / 2 / 2013$ & $6 / 21 / 2013$ & 224.0 & 56 & $6 / 27 / 2013$ & 270.1 & $\mathrm{HCN}$ \\
\hline 7 & Trial 5 & $81.2 / 406.8$ & 0881 & $5 / 9 / 2013$ & $6 / 28 / 2013$ & 208.0 & 53 & $7 / 1 / 2013$ & 230.9 & Euthanasia \\
\hline 7 & Trial 5 & $81.2 / 406.8$ & 0883 & $5 / 9 / 2013$ & $6 / 28 / 2013$ & 225.4 & 53 & $7 / 1 / 2013$ & 253.3 & $\mathrm{HCN}$ \\
\hline 7 & Trial 5 & $81.2 / 406.8$ & 0885 & $5 / 9 / 2013$ & $6 / 28 / 2013$ & 243.7 & 53 & 7/1/2013 & 271.3 & $\mathrm{HCN}$ \\
\hline 7 & Trial 5 & $81.2 / 406.8$ & 0887 & $5 / 9 / 2013$ & $6 / 28 / 2013$ & 242.3 & 53 & $7 / 1 / 2013$ & 269.0 & Euthanasia \\
\hline 7 & Trial 5 & $81.2 / 406.8$ & 0917 & $5 / 9 / 2013$ & $6 / 28 / 2013$ & 237.1 & 53 & $7 / 1 / 2013$ & 266.1 & $\mathrm{HCN}$ \\
\hline 7 & Trial 5 & $81.2 / 406.8$ & 0919 & $5 / 9 / 2013$ & $6 / 28 / 2013$ & 214.1 & 53 & $7 / 1 / 2013$ & 235.5 & Euthanasia \\
\hline 7 & Trial 5 & $81.2 / 406.8$ & 0941 & $5 / 9 / 2013$ & $6 / 28 / 2013$ & 213.3 & 53 & $7 / 1 / 2013$ & 238.4 & $\mathrm{HCN}$ \\
\hline 7 & Trial 5 & $81.2 / 406.8$ & 0943 & $5 / 9 / 2013$ & $6 / 28 / 2013$ & 232.4 & 53 & $7 / 1 / 2013$ & 257.3 & Euthanasia \\
\hline 7 & Trial 5 & $81.2 / 406.8$ & 0977 & $5 / 9 / 2013$ & $6 / 28 / 2013$ & 213.7 & 53 & $7 / 1 / 2013$ & 239.4 & $\mathrm{HCN}$ \\
\hline 7 & Trial 5 & $81.2 / 406.8$ & 0979 & $5 / 9 / 2013$ & $6 / 28 / 2013$ & 245.4 & 53 & $7 / 1 / 2013$ & 273.4 & Euthanasia \\
\hline 7 & Trial 6 & $69.9 / 355.7$ & 1101 & $7 / 4 / 2013$ & $8 / 23 / 2013$ & 242.5 & 53 & $8 / 26 / 2013$ & 271.1 & Euthanasia \\
\hline 7 & Trial 6 & $69.9 / 355.7$ & 1103 & $7 / 4 / 2013$ & $8 / 23 / 2013$ & 236.0 & 53 & $8 / 26 / 2013$ & 264.6 & Euthanasia \\
\hline 7 & Trial 6 & $69.9 / 355.7$ & 1113 & $7 / 4 / 2013$ & $8 / 23 / 2013$ & 245.0 & 53 & $8 / 26 / 2013$ & 276.8 & Euthanasia \\
\hline 7 & Trial 6 & $69.9 / 355.7$ & 1115 & $7 / 4 / 2013$ & $8 / 23 / 2013$ & 239.7 & 53 & $8 / 26 / 2013$ & 271.8 & $\mathrm{HCN}$ \\
\hline 7 & Trial 6 & $69.9 / 355.7$ & 1177 & $7 / 4 / 2013$ & $8 / 23 / 2013$ & 257.8 & 53 & $8 / 26 / 2013$ & 286.3 & $\mathrm{HCN}$ \\
\hline 7 & Trial 6 & $69.9 / 355.7$ & 1179 & $7 / 4 / 2013$ & $8 / 23 / 2013$ & 236.3 & 53 & $8 / 26 / 2013$ & 264.1 & $\mathrm{HCN}$ \\
\hline 7 & Trial 6 & $69.9 / 355.7$ & 1185 & $7 / 4 / 2013$ & $8 / 23 / 2013$ & 253.0 & 53 & $8 / 26 / 2013$ & 285.1 & Euthanasia \\
\hline 7 & Trial 6 & $69.9 / 355.7$ & 1187 & $7 / 4 / 2013$ & $8 / 23 / 2013$ & 251.1 & 53 & $8 / 26 / 2013$ & 278.5 & $\mathrm{HCN}$ \\
\hline 7 & Trial 6 & $69.9 / 355.7$ & 1189 & $7 / 4 / 2013$ & $8 / 23 / 2013$ & 266.0 & 53 & $8 / 26 / 2013$ & 303.6 & Euthanasia \\
\hline 7 & Trial 6 & $69.9 / 355.7$ & 1191 & $7 / 4 / 2013$ & $8 / 23 / 2013$ & 258.5 & 53 & $8 / 26 / 2013$ & 288.4 & Euthanasia \\
\hline 8 & Trial 1 & $94.0 / 472.0$ & 0033 & $4 / 11 / 2013$ & $5 / 31 / 2013$ & 216.5 & 54 & $6 / 4 / 2013$ & 247.0 & $\mathrm{HCN}$ \\
\hline 8 & Trial 1 & $94.0 / 472.0$ & 0035 & $4 / 11 / 2013$ & $5 / 31 / 2013$ & 230.4 & 54 & $6 / 4 / 2013$ & 257.2 & $\mathrm{HCN}$ \\
\hline 8 & Trial 1 & $94.0 / 472.0$ & 0117 & $4 / 11 / 2013$ & $5 / 31 / 2013$ & 228.2 & 54 & $6 / 4 / 2013$ & 259.2 & $\mathrm{HCN}$ \\
\hline 8 & Trial 1 & $94.0 / 472.0$ & 0119 & $4 / 11 / 2013$ & $5 / 31 / 2013$ & 204.5 & 54 & $6 / 4 / 2013$ & 240.2 & Euthanasia \\
\hline 8 & Trial 1 & $94.0 / 472.0$ & 0133 & $4 / 11 / 2013$ & $5 / 31 / 2013$ & 216.9 & 54 & $6 / 4 / 2013$ & 241.2 & Euthanasia \\
\hline
\end{tabular}




\begin{tabular}{|c|c|c|c|c|c|c|c|c|c|c|}
\hline $\begin{array}{l}\text { Profile } \\
(1-11)\end{array}$ & $\begin{array}{c}\text { Trial } \\
\text { Number }\end{array}$ & $\begin{array}{c}\text { Concentration } \\
(\mathrm{ppm})\end{array}$ & $\begin{array}{c}\text { Animal } \\
\#\end{array}$ & $\begin{array}{l}\text { Date of } \\
\text { Birth }\end{array}$ & $\begin{array}{c}\text { Date } \\
\text { Weighed }\end{array}$ & $\begin{array}{l}\text { Random- } \\
\text { ization } \\
\text { Weight }(\mathrm{g})\end{array}$ & $\begin{array}{c}\text { Age at } \\
\text { Exposure } \\
\text { (days) }\end{array}$ & $\begin{array}{c}\text { Date of } \\
\text { Exposure }\end{array}$ & $\begin{array}{c}\text { Weight at } \\
\text { Exposure } \\
(\mathrm{g})\end{array}$ & Mode of Death \\
\hline 8 & Trial 1 & $94.0 / 472.0$ & 0135 & $4 / 11 / 2013$ & $5 / 31 / 2013$ & 225.0 & 54 & $6 / 4 / 2013$ & 265.8 & Euthanasia \\
\hline 8 & Trial 1 & $94.0 / 472.0$ & 0161 & $4 / 11 / 2013$ & $5 / 31 / 2013$ & 214.4 & 54 & $6 / 4 / 2013$ & 246.4 & $\mathrm{HCN}$ \\
\hline 8 & Trial 1 & $94.0 / 472.0$ & 0163 & $4 / 11 / 2013$ & $5 / 31 / 2013$ & 220.9 & 54 & $6 / 4 / 2013$ & 256.8 & $\mathrm{HCN}$ \\
\hline 8 & Trial 1 & $94.0 / 472.0$ & 0197 & $4 / 11 / 2013$ & $5 / 31 / 2013$ & 233.3 & 54 & $6 / 4 / 2013$ & 269.0 & Euthanasia \\
\hline 8 & Trial 1 & $94.0 / 472.0$ & 0199 & $4 / 11 / 2013$ & $5 / 31 / 2013$ & 217.0 & 54 & $6 / 4 / 2013$ & 249.1 & $\mathrm{HCN}$ \\
\hline 8 & Trial 2 & $71.2 / 359.7$ & 0249 & $4 / 18 / 2013$ & $6 / 7 / 2013$ & 219.2 & 54 & $6 / 11 / 2013$ & 246.5 & $\mathrm{HCN}$ \\
\hline 8 & Trial 2 & $71.2 / 359.7$ & 0251 & $4 / 18 / 2013$ & 6/7/2013 & 233.0 & 54 & $6 / 11 / 2013$ & 269.6 & Euthanasia \\
\hline 8 & Trial 2 & $71.2 / 359.7$ & 0305 & $4 / 18 / 2013$ & 6/7/2013 & 220.4 & 54 & $6 / 11 / 2013$ & 257.0 & $\mathrm{HCN}$ \\
\hline 8 & Trial 2 & $71.2 / 359.7$ & 0307 & $4 / 18 / 2013$ & 6/7/2013 & 225.8 & 54 & $6 / 11 / 2013$ & 259.0 & $\mathrm{HCN}$ \\
\hline 8 & Trial 2 & $71.2 / 359.7$ & 0337 & $4 / 18 / 2013$ & 6/7/2013 & 233.4 & 54 & $6 / 11 / 2013$ & 269.1 & Euthanasia \\
\hline 8 & Trial 2 & $71.2 / 359.7$ & 0339 & $4 / 18 / 2013$ & 6/7/2013 & 233.9 & 54 & $6 / 11 / 2013$ & 275.8 & $\mathrm{HCN}$ \\
\hline 8 & Trial 2 & $71.2 / 359.7$ & 0345 & $4 / 18 / 2013$ & 6/7/2013 & 232.7 & 54 & $6 / 11 / 2013$ & 266.5 & Euthanasia \\
\hline 8 & Trial 2 & $71.2 / 359.7$ & 0347 & $4 / 18 / 2013$ & 6/7/2013 & 216.8 & 54 & $6 / 11 / 2013$ & 249.2 & Euthanasia \\
\hline 8 & Trial 2 & $71.2 / 359.7$ & 0421 & $4 / 18 / 2013$ & 6/7/2013 & 213.2 & 54 & $6 / 11 / 2013$ & 237.1 & Euthanasia \\
\hline 8 & Trial 2 & $71.2 / 359.7$ & 0423 & $4 / 18 / 2013$ & 6/7/2013 & 245.3 & 54 & $6 / 11 / 2013$ & 288.7 & Euthanasia \\
\hline 8 & Trial 3 & $62.1 / 314.5$ & 0469 & $4 / 25 / 2013$ & $6 / 14 / 2013$ & 246.7 & 54 & $6 / 18 / 2013$ & 276.6 & Euthanasia \\
\hline 8 & Trial 3 & $62.1 / 314.5$ & 0471 & $4 / 25 / 2013$ & $6 / 14 / 2013$ & 219.4 & 54 & $6 / 18 / 2013$ & 255.8 & Euthanasia \\
\hline 8 & Trial 3 & $62.1 / 314.5$ & 0473 & $4 / 25 / 2013$ & $6 / 14 / 2013$ & 226.9 & 54 & $6 / 18 / 2013$ & 262.5 & Euthanasia \\
\hline 8 & Trial 3 & $62.1 / 314.5$ & 0475 & $4 / 25 / 2013$ & $6 / 14 / 2013$ & 240.1 & 54 & $6 / 18 / 2013$ & 275.0 & Euthanasia \\
\hline 8 & Trial 3 & $62.1 / 314.5$ & 0553 & $4 / 25 / 2013$ & $6 / 14 / 2013$ & 233.5 & 54 & $6 / 18 / 2013$ & 270.6 & Euthanasia \\
\hline 8 & Trial 3 & $62.1 / 314.5$ & 0555 & $4 / 25 / 2013$ & $6 / 14 / 2013$ & 230.2 & 54 & $6 / 18 / 2013$ & 269.6 & Euthanasia \\
\hline 8 & Trial 3 & $62.1 / 314.5$ & 0565 & $4 / 25 / 2013$ & $6 / 14 / 2013$ & 229.8 & 54 & $6 / 18 / 2013$ & 270.1 & Euthanasia \\
\hline 8 & Trial 3 & $62.1 / 314.5$ & 0567 & $4 / 25 / 2013$ & $6 / 14 / 2013$ & 233.0 & 54 & $6 / 18 / 2013$ & 265.2 & Euthanasia \\
\hline 8 & Trial 3 & $62.1 / 314.5$ & 0653 & $4 / 25 / 2013$ & $6 / 14 / 2013$ & 228.2 & 54 & $6 / 18 / 2013$ & 264.6 & Euthanasia \\
\hline 8 & Trial 3 & $62.1 / 314.5$ & 0655 & $4 / 25 / 2013$ & $6 / 14 / 2013$ & 239.6 & 54 & $6 / 18 / 2013$ & 280.0 & Euthanasia \\
\hline 8 & Trial 4 & $108.5 / 543.0$ & 0761 & $5 / 2 / 2013$ & $6 / 21 / 2013$ & 235.7 & 55 & $6 / 26 / 2013$ & 285.1 & $\mathrm{HCN}$ \\
\hline 8 & Trial 4 & $108.5 / 543.0$ & 0763 & $5 / 2 / 2013$ & $6 / 21 / 2013$ & 231.1 & 55 & $6 / 26 / 2013$ & 278.0 & $\mathrm{HCN}$ \\
\hline 8 & Trial 4 & $108.5 / 543.0$ & 0805 & $5 / 2 / 2013$ & $6 / 21 / 2013$ & 230.1 & 55 & $6 / 26 / 2013$ & 274.8 & $\mathrm{HCN}$ \\
\hline
\end{tabular}




\begin{tabular}{|c|c|c|c|c|c|c|c|c|c|c|}
\hline $\begin{array}{l}\text { Profile } \\
(1-11)\end{array}$ & $\begin{array}{c}\text { Trial } \\
\text { Number }\end{array}$ & $\begin{array}{l}\text { Concentration } \\
(\mathrm{ppm})\end{array}$ & $\begin{array}{c}\text { Animal } \\
\#\end{array}$ & $\begin{array}{l}\text { Date of } \\
\text { Birth }\end{array}$ & $\begin{array}{c}\text { Date } \\
\text { Weighed }\end{array}$ & $\begin{array}{c}\text { Random- } \\
\text { ization } \\
\text { Weight (g) }\end{array}$ & $\begin{array}{c}\text { Age at } \\
\text { Exposure } \\
\text { (days) }\end{array}$ & $\begin{array}{c}\text { Date of } \\
\text { Exposure }\end{array}$ & $\begin{array}{c}\text { Weight at } \\
\text { Exposure } \\
\text { (g) }\end{array}$ & Mode of Death \\
\hline 8 & Trial 4 & $108.5 / 543.0$ & 0807 & $5 / 2 / 2013$ & $6 / 21 / 2013$ & 230.7 & 55 & $6 / 26 / 2013$ & 281.4 & $\mathrm{HCN}$ \\
\hline 8 & Trial 4 & $108.5 / 543.0$ & 0833 & $5 / 2 / 2013$ & $6 / 21 / 2013$ & 236.5 & 55 & $6 / 26 / 2013$ & 275.0 & $\mathrm{HCN}$ \\
\hline 8 & Trial 4 & $108.5 / 543.0$ & 0835 & $5 / 2 / 2013$ & $6 / 21 / 2013$ & 225.8 & 55 & $6 / 26 / 2013$ & 273.4 & $\mathrm{HCN}$ \\
\hline 8 & Trial 4 & $108.5 / 543.0$ & 0873 & $5 / 2 / 2013$ & $6 / 21 / 2013$ & 228.9 & 55 & $6 / 26 / 2013$ & 266.5 & Euthanasia \\
\hline 8 & Trial 4 & $108.5 / 543.0$ & 0875 & $5 / 2 / 2013$ & $6 / 21 / 2013$ & 236.7 & 55 & $6 / 26 / 2013$ & 276.3 & $\mathrm{HCN}$ \\
\hline 8 & Trial 4 & $108.5 / 543.0$ & 0877 & $5 / 2 / 2013$ & $6 / 21 / 2013$ & 238.1 & 55 & $6 / 26 / 2013$ & 297.7 & $\mathrm{HCN}$ \\
\hline 8 & Trial 4 & $108.5 / 543.0$ & 0879 & $5 / 2 / 2013$ & $6 / 21 / 2013$ & 231.4 & 55 & $6 / 26 / 2013$ & 269.6 & $\mathrm{HCN}$ \\
\hline 9 & Trial 1 & $175.5 / 854.4$ & 0309 & $4 / 18 / 2013$ & 6/7/2013 & 235.3 & 53 & $6 / 10 / 2013$ & 267.2 & $\begin{array}{c}\text { Cause } \\
\text { Undetermined }^{a}\end{array}$ \\
\hline 9 & Trial 1 & $175.5 / 854.4$ & 0311 & $4 / 18 / 2013$ & $6 / 7 / 2013$ & 245.6 & 53 & $6 / 10 / 2013$ & 270.0 & Euthanasia \\
\hline 9 & Trial 1 & $175.5 / 854.4$ & 0357 & $4 / 18 / 2013$ & 6/7/2013 & 253.0 & 53 & $6 / 10 / 2013$ & 277.8 & $\mathrm{HCN}$ \\
\hline 9 & Trial 1 & $175.5 / 854.4$ & 0359 & $4 / 18 / 2013$ & $6 / 7 / 2013$ & 221.7 & 53 & $6 / 10 / 2013$ & 244.5 & $\mathrm{HCN}$ \\
\hline 9 & Trial 1 & $175.5 / 854.4$ & 0381 & $4 / 18 / 2013$ & $6 / 7 / 2013$ & 231.2 & 53 & $6 / 10 / 2013$ & 260.6 & $\mathrm{HCN}$ \\
\hline 9 & Trial 1 & $175.5 / 854.4$ & 0383 & $4 / 18 / 2013$ & 6/7/2013 & 238.0 & 53 & $6 / 10 / 2013$ & 262.5 & $\mathrm{HCN}$ \\
\hline 9 & Trial 1 & $175.5 / 854.4$ & 0409 & $4 / 18 / 2013$ & $6 / 7 / 2013$ & 248.3 & 53 & $6 / 10 / 2013$ & 284.9 & Euthanasia \\
\hline 9 & Trial 1 & $175.5 / 854.4$ & 0411 & $4 / 18 / 2013$ & $6 / 7 / 2013$ & 224.2 & 53 & $6 / 10 / 2013$ & 251.5 & $\mathrm{HCN}$ \\
\hline 9 & Trial 1 & $175.5 / 854.4$ & 0417 & $4 / 18 / 2013$ & $6 / 7 / 2013$ & 248.7 & 53 & $6 / 10 / 2013$ & 278.3 & $\mathrm{HCN}$ \\
\hline 9 & Trial 1 & $175.5 / 854.4$ & 0419 & $4 / 18 / 2013$ & 6/7/2013 & 229.2 & 53 & $6 / 10 / 2013$ & 255.1 & $\mathrm{HCN}$ \\
\hline 9 & Trial 2 & $135.0 / 685.2$ & 0221 & $4 / 18 / 2013$ & 6/7/2013 & 206.2 & 56 & $6 / 13 / 2013$ & 261.4 & Euthanasia \\
\hline 9 & Trial 2 & $135.0 / 685.2$ & 0223 & $4 / 18 / 2013$ & 6/7/2013 & 202.8 & 56 & $6 / 13 / 2013$ & 257.2 & Euthanasia \\
\hline 9 & Trial 2 & $135.0 / 685.2$ & 0233 & $4 / 18 / 2013$ & $6 / 7 / 2013$ & 216.5 & 56 & $6 / 13 / 2013$ & 270.4 & Euthanasia \\
\hline 9 & Trial 2 & $135.0 / 685.2$ & 0235 & $4 / 18 / 2013$ & $6 / 7 / 2013$ & 207.8 & 56 & $6 / 13 / 2013$ & 254.8 & Euthanasia \\
\hline 9 & Trial 2 & $135.0 / 685.2$ & 0265 & $4 / 18 / 2013$ & 6/7/2013 & 200.2 & 56 & $6 / 13 / 2013$ & 254.0 & Euthanasia \\
\hline 9 & Trial 2 & $135.0 / 685.2$ & 0267 & $4 / 18 / 2013$ & $6 / 7 / 2013$ & 204.8 & 56 & $6 / 13 / 2013$ & 269.1 & $\mathrm{HCN}$ \\
\hline 9 & Trial 2 & $135.0 / 685.2$ & 0333 & $4 / 18 / 2013$ & $6 / 7 / 2013$ & 219.3 & 56 & $6 / 13 / 2013$ & 267.1 & Euthanasia \\
\hline 9 & Trial 2 & $135.0 / 685.2$ & 0335 & $4 / 18 / 2013$ & $6 / 7 / 2013$ & 206.1 & 56 & $6 / 13 / 2013$ & 255.1 & $\mathrm{HCN}$ \\
\hline 9 & Trial 2 & $135.0 / 685.2$ & 0425 & $4 / 18 / 2013$ & $6 / 7 / 2013$ & 214.5 & 56 & $6 / 13 / 2013$ & 259.4 & Euthanasia \\
\hline 9 & Trial 2 & $135.0 / 685.2$ & 0427 & $4 / 18 / 2013$ & $6 / 7 / 2013$ & 203.8 & 56 & $6 / 13 / 2013$ & 249.9 & Euthanasia \\
\hline
\end{tabular}




\begin{tabular}{|c|c|c|c|c|c|c|c|c|c|c|}
\hline $\begin{array}{l}\text { Profile } \\
(1-11)\end{array}$ & $\begin{array}{c}\text { Trial } \\
\text { Number }\end{array}$ & $\begin{array}{l}\text { Concentration } \\
(\mathrm{ppm})\end{array}$ & $\begin{array}{c}\text { Animal } \\
\#\end{array}$ & $\begin{array}{l}\text { Date of } \\
\text { Birth }\end{array}$ & $\begin{array}{c}\text { Date } \\
\text { Weighed }\end{array}$ & $\begin{array}{c}\text { Random- } \\
\text { ization } \\
\text { Weight (g) }\end{array}$ & $\begin{array}{c}\text { Age at } \\
\text { Exposure } \\
\text { (days) }\end{array}$ & $\begin{array}{c}\text { Date of } \\
\text { Exposure }\end{array}$ & $\begin{array}{c}\text { Weight at } \\
\text { Exposure } \\
\text { (g) }\end{array}$ & Mode of Death \\
\hline 9 & Trial 3 & $153.9 / 762.9$ & 0445 & $4 / 25 / 2013$ & $6 / 14 / 2013$ & 211.3 & 56 & $6 / 20 / 2013$ & 259.9 & $\mathrm{HCN}$ \\
\hline 9 & Trial 3 & $153.9 / 762.9$ & 0447 & $4 / 25 / 2013$ & $6 / 14 / 2013$ & 229.2 & 56 & $6 / 20 / 2013$ & 283.6 & $\mathrm{HCN}$ \\
\hline 9 & Trial 3 & $153.9 / 762.9$ & 0457 & $4 / 25 / 2013$ & $6 / 14 / 2013$ & 211.1 & 56 & $6 / 20 / 2013$ & 257.4 & $\mathrm{HCN}$ \\
\hline 9 & Trial 3 & $153.9 / 762.9$ & 0459 & $4 / 25 / 2013$ & $6 / 14 / 2013$ & 213.1 & 56 & $6 / 20 / 2013$ & 257.0 & $\mathrm{HCN}$ \\
\hline 9 & Trial 3 & $153.9 / 762.9$ & 0517 & $4 / 25 / 2013$ & $6 / 14 / 2013$ & 225.5 & 56 & $6 / 20 / 2013$ & 287.1 & $\mathrm{HCN}$ \\
\hline 9 & Trial 3 & $153.9 / 762.9$ & 0519 & $4 / 25 / 2013$ & $6 / 14 / 2013$ & 225.4 & 56 & $6 / 20 / 2013$ & 274.4 & $\mathrm{HCN}$ \\
\hline 9 & Trial 3 & $153.9 / 762.9$ & 0521 & $4 / 25 / 2013$ & $6 / 14 / 2013$ & 226.9 & 56 & $6 / 20 / 2013$ & 286.5 & Euthanasia \\
\hline 9 & Trial 3 & $153.9 / 762.9$ & 0523 & $4 / 25 / 2013$ & $6 / 14 / 2013$ & 216.1 & 56 & $6 / 20 / 2013$ & 268.8 & $\mathrm{HCN}$ \\
\hline 9 & Trial 3 & $153.9 / 762.9$ & 0601 & $4 / 25 / 2013$ & $6 / 14 / 2013$ & 211.8 & 56 & $6 / 20 / 2013$ & 255.0 & Euthanasia \\
\hline 9 & Trial 3 & $153.9 / 762.9$ & 0603 & $4 / 25 / 2013$ & $6 / 14 / 2013$ & 223.2 & 56 & $6 / 20 / 2013$ & 284.7 & $\mathrm{HCN}$ \\
\hline 9 & Trial 4 & $128.0 / 641.8$ & 0721 & $5 / 2 / 2013$ & $6 / 21 / 2013$ & 238.5 & 53 & $6 / 24 / 2013$ & 266.4 & Euthanasia \\
\hline 9 & Trial 4 & $128.0 / 641.8$ & 0723 & $5 / 2 / 2013$ & $6 / 21 / 2013$ & 242.6 & 53 & $6 / 24 / 2013$ & 267.5 & $\mathrm{HCN}$ \\
\hline 9 & Trial 4 & $128.0 / 641.8$ & 0757 & $5 / 2 / 2013$ & $6 / 21 / 2013$ & 245.9 & 53 & $6 / 24 / 2013$ & 276.3 & Euthanasia \\
\hline 9 & Trial 4 & $128.0 / 641.8$ & 0759 & $5 / 2 / 2013$ & $6 / 21 / 2013$ & 250.9 & 53 & $6 / 24 / 2013$ & 280.7 & Euthanasia \\
\hline 9 & Trial 4 & $128.0 / 641.8$ & 0765 & $5 / 2 / 2013$ & $6 / 21 / 2013$ & 237.5 & 53 & $6 / 24 / 2013$ & 263.2 & Euthanasia \\
\hline 9 & Trial 4 & $128.0 / 641.8$ & 0767 & $5 / 2 / 2013$ & $6 / 21 / 2013$ & 246.8 & 53 & $6 / 24 / 2013$ & 277.3 & $\mathrm{HCN}$ \\
\hline 9 & Trial 4 & $128.0 / 641.8$ & 0825 & $5 / 2 / 2013$ & $6 / 21 / 2013$ & 254.5 & 53 & $6 / 24 / 2013$ & 280.2 & Euthanasia \\
\hline 9 & Trial 4 & $128.0 / 641.8$ & 0827 & $5 / 2 / 2013$ & $6 / 21 / 2013$ & 235.0 & 53 & $6 / 24 / 2013$ & 267.1 & Euthanasia \\
\hline 9 & Trial 4 & $128.0 / 641.8$ & 0845 & $5 / 2 / 2013$ & $6 / 21 / 2013$ & 237.6 & 53 & $6 / 24 / 2013$ & 264.0 & Euthanasia \\
\hline 9 & Trial 4 & $128.0 / 641.8$ & 0847 & $5 / 2 / 2013$ & $6 / 21 / 2013$ & 244.9 & 53 & $6 / 24 / 2013$ & 270.7 & Euthanasia \\
\hline 9 & Trial 5 & $144.2 / 722.4$ & 0741 & $5 / 2 / 2013$ & $6 / 21 / 2013$ & 233.1 & 56 & $6 / 27 / 2013$ & 294.5 & Euthanasia \\
\hline 9 & Trial 5 & $144.2 / 722.4$ & 0743 & $5 / 2 / 2013$ & $6 / 21 / 2013$ & 226.3 & 56 & $6 / 27 / 2013$ & 275.5 & $\mathrm{HCN}$ \\
\hline 9 & Trial 5 & $144.2 / 722.4$ & 0745 & $5 / 2 / 2013$ & $6 / 21 / 2013$ & 233.9 & 56 & $6 / 27 / 2013$ & 274.2 & Euthanasia \\
\hline 9 & Trial 5 & $144.2 / 722.4$ & 0747 & $5 / 2 / 2013$ & $6 / 21 / 2013$ & 223.0 & 56 & $6 / 27 / 2013$ & 274.8 & Euthanasia \\
\hline 9 & Trial 5 & $144.2 / 722.4$ & 0773 & $5 / 2 / 2013$ & $6 / 21 / 2013$ & 232.5 & 56 & $6 / 27 / 2013$ & 280.1 & Euthanasia \\
\hline 9 & Trial 5 & $144.2 / 722.4$ & 0775 & $5 / 2 / 2013$ & $6 / 21 / 2013$ & 222.0 & 56 & $6 / 27 / 2013$ & 273.7 & $\mathrm{HCN}$ \\
\hline 9 & Trial 5 & $144.2 / 722.4$ & 0781 & $5 / 2 / 2013$ & $6 / 21 / 2013$ & 230.9 & 56 & $6 / 27 / 2013$ & 285.0 & Euthanasia \\
\hline 9 & Trial 5 & $144.2 / 722.4$ & 0783 & $5 / 2 / 2013$ & 6/21/2013 & 217.7 & 56 & $6 / 27 / 2013$ & 261.7 & Euthanasia \\
\hline
\end{tabular}




\begin{tabular}{|c|c|c|c|c|c|c|c|c|c|c|}
\hline $\begin{array}{l}\text { Profile } \\
(1-11)\end{array}$ & $\begin{array}{c}\text { Trial } \\
\text { Number }\end{array}$ & $\begin{array}{c}\text { Concentration } \\
(\mathrm{ppm})\end{array}$ & $\begin{array}{c}\text { Animal } \\
\#\end{array}$ & $\begin{array}{l}\text { Date of } \\
\text { Birth }\end{array}$ & $\begin{array}{c}\text { Date } \\
\text { Weighed }\end{array}$ & $\begin{array}{c}\text { Random- } \\
\text { ization } \\
\text { Weight (g) }\end{array}$ & $\begin{array}{c}\text { Age at } \\
\text { Exposure } \\
\text { (days) }\end{array}$ & $\begin{array}{c}\text { Date of } \\
\text { Exposure }\end{array}$ & $\begin{array}{c}\text { Weight at } \\
\text { Exposure } \\
\text { (g) }\end{array}$ & Mode of Death \\
\hline 9 & Trial 5 & $144.2 / 722.4$ & 0837 & $5 / 2 / 2013$ & $6 / 21 / 2013$ & 222.7 & 56 & $6 / 27 / 2013$ & 270.9 & Euthanasia \\
\hline 9 & Trial 5 & $144.2 / 722.4$ & 0839 & $5 / 2 / 2013$ & $6 / 21 / 2013$ & 218.2 & 56 & $6 / 27 / 2013$ & 256.3 & Euthanasia \\
\hline 9 & Trial 6 & $187.5 / 934.3$ & 0897 & $5 / 9 / 2013$ & $6 / 28 / 2013$ & 211.5 & 53 & $7 / 1 / 2013$ & 245.8 & $\mathrm{HCN}$ \\
\hline 9 & Trial 6 & $187.5 / 934.3$ & 0899 & $5 / 9 / 2013$ & $6 / 28 / 2013$ & 230.2 & 53 & $7 / 1 / 2013$ & 256.6 & Euthanasia \\
\hline 9 & Trial 6 & $187.5 / 934.3$ & 0901 & $5 / 9 / 2013$ & $6 / 28 / 2013$ & 242.8 & 53 & 7/1/2013 & 268.1 & $\mathrm{HCN}$ \\
\hline 9 & Trial 6 & $187.5 / 934.3$ & 0903 & $5 / 9 / 2013$ & $6 / 28 / 2013$ & 207.8 & 53 & 7/1/2013 & 233.7 & Euthanasia \\
\hline 9 & Trial 6 & $187.5 / 934.3$ & 0905 & $5 / 9 / 2013$ & $6 / 28 / 2013$ & 214.1 & 53 & $7 / 1 / 2013$ & 243.3 & $\mathrm{HCN}$ \\
\hline 9 & Trial 6 & $187.5 / 934.3$ & 0907 & $5 / 9 / 2013$ & $6 / 28 / 2013$ & 242.6 & 53 & $7 / 1 / 2013$ & 274.1 & $\mathrm{HCN}$ \\
\hline 9 & Trial 6 & $187.5 / 934.3$ & 0937 & $5 / 9 / 2013$ & $6 / 28 / 2013$ & 248.6 & 53 & $7 / 1 / 2013$ & 274.9 & $\mathrm{HCN}$ \\
\hline 9 & Trial 6 & $187.5 / 934.3$ & 0939 & $5 / 9 / 2013$ & $6 / 28 / 2013$ & 230.4 & 53 & 7/1/2013 & 259.3 & Euthanasia \\
\hline 9 & Trial 6 & $187.5 / 934.3$ & 0945 & $5 / 9 / 2013$ & $6 / 28 / 2013$ & 229.3 & 53 & $7 / 1 / 2013$ & 257.3 & $\mathrm{HCN}$ \\
\hline 9 & Trial 6 & $187.5 / 934.3$ & 0947 & $5 / 9 / 2013$ & $6 / 28 / 2013$ & 203.0 & 53 & $7 / 1 / 2013$ & 227.9 & Euthanasia \\
\hline 9 & Trial 7 & $150.0 / 731.1$ & 0985 & $6 / 6 / 2013$ & $7 / 26 / 2013$ & 212.6 & 54 & $7 / 30 / 2013$ & 255.1 & $\mathrm{HCN}$ \\
\hline 9 & Trial 7 & $150.0 / 731.1$ & 0987 & 6/6/2013 & $7 / 26 / 2013$ & 225.2 & 54 & $7 / 30 / 2013$ & 248.3 & $\mathrm{HCN}$ \\
\hline 9 & Trial 7 & $150.0 / 731.1$ & 0989 & $6 / 6 / 2013$ & $7 / 26 / 2013$ & 206.5 & 54 & $7 / 30 / 2013$ & 234.3 & $\mathrm{HCN}$ \\
\hline 9 & Trial 7 & $150.0 / 731.1$ & 0991 & $6 / 6 / 2013$ & $7 / 26 / 2013$ & 216.0 & 54 & $7 / 30 / 2013$ & 252.1 & Euthanasia \\
\hline 9 & Trial 7 & $150.0 / 731.1$ & 1001 & 6/6/2013 & $7 / 26 / 2013$ & 213.8 & 54 & $7 / 30 / 2013$ & 253.9 & $\mathrm{HCN}$ \\
\hline 9 & Trial 7 & $150.0 / 731.1$ & 1003 & $6 / 6 / 2013$ & $7 / 26 / 2013$ & 227.0 & 54 & $7 / 30 / 2013$ & 263.6 & Euthanasia \\
\hline 9 & Trial 7 & $150.0 / 731.1$ & 1009 & $6 / 6 / 2013$ & $7 / 26 / 2013$ & 210.0 & 54 & $7 / 30 / 2013$ & 247.1 & $\mathrm{HCN}$ \\
\hline 9 & Trial 7 & $150.0 / 731.1$ & 1011 & $6 / 6 / 2013$ & $7 / 26 / 2013$ & 217.0 & 54 & $7 / 30 / 2013$ & 252.9 & Euthanasia \\
\hline 9 & Trial 7 & $150.0 / 731.1$ & 1061 & $6 / 6 / 2013$ & $7 / 26 / 2013$ & 203.1 & 54 & $7 / 30 / 2013$ & 237.3 & $\mathrm{HCN}$ \\
\hline 9 & Trial 7 & $150.0 / 731.1$ & 1063 & $6 / 6 / 2013$ & $7 / 26 / 2013$ & 231.0 & 54 & $7 / 30 / 2013$ & 269.2 & $\mathrm{HCN}$ \\
\hline 10 & Trial 1 & $133.1 / 677.1$ & 0001 & $4 / 11 / 2013$ & $5 / 31 / 2013$ & 178.3 & 55 & $6 / 5 / 2013$ & 216.1 & Euthanasia \\
\hline 10 & Trial 1 & $133.1 / 677.1$ & 0003 & $4 / 11 / 2013$ & $5 / 31 / 2013$ & 250.3 & 55 & $6 / 5 / 2013$ & 297.8 & Euthanasia \\
\hline 10 & Trial 1 & $133.1 / 677.1$ & 0041 & $4 / 11 / 2013$ & $5 / 31 / 2013$ & 211.6 & 55 & $6 / 5 / 2013$ & 256.0 & Euthanasia \\
\hline 10 & Trial 1 & $133.1 / 677.1$ & 0043 & $4 / 11 / 2013$ & $5 / 31 / 2013$ & 215.1 & 55 & $6 / 5 / 2013$ & 254.8 & $\mathrm{HCN}$ \\
\hline 10 & Trial 1 & $133.1 / 677.1$ & 0153 & $4 / 11 / 2013$ & $5 / 31 / 2013$ & 225.0 & 55 & $6 / 5 / 2013$ & 270.3 & $\mathrm{HCN}$ \\
\hline 10 & Trial 1 & $133.1 / 677.1$ & 0155 & $4 / 11 / 2013$ & $5 / 31 / 2013$ & 177.7 & 55 & 6/5/2013 & 211.9 & Euthanasia \\
\hline
\end{tabular}




\begin{tabular}{|c|c|c|c|c|c|c|c|c|c|c|}
\hline $\begin{array}{l}\text { Profile } \\
(1-11)\end{array}$ & $\begin{array}{c}\text { Trial } \\
\text { Number }\end{array}$ & $\begin{array}{c}\text { Concentration } \\
(\mathrm{ppm})\end{array}$ & $\begin{array}{c}\text { Animal } \\
\#\end{array}$ & $\begin{array}{l}\text { Date of } \\
\text { Birth }\end{array}$ & $\begin{array}{c}\text { Date } \\
\text { Weighed }\end{array}$ & $\begin{array}{c}\text { Random- } \\
\text { ization } \\
\text { Weight }(\mathrm{g})\end{array}$ & $\begin{array}{c}\text { Age at } \\
\text { Exposure } \\
\text { (days) }\end{array}$ & $\begin{array}{c}\text { Date of } \\
\text { Exposure }\end{array}$ & $\begin{array}{c}\text { Weight at } \\
\text { Exposure } \\
\text { (g) }\end{array}$ & Mode of Death \\
\hline 10 & Trial 1 & $133.1 / 677.1$ & 0157 & $4 / 11 / 2013$ & $5 / 31 / 2013$ & 199.1 & 55 & $6 / 5 / 2013$ & 239.3 & Euthanasia \\
\hline 10 & Trial 1 & $133.1 / 677.1$ & 0159 & $4 / 11 / 2013$ & $5 / 31 / 2013$ & 222.2 & 55 & $6 / 5 / 2013$ & 260.8 & $\mathrm{HCN}$ \\
\hline 10 & Trial 1 & $133.1 / 677.1$ & 0169 & $4 / 11 / 2013$ & $5 / 31 / 2013$ & 219.6 & 55 & $6 / 5 / 2013$ & 263.2 & $\mathrm{HCN}$ \\
\hline 10 & Trial 1 & $133.1 / 677.1$ & 0171 & $4 / 11 / 2013$ & $5 / 31 / 2013$ & 196.9 & 55 & $6 / 5 / 2013$ & 242.3 & $\mathrm{HCN}$ \\
\hline 10 & Trial 2 & $176.1 / 869.9$ & 0253 & $4 / 18 / 2013$ & $6 / 7 / 2013$ & 224.4 & 54 & $6 / 11 / 2013$ & 267.4 & $\mathrm{HCN}$ \\
\hline 10 & Trial 2 & $176.1 / 869.9$ & 0255 & $4 / 18 / 2013$ & $6 / 7 / 2013$ & 235.6 & 54 & $6 / 11 / 2013$ & 272.8 & $\mathrm{HCN}$ \\
\hline 10 & Trial 2 & $176.1 / 869.9$ & 0269 & $4 / 18 / 2013$ & $6 / 7 / 2013$ & 217.5 & 54 & $6 / 11 / 2013$ & 252.7 & $\mathrm{HCN}$ \\
\hline 10 & Trial 2 & $176.1 / 869.9$ & 0271 & $4 / 18 / 2013$ & 6/7/2013 & 232.7 & 54 & $6 / 11 / 2013$ & 269.9 & $\mathrm{HCN}$ \\
\hline 10 & Trial 2 & $176.1 / 869.9$ & 0273 & $4 / 18 / 2013$ & 6/7/2013 & 213.0 & 54 & $6 / 11 / 2013$ & 248.7 & $\mathrm{HCN}$ \\
\hline 10 & Trial 2 & $176.1 / 869.9$ & 0275 & $4 / 18 / 2013$ & 6/7/2013 & 243.8 & 54 & $6 / 11 / 2013$ & 281.1 & $\mathrm{HCN}$ \\
\hline 10 & Trial 2 & $176.1 / 869.9$ & 0341 & $4 / 18 / 2013$ & $6 / 7 / 2013$ & 211.6 & 54 & $6 / 11 / 2013$ & 245.3 & $\mathrm{HCN}$ \\
\hline 10 & Trial 2 & $176.1 / 869.9$ & 0343 & $4 / 18 / 2013$ & $6 / 7 / 2013$ & 236.1 & 54 & $6 / 11 / 2013$ & 270.5 & $\mathrm{HCN}$ \\
\hline 10 & Trial 2 & $176.1 / 869.9$ & 0397 & $4 / 18 / 2013$ & 6/7/2013 & 234.5 & 54 & $6 / 11 / 2013$ & 263.9 & $\mathrm{HCN}$ \\
\hline 10 & Trial 2 & $176.1 / 869.9$ & 0399 & $4 / 18 / 2013$ & 6/7/2013 & 211.5 & 54 & $6 / 11 / 2013$ & 235.7 & $\mathrm{HCN}$ \\
\hline 10 & Trial 3 & $108.0 / 544.1$ & 0453 & $4 / 25 / 2013$ & $6 / 14 / 2013$ & 241.1 & 53 & $6 / 17 / 2013$ & 269.9 & Euthanasia \\
\hline 10 & Trial 3 & $108.0 / 544.1$ & 0455 & $4 / 25 / 2013$ & $6 / 14 / 2013$ & 242.0 & 53 & $6 / 17 / 2013$ & 268.1 & Euthanasia \\
\hline 10 & Trial 3 & $108.0 / 544.1$ & 0513 & $4 / 25 / 2013$ & $6 / 14 / 2013$ & 236.6 & 53 & $6 / 17 / 2013$ & 263.3 & $\mathrm{HCN}$ \\
\hline 10 & Trial 3 & $108.0 / 544.1$ & 0515 & $4 / 25 / 2013$ & $6 / 14 / 2013$ & 256.0 & 53 & $6 / 17 / 2013$ & 286.6 & Euthanasia \\
\hline 10 & Trial 3 & $108.0 / 544.1$ & 0529 & $4 / 25 / 2013$ & $6 / 14 / 2013$ & 259.8 & 53 & $6 / 17 / 2013$ & 289.1 & Euthanasia \\
\hline 10 & Trial 3 & $108.0 / 544.1$ & 0531 & $4 / 25 / 2013$ & $6 / 14 / 2013$ & 225.7 & 53 & $6 / 17 / 2013$ & 250.3 & Euthanasia \\
\hline 10 & Trial 3 & $108.0 / 544.1$ & 0537 & $4 / 25 / 2013$ & $6 / 14 / 2013$ & 277.2 & 53 & 6/17/2013 & 320.0 & Euthanasia \\
\hline 10 & Trial 3 & $108.0 / 544.1$ & 0539 & $4 / 25 / 2013$ & $6 / 14 / 2013$ & 230.6 & 53 & $6 / 17 / 2013$ & 260.2 & $\mathrm{HCN}$ \\
\hline 10 & Trial 3 & $108.0 / 544.1$ & 0585 & $4 / 25 / 2013$ & $6 / 14 / 2013$ & 239.4 & 53 & $6 / 17 / 2013$ & 268.4 & $\mathrm{HCN}$ \\
\hline 10 & Trial 3 & $108.0 / 544.1$ & 0587 & $4 / 25 / 2013$ & $6 / 14 / 2013$ & 231.2 & 53 & $6 / 17 / 2013$ & 254.3 & $\mathrm{HCN}$ \\
\hline 10 & Trial 4 & $157.3 / 775.8$ & 0669 & $5 / 2 / 2013$ & $6 / 21 / 2013$ & 240.9 & 54 & $6 / 25 / 2013$ & 275.6 & $\mathrm{HCN}$ \\
\hline 10 & Trial 4 & $157.3 / 775.8$ & 0671 & $5 / 2 / 2013$ & $6 / 21 / 2013$ & 236.0 & 54 & $6 / 25 / 2013$ & 273.3 & $\mathrm{HCN}$ \\
\hline 10 & Trial 4 & $157.3 / 775.8$ & 0813 & $5 / 2 / 2013$ & $6 / 21 / 2013$ & 233.7 & 54 & $6 / 25 / 2013$ & 265.4 & $\mathrm{HCN}$ \\
\hline 10 & Trial 4 & $157.3 / 775.8$ & 0815 & $5 / 2 / 2013$ & $6 / 21 / 2013$ & 237.0 & 54 & $6 / 25 / 2013$ & 277.5 & $\mathrm{HCN}$ \\
\hline
\end{tabular}




\begin{tabular}{|c|c|c|c|c|c|c|c|c|c|c|}
\hline $\begin{array}{l}\text { Profile } \\
(1-11)\end{array}$ & $\begin{array}{c}\text { Trial } \\
\text { Number }\end{array}$ & $\begin{array}{c}\text { Concentration } \\
(\mathrm{ppm})\end{array}$ & $\begin{array}{c}\text { Animal } \\
\#\end{array}$ & $\begin{array}{l}\text { Date of } \\
\text { Birth }\end{array}$ & $\begin{array}{c}\text { Date } \\
\text { Weighed }\end{array}$ & $\begin{array}{c}\text { Random- } \\
\text { ization } \\
\text { Weight }(\mathrm{g})\end{array}$ & $\begin{array}{c}\text { Age at } \\
\text { Exposure } \\
\text { (days) }\end{array}$ & $\begin{array}{c}\text { Date of } \\
\text { Exposure }\end{array}$ & $\begin{array}{c}\text { Weight at } \\
\text { Exposure } \\
\text { (g) }\end{array}$ & Mode of Death \\
\hline 10 & Trial 4 & $157.3 / 775.8$ & 0817 & $5 / 2 / 2013$ & $6 / 21 / 2013$ & 247.7 & 54 & $6 / 25 / 2013$ & 282.9 & $\mathrm{HCN}$ \\
\hline 10 & Trial 4 & $157.3 / 775.8$ & 0819 & $5 / 2 / 2013$ & $6 / 21 / 2013$ & 225.5 & 54 & $6 / 25 / 2013$ & 260.1 & $\mathrm{HCN}$ \\
\hline 10 & Trial 4 & $157.3 / 775.8$ & 0841 & $5 / 2 / 2013$ & $6 / 21 / 2013$ & 242.2 & 54 & $6 / 25 / 2013$ & 276.0 & $\mathrm{HCN}$ \\
\hline 10 & Trial 4 & $157.3 / 775.8$ & 0843 & $5 / 2 / 2013$ & $6 / 21 / 2013$ & 233.6 & 54 & $6 / 25 / 2013$ & 261.9 & $\mathrm{HCN}$ \\
\hline 10 & Trial 4 & $157.3 / 775.8$ & 0849 & $5 / 2 / 2013$ & $6 / 21 / 2013$ & 241.4 & 54 & $6 / 25 / 2013$ & 271.6 & $\begin{array}{c}\mathrm{HCN} \\
\text { (postexposure) }\end{array}$ \\
\hline 10 & Trial 4 & $157.3 / 775.8$ & 0851 & $5 / 2 / 2013$ & $6 / 21 / 2013$ & 238.0 & 54 & $6 / 25 / 2013$ & 276.6 & $\mathrm{HCN}$ \\
\hline 10 & Trial 5 & $95.8 / 479.4$ & 0893 & $5 / 9 / 2013$ & $6 / 28 / 2013$ & 211.4 & 54 & $7 / 2 / 2013$ & 243.4 & Euthanasia \\
\hline 10 & Trial 5 & $95.8 / 479.4$ & 0895 & $5 / 9 / 2013$ & $6 / 28 / 2013$ & 193.0 & 54 & $7 / 2 / 2013$ & 224.0 & $\mathrm{HCN}$ \\
\hline 10 & Trial 5 & $95.8 / 479.4$ & 0929 & $5 / 9 / 2013$ & $6 / 28 / 2013$ & 201.2 & 54 & $7 / 2 / 2013$ & 239.4 & $\mathrm{HCN}$ \\
\hline 10 & Trial 5 & $95.8 / 479.4$ & 0931 & $5 / 9 / 2013$ & $6 / 28 / 2013$ & 219.8 & 54 & $7 / 2 / 2013$ & 256.2 & Euthanasia \\
\hline 10 & Trial 5 & $95.8 / 479.4$ & 0933 & $5 / 9 / 2013$ & $6 / 28 / 2013$ & 201.6 & 54 & $7 / 2 / 2013$ & 236.5 & Euthanasia \\
\hline 10 & Trial 5 & $95.8 / 479.4$ & 0935 & $5 / 9 / 2013$ & $6 / 28 / 2013$ & 213.6 & 54 & $7 / 2 / 2013$ & 249.3 & $\mathrm{HCN}$ \\
\hline 10 & Trial 5 & $95.8 / 479.4$ & 0953 & $5 / 9 / 2013$ & 6/28/2013 & 219.9 & 54 & $7 / 2 / 2013$ & 256.3 & $\mathrm{HCN}$ \\
\hline 10 & Trial 5 & $95.8 / 479.4$ & 0955 & $5 / 9 / 2013$ & $6 / 28 / 2013$ & 203.8 & 54 & $7 / 2 / 2013$ & 229.8 & $\mathrm{HCN}$ \\
\hline 10 & Trial 5 & $95.8 / 479.4$ & 0961 & $5 / 9 / 2013$ & $6 / 28 / 2013$ & 192.0 & 54 & $7 / 2 / 2013$ & 219.3 & $\mathrm{HCN}$ \\
\hline 10 & Trial 5 & $95.8 / 479.4$ & 0963 & $5 / 9 / 2013$ & $6 / 28 / 2013$ & 238.3 & 54 & $7 / 2 / 2013$ & 271.5 & Euthanasia \\
\hline 10 & Trial 6 & $84.3 / 416.3$ & 1065 & $6 / 6 / 2013$ & $7 / 26 / 2013$ & 191.5 & 55 & $7 / 31 / 2013$ & 226.3 & $\mathrm{HCN}$ \\
\hline 10 & Trial 6 & $84.3 / 416.3$ & 1067 & $6 / 6 / 2013$ & $7 / 26 / 2013$ & 209.2 & 55 & $7 / 31 / 2013$ & 249.3 & Euthanasia \\
\hline 10 & Trial 6 & $84.3 / 416.3$ & 1077 & $6 / 6 / 2013$ & $7 / 26 / 2013$ & 204.9 & 55 & $7 / 31 / 2013$ & 241.9 & Euthanasia \\
\hline 10 & Trial 6 & $84.3 / 416.3$ & 1079 & $6 / 6 / 2013$ & $7 / 26 / 2013$ & 204.4 & 55 & $7 / 31 / 2013$ & 250.4 & Euthanasia \\
\hline 10 & Trial 6 & $84.3 / 416.3$ & 1081 & $6 / 6 / 2013$ & $7 / 26 / 2013$ & 200.4 & 55 & $7 / 31 / 2013$ & 245.5 & Euthanasia \\
\hline 10 & Trial 6 & $84.3 / 416.3$ & 1083 & $6 / 6 / 2013$ & $7 / 26 / 2013$ & 221.6 & 55 & $7 / 31 / 2013$ & 265.6 & $\mathrm{HCN}$ \\
\hline 10 & Trial 6 & $84.3 / 416.3$ & 1085 & $6 / 6 / 2013$ & $7 / 26 / 2013$ & 212.0 & 55 & $7 / 31 / 2013$ & 257.5 & Euthanasia \\
\hline 10 & Trial 6 & $84.3 / 416.3$ & 1087 & $6 / 6 / 2013$ & $7 / 26 / 2013$ & 206.4 & 55 & $7 / 31 / 2013$ & 250.8 & Euthanasia \\
\hline 10 & Trial 6 & $84.3 / 416.3$ & 1089 & $6 / 6 / 2013$ & $7 / 26 / 2013$ & 217.1 & 55 & $7 / 31 / 2013$ & 260.4 & $\mathrm{HCN}$ \\
\hline 10 & Trial 6 & $84.3 / 416.3$ & 1091 & $6 / 6 / 2013$ & $7 / 26 / 2013$ & 195.6 & 55 & $7 / 31 / 2013$ & 235.7 & Euthanasia \\
\hline 10 & Trial 7 & $143.1 / 709.2$ & 1145 & $7 / 4 / 2013$ & $8 / 23 / 2013$ & 262.0 & 53 & $8 / 26 / 2013$ & 285.8 & $\mathrm{HCN}$ \\
\hline
\end{tabular}




\begin{tabular}{|c|c|c|c|c|c|c|c|c|c|c|}
\hline $\begin{array}{l}\text { Profile } \\
(1-11)\end{array}$ & $\begin{array}{c}\text { Trial } \\
\text { Number }\end{array}$ & $\begin{array}{c}\text { Concentration } \\
(\mathrm{ppm})\end{array}$ & $\begin{array}{c}\text { Animal } \\
\#\end{array}$ & $\begin{array}{l}\text { Date of } \\
\text { Birth }\end{array}$ & $\begin{array}{c}\text { Date } \\
\text { Weighed }\end{array}$ & $\begin{array}{l}\text { Random- } \\
\text { ization } \\
\text { Weight }(\mathrm{g})\end{array}$ & $\begin{array}{c}\text { Age at } \\
\text { Exposure } \\
\text { (days) }\end{array}$ & $\begin{array}{c}\text { Date of } \\
\text { Exposure }\end{array}$ & $\begin{array}{c}\text { Weight at } \\
\text { Exposure } \\
\text { (g) }\end{array}$ & Mode of Death \\
\hline 10 & Trial 7 & $143.1 / 709.2$ & 1147 & $7 / 4 / 2013$ & $8 / 23 / 2013$ & 253.4 & 53 & $8 / 26 / 2013$ & 278.2 & $\mathrm{HCN}$ \\
\hline 10 & Trial 7 & $143.1 / 709.2$ & 1169 & $7 / 4 / 2013$ & $8 / 23 / 2013$ & 267.5 & 53 & $8 / 26 / 2013$ & 303.1 & $\mathrm{HCN}$ \\
\hline 10 & Trial 7 & $143.1 / 709.2$ & 1171 & $7 / 4 / 2013$ & $8 / 23 / 2013$ & 223.7 & 53 & $8 / 26 / 2013$ & 249.6 & $\mathrm{HCN}$ \\
\hline 10 & Trial 7 & $143.1 / 709.2$ & 1173 & $7 / 4 / 2013$ & $8 / 23 / 2013$ & 231.7 & 53 & $8 / 26 / 2013$ & 258.6 & $\mathrm{HCN}$ \\
\hline 10 & Trial 7 & $143.1 / 709.2$ & 1175 & $7 / 4 / 2013$ & $8 / 23 / 2013$ & 247.0 & 53 & $8 / 26 / 2013$ & 272.3 & $\mathrm{HCN}$ \\
\hline 10 & Trial 7 & $143.1 / 709.2$ & 1181 & $7 / 4 / 2013$ & $8 / 23 / 2013$ & 244.5 & 53 & $8 / 26 / 2013$ & 272.8 & $\mathrm{HCN}$ \\
\hline 10 & Trial 7 & $143.1 / 709.2$ & 1183 & $7 / 4 / 2013$ & $8 / 23 / 2013$ & 227.9 & 53 & $8 / 26 / 2013$ & 257.3 & $\mathrm{HCN}$ \\
\hline 10 & Trial 7 & $143.1 / 709.2$ & 1197 & $7 / 4 / 2013$ & $8 / 23 / 2013$ & 264.5 & 53 & $8 / 26 / 2013$ & 291.4 & $\mathrm{HCN}$ \\
\hline 10 & Trial 7 & $143.1 / 709.2$ & 1199 & $7 / 4 / 2013$ & $8 / 23 / 2013$ & 229.9 & 53 & $8 / 26 / 2013$ & 250.7 & $\mathrm{HCN}$ \\
\hline 10 & Trial 8 & $96.6 / 475.5$ & 1105 & $7 / 4 / 2013$ & $8 / 23 / 2013$ & 232.8 & 55 & $8 / 28 / 2013$ & 269.9 & Euthanasia \\
\hline 10 & Trial 8 & $96.6 / 475.5$ & 1107 & $7 / 4 / 2013$ & $8 / 23 / 2013$ & 223.1 & 55 & $8 / 28 / 2013$ & 259.4 & Euthanasia \\
\hline 10 & Trial 8 & $96.6 / 475.5$ & 1133 & $7 / 4 / 2013$ & $8 / 23 / 2013$ & 202.9 & 55 & $8 / 28 / 2013$ & 241.3 & $\mathrm{HCN}$ \\
\hline 10 & Trial 8 & $96.6 / 475.5$ & 1135 & $7 / 4 / 2013$ & $8 / 23 / 2013$ & 247.5 & 55 & $8 / 28 / 2013$ & 288.5 & $\mathrm{HCN}$ \\
\hline 10 & Trial 8 & $96.6 / 475.5$ & 1157 & $7 / 4 / 2013$ & $8 / 23 / 2013$ & 215.9 & 55 & $8 / 28 / 2013$ & 259.7 & $\mathrm{HCN}$ \\
\hline 10 & Trial 8 & $96.6 / 475.5$ & 1159 & $7 / 4 / 2013$ & $8 / 23 / 2013$ & 231.8 & 55 & $8 / 28 / 2013$ & 273.6 & Euthanasia \\
\hline 10 & Trial 8 & $96.6 / 475.5$ & 1161 & $7 / 4 / 2013$ & $8 / 23 / 2013$ & 223.1 & 55 & $8 / 28 / 2013$ & 278.3 & $\mathrm{HCN}$ \\
\hline 10 & Trial 8 & $96.6 / 475.5$ & 1163 & $7 / 4 / 2013$ & $8 / 23 / 2013$ & 233.7 & 55 & $8 / 28 / 2013$ & 268.6 & $\mathrm{HCN}$ \\
\hline 10 & Trial 8 & $96.6 / 475.5$ & 1165 & $7 / 4 / 2013$ & $8 / 23 / 2013$ & 230.2 & 55 & $8 / 28 / 2013$ & 288.3 & Euthanasia \\
\hline 10 & Trial 8 & $96.6 / 475.5$ & 1167 & $7 / 4 / 2013$ & $8 / 23 / 2013$ & 223.5 & 55 & $8 / 28 / 2013$ & 270.3 & Euthanasia \\
\hline 10 & Trial 9 & $76.8 / 377.5$ & 1109 & $7 / 4 / 2013$ & $8 / 23 / 2013$ & 222.2 & 56 & $8 / 29 / 2013$ & 266.3 & Euthanasia \\
\hline 10 & Trial 9 & $76.8 / 377.5$ & 1111 & $7 / 4 / 2013$ & $8 / 23 / 2013$ & 215.1 & 56 & $8 / 29 / 2013$ & 264.9 & Euthanasia \\
\hline 10 & Trial 9 & $76.8 / 377.5$ & 1117 & $7 / 4 / 2013$ & $8 / 23 / 2013$ & 221.7 & 56 & $8 / 29 / 2013$ & 263.2 & Euthanasia \\
\hline 10 & Trial 9 & $76.8 / 377.5$ & 1119 & $7 / 4 / 2013$ & $8 / 23 / 2013$ & 225.0 & 56 & 8/29/2013 & 277.2 & Euthanasia \\
\hline 10 & Trial 9 & $76.8 / 377.5$ & 1121 & $7 / 4 / 2013$ & $8 / 23 / 2013$ & 209.8 & 56 & $8 / 29 / 2013$ & 259.1 & Euthanasia \\
\hline 10 & Trial 9 & $76.8 / 377.5$ & 1123 & $7 / 4 / 2013$ & $8 / 23 / 2013$ & 236.3 & 56 & $8 / 29 / 2013$ & 286.5 & Euthanasia \\
\hline 10 & Trial 9 & $76.8 / 377.5$ & 1137 & $7 / 4 / 2013$ & $8 / 23 / 2013$ & 212.6 & 56 & $8 / 29 / 2013$ & 261.3 & Euthanasia \\
\hline 10 & Trial 9 & $76.8 / 377.5$ & 1139 & $7 / 4 / 2013$ & $8 / 23 / 2013$ & 231.5 & 56 & $8 / 29 / 2013$ & 282.7 & Euthanasia \\
\hline 10 & Trial 9 & $76.8 / 377.5$ & 1153 & $7 / 4 / 2013$ & $8 / 23 / 2013$ & 193.7 & 56 & $8 / 29 / 2013$ & 239.8 & $\mathrm{HCN}$ \\
\hline
\end{tabular}




\begin{tabular}{|c|c|c|c|c|c|c|c|c|c|c|}
\hline $\begin{array}{l}\text { Profile } \\
(1-11)\end{array}$ & $\begin{array}{c}\text { Trial } \\
\text { Number }\end{array}$ & $\begin{array}{c}\text { Concentration } \\
(\mathrm{ppm})\end{array}$ & $\begin{array}{c}\text { Animal } \\
\#\end{array}$ & $\begin{array}{l}\text { Date of } \\
\text { Birth }\end{array}$ & $\begin{array}{c}\text { Date } \\
\text { Weighed }\end{array}$ & $\begin{array}{c}\text { Random- } \\
\text { ization } \\
\text { Weight }(\mathrm{g})\end{array}$ & $\begin{array}{c}\text { Age at } \\
\text { Exposure } \\
\text { (days) }\end{array}$ & $\begin{array}{c}\text { Date of } \\
\text { Exposure }\end{array}$ & $\begin{array}{c}\text { Weight at } \\
\text { Exposure } \\
(\mathrm{g})\end{array}$ & Mode of Death \\
\hline 10 & Trial 9 & $76.8 / 377.5$ & 1155 & $7 / 4 / 2013$ & $8 / 23 / 2013$ & 235.7 & 56 & $8 / 29 / 2013$ & 274.1 & Euthanasia \\
\hline 11 & Trial 1 & 1239.0 & 0009 & $4 / 11 / 2013$ & $5 / 31 / 2013$ & 225.1 & 53 & $6 / 3 / 2013$ & 243.7 & Euthanasia \\
\hline 11 & Trial 1 & 1239.0 & 0011 & $4 / 11 / 2013$ & $5 / 31 / 2013$ & 247.1 & 53 & $6 / 3 / 2013$ & 266.7 & Euthanasia \\
\hline 11 & Trial 1 & 1239.0 & 0049 & $4 / 11 / 2013$ & $5 / 31 / 2013$ & 218.3 & 53 & $6 / 3 / 2013$ & 233.7 & Euthanasia \\
\hline 11 & Trial 1 & 1239.0 & 0051 & $4 / 11 / 2013$ & $5 / 31 / 2013$ & 263.4 & 53 & $6 / 3 / 2013$ & 296.3 & Euthanasia \\
\hline 11 & Trial 1 & 1239.0 & 0077 & $4 / 11 / 2013$ & $5 / 31 / 2013$ & 239.4 & 53 & $6 / 3 / 2013$ & 266.5 & Euthanasia \\
\hline 11 & Trial 1 & 1239.0 & 0079 & $4 / 11 / 2013$ & $5 / 31 / 2013$ & 216.0 & 53 & $6 / 3 / 2013$ & 241.4 & Euthanasia \\
\hline 11 & Trial 1 & 1239.0 & 0105 & $4 / 11 / 2013$ & $5 / 31 / 2013$ & 243.5 & 53 & $6 / 3 / 2013$ & 264.7 & Euthanasia \\
\hline 11 & Trial 1 & 1239.0 & 0107 & $4 / 11 / 2013$ & $5 / 31 / 2013$ & 207.0 & 53 & $6 / 3 / 2013$ & 232.1 & Euthanasia \\
\hline 11 & Trial 1 & 1239.0 & 0173 & $4 / 11 / 2013$ & $5 / 31 / 2013$ & 252.0 & 53 & $6 / 3 / 2013$ & 279.8 & Euthanasia \\
\hline 11 & Trial 1 & 1239.0 & 0175 & $4 / 11 / 2013$ & $5 / 31 / 2013$ & 209.7 & 53 & $6 / 3 / 2013$ & 238.8 & Euthanasia \\
\hline 11 & Trial 2 & 2528.0 & 0025 & $4 / 11 / 2013$ & $5 / 31 / 2013$ & 222.9 & 54 & $6 / 4 / 2013$ & 254.6 & Euthanasia \\
\hline 11 & Trial 2 & 2528.0 & 0027 & $4 / 11 / 2013$ & $5 / 31 / 2013$ & 210.6 & 54 & $6 / 4 / 2013$ & 243.6 & $\mathrm{HCN}$ \\
\hline 11 & Trial 2 & 2528.0 & 0053 & $4 / 11 / 2013$ & $5 / 31 / 2013$ & 219.2 & 54 & $6 / 4 / 2013$ & 251.6 & $\mathrm{HCN}$ \\
\hline 11 & Trial 2 & 2528.0 & 0055 & $4 / 11 / 2013$ & $5 / 31 / 2013$ & 221.0 & 54 & $6 / 4 / 2013$ & 259.1 & Euthanasia \\
\hline 11 & Trial 2 & 2528.0 & 0081 & $4 / 11 / 2013$ & $5 / 31 / 2013$ & 217.4 & 54 & $6 / 4 / 2013$ & 257.3 & Euthanasia \\
\hline 11 & Trial 2 & 2528.0 & 0083 & $4 / 11 / 2013$ & $5 / 31 / 2013$ & 226.6 & 54 & $6 / 4 / 2013$ & 265.0 & Euthanasia \\
\hline 11 & Trial 2 & 2528.0 & 0185 & $4 / 11 / 2013$ & $5 / 31 / 2013$ & 233.0 & 54 & $6 / 4 / 2013$ & 269.2 & $\mathrm{HCN}$ \\
\hline 11 & Trial 2 & 2528.0 & 0187 & $4 / 11 / 2013$ & $5 / 31 / 2013$ & 214.5 & 54 & $6 / 4 / 2013$ & 246.9 & $\mathrm{HCN}$ \\
\hline 11 & Trial 2 & 2528.0 & 0209 & $4 / 11 / 2013$ & $5 / 31 / 2013$ & 224.6 & 54 & $6 / 4 / 2013$ & 264.9 & $\mathrm{HCN}$ \\
\hline 11 & Trial 2 & 2528.0 & 0211 & $4 / 11 / 2013$ & $5 / 31 / 2013$ & 225.9 & 54 & $6 / 4 / 2013$ & 262.0 & Euthanasia \\
\hline 11 & Trial 3 & 3175.0 & 0449 & $4 / 25 / 2013$ & $6 / 14 / 2013$ & 214.4 & 53 & $6 / 17 / 2013$ & 239.6 & $\mathrm{HCN}$ \\
\hline 11 & Trial 3 & 3175.0 & 0451 & $4 / 25 / 2013$ & $6 / 14 / 2013$ & 268.7 & 53 & $6 / 17 / 2013$ & 304.4 & $\mathrm{HCN}$ \\
\hline 11 & Trial 3 & 3175.0 & 0525 & $4 / 25 / 2013$ & $6 / 14 / 2013$ & 248.1 & 53 & $6 / 17 / 2013$ & 279.8 & $\mathrm{HCN}$ \\
\hline 11 & Trial 3 & 3175.0 & 0527 & $4 / 25 / 2013$ & $6 / 14 / 2013$ & 247.5 & 53 & $6 / 17 / 2013$ & 278.9 & $\mathrm{HCN}$ \\
\hline 11 & Trial 3 & 3175.0 & 0625 & $4 / 25 / 2013$ & $6 / 14 / 2013$ & 243.0 & 53 & $6 / 17 / 2013$ & 273.8 & $\mathrm{HCN}$ \\
\hline 11 & Trial 3 & 3175.0 & 0627 & $4 / 25 / 2013$ & $6 / 14 / 2013$ & 231.2 & 53 & $6 / 17 / 2013$ & 256.5 & $\mathrm{HCN}$ \\
\hline 11 & Trial 3 & 3175.0 & 0633 & $4 / 25 / 2013$ & $6 / 14 / 2013$ & 239.9 & 53 & $6 / 17 / 2013$ & 270.6 & $\mathrm{HCN}$ \\
\hline
\end{tabular}




\begin{tabular}{|c|c|c|c|c|c|c|c|c|c|c|}
\hline $\begin{array}{l}\text { Profile } \\
(1-11)\end{array}$ & $\begin{array}{c}\text { Trial } \\
\text { Number }\end{array}$ & $\begin{array}{c}\text { Concentration } \\
(\mathrm{ppm})\end{array}$ & $\begin{array}{c}\text { Animal } \\
\#\end{array}$ & $\begin{array}{l}\text { Date of } \\
\text { Birth }\end{array}$ & $\begin{array}{c}\text { Date } \\
\text { Weighed }\end{array}$ & $\begin{array}{c}\text { Random- } \\
\text { ization } \\
\text { Weight }(\mathrm{g})\end{array}$ & $\begin{array}{c}\text { Age at } \\
\text { Exposure } \\
\text { (days) }\end{array}$ & $\begin{array}{c}\text { Date of } \\
\text { Exposure }\end{array}$ & $\begin{array}{c}\text { Weight at } \\
\text { Exposure } \\
(\mathrm{g})\end{array}$ & Mode of Death \\
\hline 11 & Trial 3 & 3175.0 & 0635 & $4 / 25 / 2013$ & $6 / 14 / 2013$ & 246.2 & 53 & $6 / 17 / 2013$ & 277.1 & $\mathrm{HCN}$ \\
\hline 11 & Trial 3 & 3175.0 & 0637 & $4 / 25 / 2013$ & $6 / 14 / 2013$ & 251.4 & 53 & $6 / 17 / 2013$ & 284.5 & $\mathrm{HCN}$ \\
\hline 11 & Trial 3 & 3175.0 & 0639 & $4 / 25 / 2013$ & $6 / 14 / 2013$ & 268.1 & 53 & $6 / 17 / 2013$ & 301.5 & $\mathrm{HCN}$ \\
\hline 11 & Trial 4 & 2202.5 & 0477 & $4 / 25 / 2013$ & $6 / 14 / 2013$ & 209.5 & 56 & $6 / 20 / 2013$ & 262.8 & Euthanasia \\
\hline 11 & Trial 4 & 2202.5 & 0479 & $4 / 25 / 2013$ & $6 / 14 / 2013$ & 230.0 & 56 & $6 / 20 / 2013$ & 294.1 & $\mathrm{HCN}$ \\
\hline 11 & Trial 4 & 2202.5 & 0485 & $4 / 25 / 2013$ & $6 / 14 / 2013$ & 228.2 & 56 & $6 / 20 / 2013$ & 285.4 & Euthanasia \\
\hline 11 & Trial 4 & 2202.5 & 0487 & $4 / 25 / 2013$ & $6 / 14 / 2013$ & 216.2 & 56 & $6 / 20 / 2013$ & 265.3 & $\mathrm{HCN}$ \\
\hline 11 & Trial 4 & 2202.5 & 0609 & $4 / 25 / 2013$ & $6 / 14 / 2013$ & 229.1 & 56 & $6 / 20 / 2013$ & 284.9 & Euthanasia \\
\hline 11 & Trial 4 & 2202.5 & 0611 & $4 / 25 / 2013$ & $6 / 14 / 2013$ & 188.4 & 56 & $6 / 20 / 2013$ & 226.6 & $\mathrm{HCN}$ \\
\hline 11 & Trial 4 & 2202.5 & 0641 & $4 / 25 / 2013$ & $6 / 14 / 2013$ & 216.0 & 56 & $6 / 20 / 2013$ & 277.5 & $\mathrm{HCN}$ \\
\hline 11 & Trial 4 & 2202.5 & 0643 & $4 / 25 / 2013$ & $6 / 14 / 2013$ & 208.7 & 56 & $6 / 20 / 2013$ & 260.8 & $\mathrm{HCN}$ \\
\hline 11 & Trial 4 & 2202.5 & 0649 & $4 / 25 / 2013$ & $6 / 14 / 2013$ & 205.8 & 56 & $6 / 20 / 2013$ & 254.2 & $\mathrm{HCN}$ \\
\hline 11 & Trial 4 & 2202.5 & 0651 & $4 / 25 / 2013$ & $6 / 14 / 2013$ & 236.3 & 56 & $6 / 20 / 2013$ & 299.5 & $\mathrm{HCN}$ \\
\hline 11 & Trial 5 & 1793.2 & 0713 & $5 / 2 / 2013$ & $6 / 21 / 2013$ & 236.8 & 54 & $6 / 25 / 2013$ & 275.7 & Euthanasia \\
\hline 11 & Trial 5 & 1793.2 & 0715 & $5 / 2 / 2013$ & $6 / 21 / 2013$ & 238.1 & 54 & $6 / 25 / 2013$ & 271.3 & $\mathrm{HCN}$ \\
\hline 11 & Trial 5 & 1793.2 & 0753 & $5 / 2 / 2013$ & $6 / 21 / 2013$ & 251.7 & 54 & $6 / 25 / 2013$ & 286.1 & $\begin{array}{c}\mathrm{HCN} \\
\text { (postexposure) }\end{array}$ \\
\hline 11 & Trial 5 & 1793.2 & 0755 & $5 / 2 / 2013$ & $6 / 21 / 2013$ & 227.7 & 54 & $6 / 25 / 2013$ & 261.4 & Euthanasia \\
\hline 11 & Trial 5 & 1793.2 & 0785 & $5 / 2 / 2013$ & 6/21/2013 & 235.5 & 54 & $6 / 25 / 2013$ & 268.9 & $\mathrm{HCN}$ \\
\hline 11 & Trial 5 & 1793.2 & 0787 & $5 / 2 / 2013$ & $6 / 21 / 2013$ & 242.9 & 54 & $6 / 25 / 2013$ & 281.3 & Euthanasia \\
\hline 11 & Trial 5 & 1793.2 & 0853 & $5 / 2 / 2013$ & $6 / 21 / 2013$ & 238.6 & 54 & $6 / 25 / 2013$ & 277.2 & Euthanasia \\
\hline 11 & Trial 5 & 1793.2 & 0855 & $5 / 2 / 2013$ & $6 / 21 / 2013$ & 232.2 & 54 & $6 / 25 / 2013$ & 264.0 & $\mathrm{HCN}$ \\
\hline 11 & Trial 5 & 1793.2 & 0857 & $5 / 2 / 2013$ & $6 / 21 / 2013$ & 225.5 & 54 & $6 / 25 / 2013$ & 251.9 & Euthanasia \\
\hline 11 & Trial 5 & 1793.2 & 0859 & $5 / 2 / 2013$ & $6 / 21 / 2013$ & 250.6 & 54 & $6 / 25 / 2013$ & 286.5 & Euthanasia \\
\hline 11 & Trial 6 & 2186.3 & 0889 & $5 / 9 / 2013$ & $6 / 28 / 2013$ & 201.6 & 54 & 7/2/2013 & 233.0 & $\mathrm{HCN}$ \\
\hline 11 & Trial 6 & 2186.3 & 0891 & $5 / 9 / 2013$ & $6 / 28 / 2013$ & 194.3 & 54 & $7 / 2 / 2013$ & 226.9 & $\mathrm{HCN}$ \\
\hline 11 & Trial 6 & 2186.3 & 0913 & $5 / 9 / 2013$ & $6 / 28 / 2013$ & 203.5 & 54 & $7 / 2 / 2013$ & 235.3 & $\mathrm{HCN}$ \\
\hline 11 & Trial 6 & 2186.3 & 0915 & $5 / 9 / 2013$ & 6/28/2013 & 205.4 & 54 & $7 / 2 / 2013$ & 241.3 & $\mathrm{HCN}$ \\
\hline
\end{tabular}




\begin{tabular}{|c|c|c|c|c|c|c|c|c|c|c|}
\hline $\begin{array}{l}\text { Profile } \\
(1-11)\end{array}$ & $\begin{array}{c}\text { Trial } \\
\text { Number }\end{array}$ & $\begin{array}{l}\text { Concentration } \\
(\mathrm{ppm})\end{array}$ & $\begin{array}{c}\text { Animal } \\
\#\end{array}$ & $\begin{array}{l}\text { Date of } \\
\text { Birth }\end{array}$ & $\begin{array}{c}\text { Date } \\
\text { Weighed }\end{array}$ & $\begin{array}{l}\text { Random- } \\
\text { ization } \\
\text { Weight (g) }\end{array}$ & $\begin{array}{c}\text { Age at } \\
\text { Exposure } \\
\text { (days) }\end{array}$ & $\begin{array}{c}\text { Date of } \\
\text { Exposure }\end{array}$ & $\begin{array}{c}\text { Weight at } \\
\text { Exposure } \\
(\mathrm{g})\end{array}$ & Mode of Death \\
\hline 11 & Trial 6 & 2186.3 & 0921 & $5 / 9 / 2013$ & $6 / 28 / 2013$ & 207.5 & 54 & $7 / 2 / 2013$ & 242.1 & $\mathrm{HCN}$ \\
\hline 11 & Trial 6 & 2186.3 & 0923 & $5 / 9 / 2013$ & $6 / 28 / 2013$ & 214.7 & 54 & $7 / 2 / 2013$ & 250.8 & Euthanasia \\
\hline 11 & Trial 6 & 2186.3 & 0925 & $5 / 9 / 2013$ & $6 / 28 / 2013$ & 230.3 & 54 & $7 / 2 / 2013$ & 263.1 & $\mathrm{HCN}$ \\
\hline 11 & Trial 6 & 2186.3 & 0927 & $5 / 9 / 2013$ & $6 / 28 / 2013$ & 199.6 & 54 & $7 / 2 / 2013$ & 230.2 & $\mathrm{HCN}$ \\
\hline 11 & Trial 6 & 2186.3 & 0965 & $5 / 9 / 2013$ & $6 / 28 / 2013$ & 206.7 & 54 & $7 / 2 / 2013$ & 246.9 & $\mathrm{HCN}$ \\
\hline 11 & Trial 6 & 2186.3 & 0967 & $5 / 9 / 2013$ & $6 / 28 / 2013$ & 214.3 & 54 & $7 / 2 / 2013$ & 258.4 & $\mathrm{HCN}$ \\
\hline 11 & Trial 7 & 1597.5 & 1013 & $6 / 6 / 2013$ & $7 / 26 / 2013$ & 210.8 & 54 & $7 / 30 / 2013$ & 241.3 & Euthanasia \\
\hline 11 & Trial 7 & 1597.5 & 1015 & 6/6/2013 & $7 / 26 / 2013$ & 217.3 & 54 & $7 / 30 / 2013$ & 246.5 & Euthanasia \\
\hline 11 & Trial 7 & 1597.5 & 1017 & $6 / 6 / 2013$ & $7 / 26 / 2013$ & 200.7 & 54 & $7 / 30 / 2013$ & 233.2 & Euthanasia \\
\hline 11 & Trial 7 & 1597.5 & 1019 & 6/6/2013 & $7 / 26 / 2013$ & 222.0 & 54 & $7 / 30 / 2013$ & 259.3 & Euthanasia \\
\hline 11 & Trial 7 & 1597.5 & 1049 & 6/6/2013 & $7 / 26 / 2013$ & 221.9 & 54 & $7 / 30 / 2013$ & 260.6 & Euthanasia \\
\hline 11 & Trial 7 & 1597.5 & 1051 & 6/6/2013 & $7 / 26 / 2013$ & 217.9 & 54 & $7 / 30 / 2013$ & 254.8 & Euthanasia \\
\hline 11 & Trial 7 & 1597.5 & 1053 & $6 / 6 / 2013$ & $7 / 26 / 2013$ & 228.0 & 54 & $7 / 30 / 2013$ & 266.3 & Euthanasia \\
\hline 11 & Trial 7 & 1597.5 & 1055 & $6 / 6 / 2013$ & $7 / 26 / 2013$ & 215.4 & 54 & $7 / 30 / 2013$ & 246.7 & $\mathrm{HCN}$ \\
\hline 11 & Trial 7 & 1597.5 & 1093 & 6/6/2013 & $7 / 26 / 2013$ & 225.2 & 54 & $7 / 30 / 2013$ & 268.6 & Euthanasia \\
\hline 11 & Trial 7 & 1597.5 & 1095 & $6 / 6 / 2013$ & $7 / 26 / 2013$ & 210.9 & 54 & $7 / 30 / 2013$ & 247.0 & Euthanasia \\
\hline
\end{tabular}

${ }^{\mathrm{a}}$ Animal 0309 (Profile 9, Trial 1) died following the 24 hour post-observation period, cause of death undetermined. 
Table S-3. Animal Body Weights and Ages at Exposure (Mean \pm standard deviation, range; 10 rats per trial)

\begin{tabular}{|c|c|c|c|c|}
\hline Profile & $\begin{array}{l}\text { Number } \\
\text { of Trials }\end{array}$ & $\begin{array}{l}\text { Body weight (by } \\
\text { individual) (g) }\end{array}$ & $\begin{array}{c}\text { Body weight (by } \\
\text { trial mean) }(g)\end{array}$ & Age at exposure (Days) \\
\hline 1 & 5 & $\begin{array}{c}263.4 \pm 16.5 \\
(212.5-300.6)\end{array}$ & $\begin{array}{c}263.3 \pm 9.3 \\
(254.7-275.3)\end{array}$ & $53.6 \pm 0.5(53-54)$ \\
\hline 2 & 4 & $\begin{array}{c}269.7 \pm 12.8 \\
(246.2-297.3)\end{array}$ & $\begin{array}{c}269.6 \pm 6.2 \\
(261.2-274.6)\end{array}$ & $54.3 \pm 1.3(53-56)$ \\
\hline 3 & 4 & $\begin{array}{c}265.1 \pm 17.2 \\
(220.6-292.3)\end{array}$ & $\begin{array}{c}265.1 \pm 10.2 \\
(253.1-276.9)\end{array}$ & $54.8 \pm 0.4(54-55)$ \\
\hline 4 & 8 & $\begin{array}{c}257.8 \pm 17.7 \\
(211.8-294.4)\end{array}$ & $\begin{array}{c}257.9 \pm 9.6 \\
(243.7-271.6)\end{array}$ & $54.1 \pm 1.1(53-56)$ \\
\hline 5 & 4 & $\begin{array}{c}266.0 \pm 16.5 \\
(212.7-291.5)\end{array}$ & $\begin{array}{c}266.0 \pm 10.2 \\
(253.6-276.9)\end{array}$ & $54.0 \pm 1.0(53-55)$ \\
\hline 6 & 2 & $\begin{array}{c}260.5 \pm 14.5 \\
(227.0-281.5)\end{array}$ & $\begin{array}{c}260.5 \pm 2.2 \\
(258.9-262.0)\end{array}$ & $54.0 \pm 1.0(53-55)$ \\
\hline 7 & 6 & $\begin{array}{c}265.5 \pm 18.0 \\
(219.7-303.6)\end{array}$ & $\begin{array}{c}265.5 \pm 14.0 \\
(245.7-279.0)\end{array}$ & $54.7 \pm 1.3(53-56)$ \\
\hline 8 & 4 & $\begin{array}{c}265.5 \pm 13.8 \\
(237.1-297.7)\end{array}$ & $\begin{array}{c}265.5 \pm 10.5 \\
(253.2-277.8)\end{array}$ & $54.3 \pm 0.4(54-55)$ \\
\hline 9 & 7 & $\begin{array}{c}264.0 \pm 13.9 \\
(227.9-294.5)\end{array}$ & $\begin{array}{c}264.0 \pm 9.1 \\
(251.4-274.7)\end{array}$ & $54.4 \pm 1.4(53-56)$ \\
\hline 10 & 9 & $\begin{array}{c}261.9 \pm 19.2 \\
(211.9-320.0)\end{array}$ & $\begin{array}{c}261.9 \pm 11.7 \\
(242.6-273.0)\end{array}$ & $54.3 \pm 0.9(53-56)$ \\
\hline 11 & 7 & $\begin{array}{c}261.3 \pm 19.1 \\
(226.6-304.4)\end{array}$ & $\begin{array}{c}261.3 \pm 12.4 \\
(242.8-276.7)\end{array}$ & $54.0 \pm 0.9(53-56)$ \\
\hline
\end{tabular}

